UNIVERSIDADE DE SÃO PAUULO

GACULDADE DE FILOSOFIA, CIÊNCIAS E LETRAS.

\title{
Foraminíferos Miocênicos
}

da

\section{Formação Pirabas}
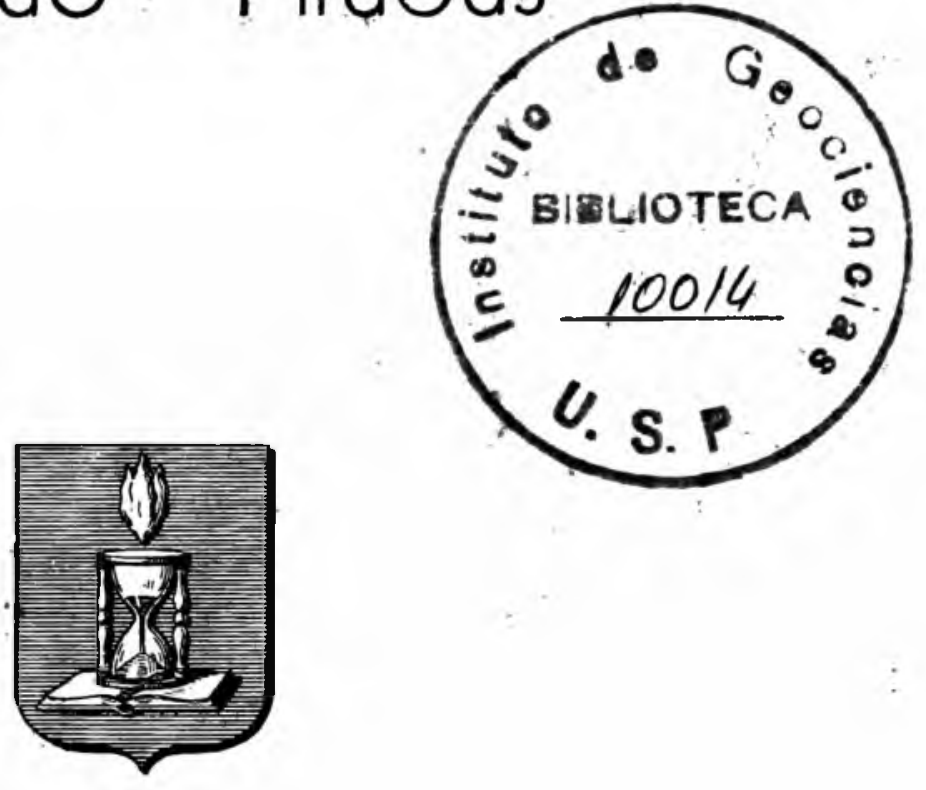
Os Boletins da Faculdade de Filosafia, Ciências e Letras da Universidade de São Paulo, são editados pelos Departamentos das suas diversas secções.

Tôda correspondência deverá ser dirigida para o Departamento respectivo da Faculdade de Filosofia, Ciências e Letras - Cäixa Postal 8.105, São Paulo, Brasil.

The "Boletins da. Faculdade - de Filosofia, Ciências. e Letras da Universidade de Sã̃o Paulo" are edited by the different Departments of the Faculty.

All correspondence should be addressed to the Department concerned, Caixa Postal 8.105, São Paulo, Brasil.

UNIVERSIDADE DE SÃO PAUTLO

Reitor: - Prof. Dr. Gabriel Teixeira de Carvalho

FACULDADE DE FILOSOFLA, CIENCIAS E LETRAS .

Diretor: Prof., Dr. Eurípedes Simões de Paula

Secretário: Lic. Odilon Nogueira de Mattos

DEPARTAMENTO DE GEOLOGIA E PALEONTOLOGIA

Diretor :

Prof Viktor Leinz,"Ph. D.

Professor Cooperador:

Josué Camargo Mendes (Liv. Doc.)

Livre Docente:

Ruy Ozório de Freitas, D. Sc.

Assistentes :

Setembrino Petri, D. Sc.

Sérgio Estanislau de Amaral, D. Sc.

Reinholt Ellert, Lic. Sc.

Alfredo $J$ Simon Biornberg, Lic. Sc.

Auxiliares do Ensino

Ana Maria Vieira de Carvalho, Lic. Sc.

Roberto de Freitas 
UNIVERSIDADE DE SÃO PAULO

FACULDADE DE FILOSOFIA, CIÊNCIAS E LETRAS

S E T E M B R I N O P E T R I

\section{Foramıníferos Miocênıcos}

da

\section{Formação Pirabas}

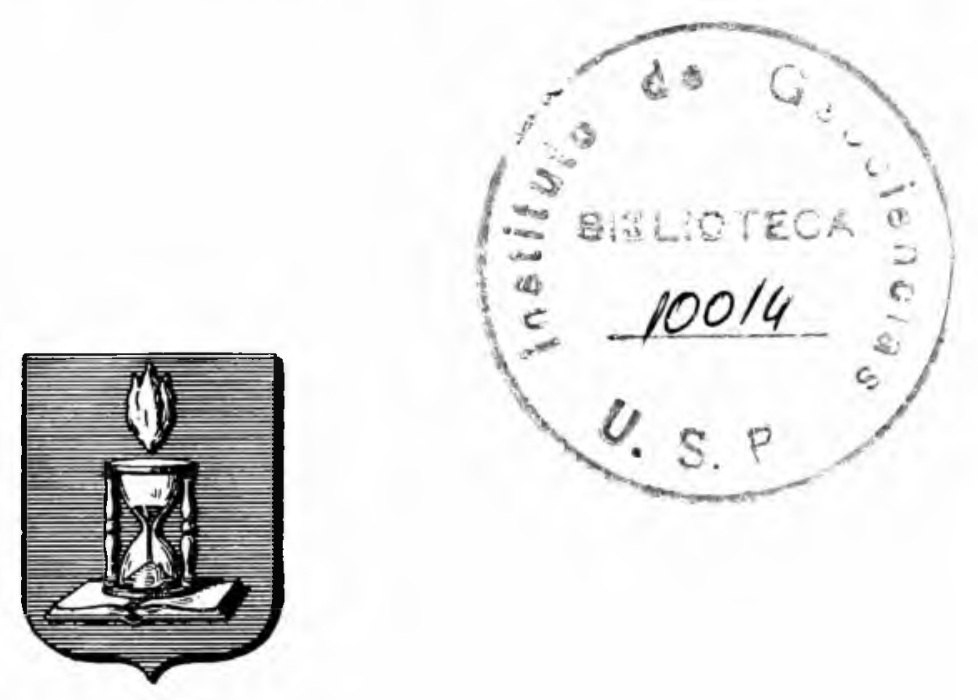


Êste boletim foi impresso com o auxílio do Conselho Nacional de Pesquisas 
SUMMARY

HISTÓRICO

GEOLOGIA

IDADE DA FAUNA 8

ECOLOGIA 10

CORRELAÇÕES COM FAUNAS MIOCENICAS DA AMËRICA TROPICAL 16

AFLORAMENTOS E DISTRIBUIÇÃO DOS FORAMINÍ-

FEROS

JESCRIÇÃO DAS ESPÉCIES 27

BIBLIOGRAFIA $\quad 77$

EXPLICAÇÃO DAS ESTAMPAS 



\section{I - SUMMARY}

In the present paper are deseribed Brazilian fossil Foraminifera from limestones of the Pirabas formation, lower Miocene. The foraminiferal fauna like the Mollusea described by Maury (1924) shows grant endemism, so several new species are described.

The Pirabas basin is located in the state of Pará near the coast northeast of the city of Belem oceupying an area about $80 \mathrm{~km}$ in the coast in the direction $\mathrm{E}-\mathrm{W}$ by about $90 \mathrm{~km}$ from the coast to the interior in the direction N-S (See map) It is characterized by outcrops of marine Miocene sediments known as Pirabas formation in the vallers, beeing corered in the divides by continental sediments possibly Pliocene known as Parreiras formation. Outerops of Pirabas formation can be found along the coast from Marapanim river to Quatipuru river and to the interior beyond the Bragança railway reaching the divide between rivers which run to ocean and the Guamá river. The Pirabas formation is covered westward by the Barreiras formation. It is limited eastward by outcrops of cristaline rocks (granite and pegmatite); northward the formation may possibly be found in the continental shelf and southward beyond the divide referrel to above the formation does not exist due either to erosion inasmuch as the beds lip slightly (about $82 \mathrm{~cm}: \mathrm{km}$ ) northward or it was never present because the border of the basin would be located there. We favor this last hypothesis.

Contacts between the Pirabas formation and beds underneath are not known, so we do not know the thickness of this formation. In the coast the formation outerops in the tide zone and in the interior we find only seattered spots in the regolith. Contacts between Pirabas and Barreiras formation are found sometimes. The thickest outerops of the Pirabas formation knowis so iar are around $t \mathrm{~m}$. In the Tauari region we find eristaline rocks $12 \mathrm{~m}$ below outerop $11 . .^{\circ} 15$ of the Pirabas formation so this formation is not thick at least in this area. In Maracanã, in the Pirahas basin. geophysical researches revealed the presence of probably 1.000 m of sediments. As the surface is occupied by miocene beds of the I'irabas formation this enormous thickness of sediments is formed by older rocks. possibly the equivalent of the Eocene and Cretaceous of the northeastern region of Brazil.

Several ecological resulto were acquired by the study of the foraminiferal fauna. The enviromment inferred for the deposition of the forma- 
tion is marine, shallow clear warm waters and free communication with the ocean because of the relatively common presence of planktonic foraminifera. The outerops can be grouped into three different facies: the first one shows evidences of deposition in normal saline shallow water environment (possibly less than $30 \mathrm{~m}$ deep) and is characterized by abundant miliolids, several species of Elphidium, Archaias and Amphistegina. This facies is here called Castelo. The second shows evidences of deposition in a shallower environment with perhaps a salinity somewhat below normal (depth possibly 2 to $9 \mathrm{~m}$ ). It is characterized by the species Streblus catesbyanus (d'Orbigny) var. tepida (Cushman). This facies is here called Canecos. The third is represented by a dark gray thin bedded limestone with abundant concretions. Almost every concretion has either dycotiledoneous leaves or a small crab. This limestone probably represents a mangrove environment. It is called here Baunilha facies.

The environments inferred are concordant with the geographical distribution of the outcrops, the normal marine environment represented by onterops localized in the coast far from the border of the basin and the shallower enviromments represented by outcrops localized in the interior or in the coast but near the border of the basin. The original basin therefore possibly did not extend far beyond the present limit in the southern and eastern directions.

The percentages of species of the Pirabas formation found in other formations of Tropical America is shown in Table 2. The greatest values belong to formations deposited in shallow water environment.

The extensive rleposition of limestone almost pure and the absence of clastics suggest a rather low region without elevations. That terrigenous material could be transported is proved by the presence of bone fragments of terrestrial vertebrates as for instance in .Taperica outcrop.

The age of the fatma should be considered Upper Cenozoic. We faror the Miocene age. The reasons for this assignment are the following: 1) Most of the described species have their geological range restricted to the Miocene - Recent interval. Few species go down to the Lower Tertiary. 2) Our fauna is very similar to the Cururu fauna, Marajó Island, Brazil. where there are characteristic Miocene index fossils, among them Orbulina suturalis Bronnimann and Globoquadrina quadraria (Cushman and Ellisor) (Petri, 1954). 3) We have found in the Prabas fama, the species Oolina nuttalli (Galloway and Heminway) which is very characteristic and restricted to the West India Oligocene and Miocene. The species Conorbella americana Petri, sp. nor. is similax and possibly identical to the form described by Bermulez (1949, p. 240) from the 8 . Domingos Miocene as Discorbis "f. patellifu"mis (Brady). The species "Discorbis patelliformis (Brady)" is found in the Pacific Ocean. It is not found in the Atlantic Ocean. 4) Manry (1921, p. 43-45), studying the Pirabas ma- 
crofauna considered it as Lower Miocene because of the gastropod genus Orthaulax restricted to this epoch.

The species of the Pirabas formation found in other regions of the Tropical America Miocene are placed in table 1. Comparisons were made with the Miocene of the following countries: - Colombia, Venezuela, 'Trinidad, Jamaica, Cuba, Puerto Rico, Haiti and S. Domingos.

Table 3 shows the distribution of the species of Foraminifera in the witerops studied. Outerops n. 1, 2, 3, 4, 5, 6, 7, 8, 9, 17 and 19 belong to the Castelo facies. Outcrops n. 10, 15, 21, and 23 to the Canecos facies. Onterop 11 (Baunilha facies) is grouped with the Canecos facies because of the similarity of Foraminifera. The outcrops can be localized by their numbers in the map of the p. 5 .

The species described are the following:

1) Lmphistegina lessonii d'Orbigny

2) Angulogerina hughesi (Galloway and Wissler)

3) A. paraensis Petri, sp. nov.

4) Archaias angulata (Fichtel and Moll)

5) Articulina ? sp.

6) Bolivina pirabensis Petri. sp. nov.

7) B. plicatella (Cushman)

8) B. tortuosa Brady

9) $B . \mathrm{sp}$.

10) Buliminella sp.

11) Cassidulina laevigata d'Orbigny

12) Cibicides lobatulus (Walker and Jacob)

13) C. pirabensis Petri, sp. nov.

14) C. pseudoungerianus (Cushman)

15) Cibicidina paraensis Petri, sp. nov.

16) Conorbella americana Petri, sp. nov.

17) Darbyella? sp.

18) Dentalina aff. consobrina d'Orbigny

19) D. sp.

20) Discopulvinulina pirabensis Petri. sp. nov.

21) Discorbis paraensis Petri, sp. nov.

22) D. ? sp.

23) Elphidium poeyanum (d'Orbigny)

24.) E. sagrai (d'Orbigny) var. cururuensis Petri

25) E. sp.

26) Eponides repandus (Fichtel and Moll)

27) E. ? sp.

28) Fissurina depressula Petri, sp. nov.

29) F lnevigata Reuss 
30) Globigerina bulloides d'Orbigny

31) G. sp.

32) G. ? sp.

33) Globigerinoides triloba (Reuss)

34) Globorotalia cf. menardii (d'Orbigny)

35) Globulina tropicale Petri, sp. nov.

36) Guttulina irregularis (d'Orbigny)

37) Haplophragmoides sp.

38) Lagena bulloides Petri, sp. nov.

39) L. cf. perlucida (Montagu)

40) L. cf. substriata Williamson

41) L. sp.

42) Marginulina? sp.

43) Neoconorbina terquemi (Rzehak)

44) Nodosaria sp.

45) Nonion canecensis Petri, sp. nov.

46) Nonionella pirabensis Petri, sp. nov.

47) Oolina nuttalli (Galloway and Heminway)

48) Operculina sp.

49) Parafissurina? hemisphaerica Petri, sp. nov.

50) Planulina. sp.

51) Polymorphina sp.

52) Pseudobulimina? sp.

53) Pseudopolymorphina tropicale Petri. sp. nov.

54) Pyrgo subsphaerica (d'Orbigny)

55) $P$. sp.

56) Quinqueloculina fusiformis Petri, sp. nov

57) Q. lamarckiana d'Orbigny

58) Q. seminula (Linné)

59) $Q$. sp.

60) Siphonina pulchra Cushman

61) Spirillina ef. vivipara Ehrenberg

62) Spiroplectammina japericensis Petri, sp. nov.

63) Streblus beccarii (Linné) var. mendesi Petri

64) S. catesbyanus (d' Orbigny) var. tepida (Cushman)

65) Textularia japericensis Petri, sp. nov.

66) Triloculina oblonga (Montagu)

67) T. sp.

68) Trochammina japericensis Petri, sp. nov.

69) T. sp.

i). Turborotalia ? -p. 


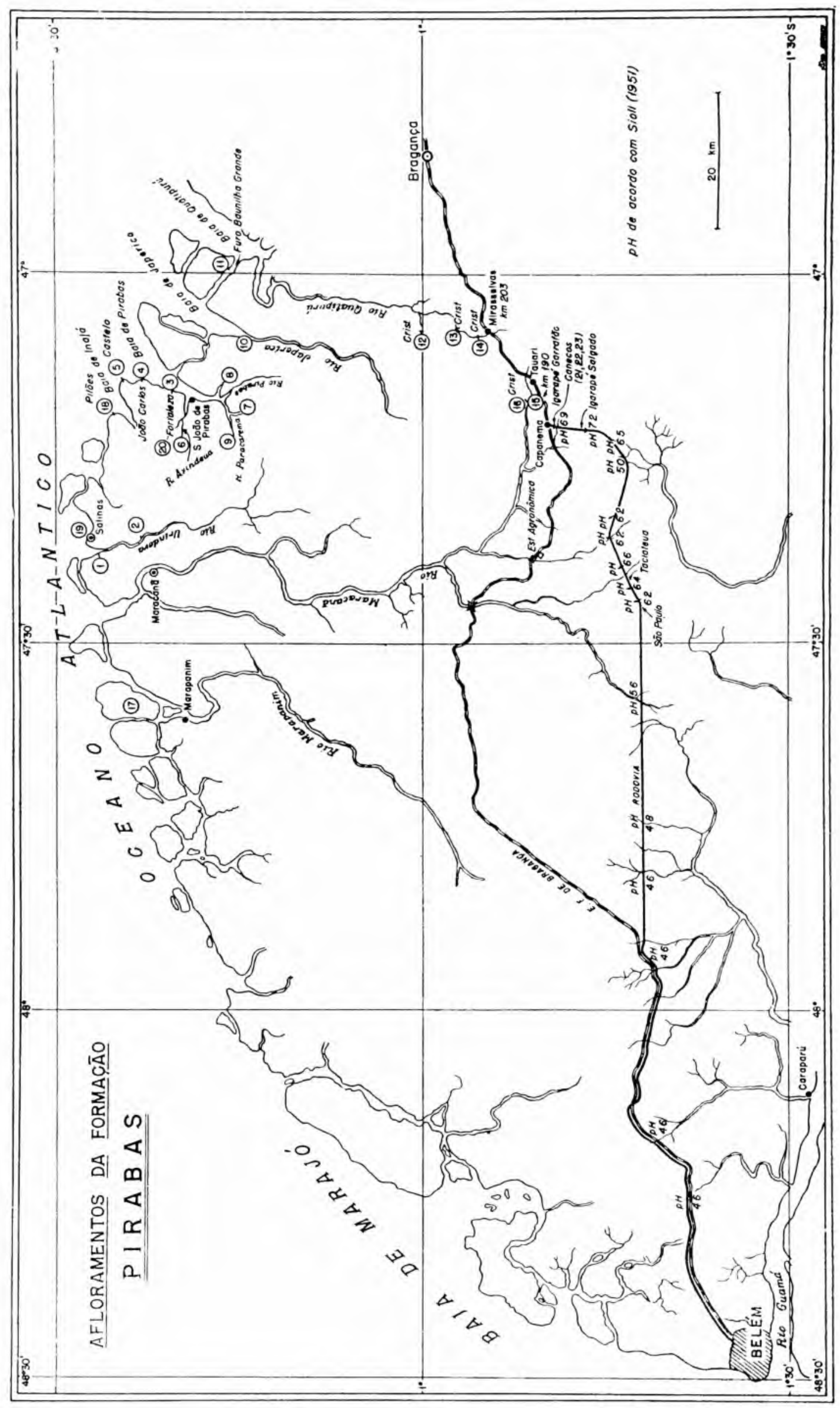




\section{II - HISTóRICO}

Ferreira Penna em 1876 coletou, pela primeira vez, fósseis da formação Pirabas os quais foram deseritos por Charles White (1887) que os considerou como cretácicos. Contudo êste autor tinha a mão fauna restrita. Autores posteriores, até 1913, sempre consideraram a fauna como cretácica, embora alguns notassem semelhanças com faunas do Ter(iário. Em 1913, Maury (1924, p. 36) examinando fósseis coletados pelo então Serviço Geológico e Mineralógico do Brasil (hoje Divisão de Geologia e Mineralogia), concluiu pela idade terciária para a formação Pirabas. Williams (Em Maury idem, idem) mapeou êsses sedimentos como eocênicos, correlacionando-os com a formação Maria Farinha de Pernambuco. Também Branner (1919, p. 96) aceitou a idade eocênica para a formação. Em 1918 Maury (Tlem, idem) referiu a fauna ao Miocêno Inferior. Em 1919 e 1920 Carvalho (1926, p. 115) ampliou muito a área conhecida da formação. Em 1924 Maurỵ, tendo à mão abundante material, descreveu os moluscos (e dois briozoários) concluindo, como en 1918, pela ilade miocênica inferior da fauna. Em 1928, A. I. Oliveira, em relatório não publicado (Em Oliveira e Tueonardos 1943, p. 655). registron a formação nos rios Irindena e Maramuipi. Em 1951 o autor estudou a região juntamente com o geólogo Salustiano de Oliveira e Silva, tendo sido, então, verificado que a formação Pirabas ocupava área bem maior que a conhecida anteriormente (Oliveira e Petri 1952). Os fósseis ora descritos, foram obtidos nesta viagem. Tma pequena nota sôbre os foraminíferos desta formação foi publicada, pelo autor, em 1952.

\section{III - GEOLOGIA}

A bacia de Pirabas localiza-se no Estado do Pará, nas proximidades da costa, a nordeste da cidade de Belem (v. mapa p. 5). Ela é caracterizada por afloramentos de calcários miocênicos marinhos que aparecem nos vales, sendo encobertos, nos divisores, por sedimentos mais novos, continentais. Os sedimentos miocênicos constituem a formação Pirabas, os sedimentos continentais são considerados, duvidósamente, como plio('ênicos e conhecidos pelo têrmo rag'o de formação Barreiras(*). A bacia de Pirabas ocupa uma área de cêrca de $80 \mathrm{~km}$ ao longo do litoral, na lireção E-O, por cêrea de $90 \mathrm{~km}$ do litoral para o interior, na direção N-S. Ao longo do litoral ela se estende do rio Marapanim, no extremo oeste, ao rio Quatipuru no extremo leste. Para o interior ela ultrapassa a estrada

(*) O têrmo Barreiras é aplicado, na Geologia brasileira, a toda sequência de sedimentos continentais pouco consolidados que aparecem ao longo da costa, desde o Estado do Esp. Santo até o Estado do Pará, entrando pelo vale do rio Amazonas onde margeia êste rio e seus principais afluentes. É provável que diversas formações estejam incluidas sob esta designação. 
de ferro de Bragança atingindo, provàvelmente, o divisor entre o rio Guamá e os rios que correm para o oceano A formação Pirabas desaparece, a oeste, sob argilas e arenitos da formação Barreiras. Não se pode precisar, portanto, o seu limite ocidental. A presença de sedimentos miocêncos coarinhos na bacia de Marajó (Petri 1954), permite supôr que o Mioceno continui sob a formação Barreiras, até Marajó. Para leste, a bacia confina-se por rochas cristalinas (granito e pegmatito) que afloram nos cursos médio e superior do rio Quatipuru. Rochas cristalinas são conhecidas «m toda a região de Bragança até o rio Gurupi, na fronteira entre os Estados do Pará e Maranhão. Para o norte, é possível que a formação continui sob o mar, na plataforma continental. Ao sul do divisor Guamá-rios que correm para o oceano, não existem sedimentos da formação Pirabas. Êles poderiam ter sido erodidos (os sedimentos mergulham para o norte) ou então, o que é mais provável, nunca foram depositalos. A região do divisor Guamá - rios que correm para o oceano seria a antiga borda do mar de Pirabas. Esta última hipótese é favorecila por argumentos paleontológicos como se rerá mais adiante.

Não são conhecidos afloramentos da formação Pirabas, na região do divisor, ao sul da ferrovia. A presença de rochas calcárias é, contudo, evidenciarla pelos estudos de Sioli (1951). Sioli determinou o pH de diversos igarapés atravessados pela rodovia Belem-Capanema. Essas determina“ões foram feitas na época mais sêca do ano, quando maior era a influência do lenẹol d'água subterrâneo nêsses igarapés. A partir de Belem, o pII é ácido até o igrarapé Constantino. Dêsse igarapé em diante, o pH tende para neutro. Plausível é admitimos que a mudança do $\mathrm{pH}$ seja devido à presença de calıários atravessados pelo lençol subterrâneo, calcários êstes que pertenceriam à formacãa Pirabas. Como a rodovia passa bem ao sul da ferrovia, a área de exposição da formação ampliar-se-ia para o sul. O pH ácido dos igarapés proximos à Belem, torna improvável que o calcário por nós citado em 1952 na foz do Igarapé Caraparu no rio (xuamá, cêrca de $35 \mathrm{~km}$ a leste de Belem (Petri. 1952, p. 23-26), seja contínuo. na zona de influêneia do lençol subterrâneo. com os calcários da formação Pirabas. Talvez o calcário cle Caraparu, provàvelmente pertencente à formação Pirabas, tenha sido elevado por falhas ligadlas aos movimentos tectônicos da bacia de Marajó.

$\Lambda$ formação Pirabas aflora na ferrovia, em Tanari (afloramento 15), a $38 \mathrm{~m}$ acima do nível do mar; êste afloramento clista cêrea de $46 \mathrm{~km}$ do mais próximo afloramento litorâneo (afloramento 7 ); admitindo que não existam fenômenos tectônicos tais como falhas que modifiquem a posição dos estratos, deduzimos um mergulho de $0,82 \mathrm{~m}: \mathrm{km}$ para o Norte. Essas camadas estariam, portanto, pràticamente horizontais.

Contactos inferiores da formação Pirabas são desconhecidos, não se sabendo, por consegninte, a natureza das rochas que aparecem sob esta formacão. No litoral ela aflora na zona las marés e no interior aparecem 
sempre manchas isoladas rodeadas por solo. Contactos superiores com sedimentos da formação Barreiras não são raros. Na região de Tauari foram verificadas rochas do embasamento cristalino (afloramento 16), a $12 \mathrm{~m}$ abaixo da formação Pirabas (afloramento 15) o que permite deduzir que, pelo menos nesta área, a formação não é muito espessa. Não se conhecem afloramentos da formação que excedam $5 \mathrm{~m}$ de espessura. Contudo, em Maracanã, em área da formação Pirabas, trabalhos sísmicos permitiram inferir uma espessura de $350 \mathrm{~m}$ de sedimentos. Esses trabalhos foram posteriormente revistos e a espessura provável foi aumentada para $1.000 \mathrm{~m}$, o que permite a suposição de que rochas, talvez equivalentes ao Eoceno e Cretaceo do nordeste, apareçam sob a formação Pirabas.

\section{IV - IDADE DA FAUNA}

Observando-se a tabela n..$^{\circ}$, nota-se, como aliás era esperada, a semelhança mais estreita da fauna de Pirabas com a fauna de Cururu. Esta fauna foi considerada pelo autor (Petri 1954, p. 36) como pertencente ao Mioceno Inferior baseado, principalmente, na espécie Orbulina suturalis Bronnimann, não obstante ela se mostrar, no seu coujunto, relações mais estreitas com o Mioceno Médio de outras regiões da $\Lambda$ mérica tropical. Foram expostas então (Idem, p. 27-28), as críticas que podem ser apontadas a respeito dessas comparações faunísticas. É interessante assinalar aqui, que, do mesmo modo como foi verificado quando comparamos a fauna do Mioceno de Cururu com as de outras regióes da América tropical, também a fauna de foraminíferos da formação Pirabas, tomada em conjunto, apresenta relações mais estreitas com as do Mioceno Médio de outras regiões da América Tropical. Sempre que aparece, em uma região, outros estágios do Mioceno, além do Médio, a fauna do Mioceno Médio apresenta maior identidade de fósseis com a fauna da formação Pirabas. É o que se nota na relação abaixo, exceptuando-se naturalmente. a fama de Cururu.

1) Cururu

2) Colômbia

3) Venezuela

4) Trinidad
$\{$ Mioceno Inferior

Mioceno Superior - Usiacuri

\{Mioceno Médio - Tubara

|Mioceno Inferior - Las Perdices

Mioceno Superior -- Ojo de Agua

$\{$ Mioceno Médio - Luciano

Mioceno Inferior - Aragualiano

Mioceno Superior - Springvale

\{Mioceno Médio - Los Atajos

Mioceno Inferior - Navarro
N." de espécies comuns com Pirabas 30 0 
5) Jamaica Mioceno-Médio J Bowden 15

¡Buff Bay 11

6) Cuba

(Mioceno Superior - El Abra 9

$\{$ Mioceno Médio 16

Mioceno Inferior - Güines 8

7) Porto Rico - Mioceno Inferior $\left\{\begin{array}{lr}\text { Quebradillas } & 10 \\ \text { Los Puertos } & 10 \\ \text { Ponce } & 9\end{array}\right.$

8) Haiti - Mioceno Médio \{Port-au-Prince 4

9) São Domingos $\quad\{$ Mioceno Médio 15

Mioceno Inferior 10

A maior semelhança com associações do Mioceno Médio não é suficiente para considerarmos, desta idade, a fauna de Pirabas, visto que a maior ou menor semelhança de duas faunas pode ser reflexo dos ambientes em que elas se originaram ou do maior ou menor grau de conhecimento das mesmas. Geralmente as faunas depositadas em ambientes de águas moderadamente profundas a profundas são mais ricas em espécies que as depositadas em ambientes de águas rasas, onde há grande riqueza de indivíduos pertencentes a poucas espécies. Quando comparamos 2 faunas com um terceira, as semelhanças tendem, por conseguinte, a ser maiores com a mais rica.

Infelizmente não aparecem, na fauna da formação Pirabas, os ótimos fósseis-índices representados pelas espécies planctônicas Orbulina suturalis. Bronnimann e Globoquadrina quadraria (Cushman e Ellisor) var. advena Bermudez, encontrados na fauna miocênica de Cururu. A ausência dêsses fósseis na formação Pirabas, talvez seja devido ao maior isolamento geográfico dessa fauna em relação à de Cururu. Apezar destas considerações, a fauna estudada deve ser considerada miocênica devido aos seguintes argumentos: 1) A grande maioria das espécies descritas tem a distribuição geológica restrita ao intervalo Mioceno-Recente. 2) A espécie Oolina nuttalli (Galloway e Heminway), espécie muito característica, é restrita ao Oligoceno e Mioceno da província caraíbica. A espécie Conorbella americana Petri, sp. nov., é semelhante e possivelmente idêntica à forma descrita por Bermudez (1949, p. 240) como Disccrbis cf patelliformis (Brady), do Mioceno de S. Domingos. D. patelliformis (Brady) é encontrada sòmente no Oceano Pacífico. 3) Nossa fauna é muito semelhante a de Cururu onde aparecem foraminíferos bentônicos e planctônicos característicos do Mioceno. 4) Maury (1924, p. 43-45) considerou a fauna de Pirabas como pertencente ao Mioceno Inferior, baseada no gếnero Orthaulax, gastrópodo restrito a esta época. 


\section{V - ECOLOGIA}

ECologia das EspécIEs Nĩo EndÊMICAS - As maiores semelhanças com faunas do Mioceno Médio poderiam ser explicadas como reflexo de similaridades ecológicas. O Mioceno Médio foi uma época que se caracter izou, na região das Caraibas, pela tendência a produzir depósitos de águas moderadamente profundas, enquanto no Mioceno Inferior e Superior predominam ambientes de águas rasas. Contudo, grande cautela deve ser tomada antes de serem deduzidas similaridades ecológicas computando pura e simplesmente o número de espécies em comum.

Pode-se notar nas exposições abaixo, que o ambiente ecológico é quase que exclusivamente referido em função da profundidade. A razão dêsse procedimento é que são mais comumente encontradas, na literatura, referências sôbre a distribuição batimétrica de foraminíferos enquanto que os dados sôbre outros fatores ecológicos são escassos. Possìvelmente o que controla a distribuição dos foraminíferos não é pròpriamente a profundidade mas sim a temperatura da água, a qual diminui com a profundidade. Não obstante o fator temperatura pode ser desprezado em nossas deduções porque só foram comparadas faunas provenientes da América Tropical.

Os têrmos águas bem rasas, rasas, moderadamente profundas e profundas são citados pelos autores que tratam da ecologia dos foraminíferos, as vêzes não sendo possível especificar melhor as suas idéias. De acôrdo com o uso corrente entre os micropaleontólogos, águas bem rasas, corresponderiam, aproximadamente, a profundidade de $0 \mathrm{~m}-30 \mathrm{~m}$, águas rasas de $30 \mathrm{~m}-100 \mathrm{~m}$, moderadamente profundas de $100-200 \mathrm{~m}$ e profundas de $200 \mathrm{~m}-600 \mathrm{~m}$. Trataremos abaixo, sob o ponto de vista ecológico, das espécies não endêmicas da formação Pirabas.

As espécies de foraminíferos grandes como Amphistegina lessonii d'Orbigny e Archaias angulata (Fichtel e Moll) tem a distribuição batimétrica limitada a cêrea de $55 \mathrm{~m}$ de profundidade devido às algas comensais assim limitadlas graças a penetração de luz solar (Cushman 1948, p. 301). O gênero Strcblus é característico de águas bem rasas (Bermudez 1952, p. 71). A espécie S. catesbyanus (d'Orbigny) var. tepida (Cushman) é característica da província caraíbica, aparecendo em águas de salinidade um tanto abaixo da normal (Cushman 1931, p. 61; Phleger e Parker 1951, p. 23; Bermudez 1952, p. 74).

As espécies relacionadas abaixo, são sempre citadas, na provincia caraíbica, em águas bem rasas, sendo que Cushman e Parker (1931, p. $5,10-11,16-21,24,26-27$ ) as citam na baía de Guanabara até $5,5 \mathrm{~m}$ de profundidade: Bolivina plicatella Cushman, B. tortuosa Brady, Elphiciium poeyanum (d'Orbigny), E. sagrai (d'Orbigny), Eponides repandus (Fichtel e Moll), Pyrgo subsphaerica (d’Orbigny), Quinqueloculina lamarckiana (d'Orbigny) e Siphonina pulchra (Cushman.). Esta última 
espécie foi considerada por Phleger e Parker (1951, p. 24), que estudaram minuciosamente a distribuição batimétrica dos foraminíferos no golfo do M'éxico, como restrita ao intervalo $1 \mathrm{~m}-22 \mathrm{~m}$.

Spirillina vivipara Ehrenberg aparece na região das Caraibas, entre $2 \mathrm{~m}$ e $20 \mathrm{~m}$ de profundidade (Cushman 1931, p. 4). Phleger e Par ker (1951, p. 25) a citam no golfo do México, em região de calcário.

As demais espécies ou aparecem indiferentemente em águas rasas e profundas ou então, como a espécie Dentalina consobrina d'Orbigny, earacterística de águas profundas, são muitíssimo raras e só duvidosamente identificadas em nossa fauna.

Verificamos, pelas notas acima, que a formação Pirabas foi, presumivelmente depositada em águas bem rasas. As frequêneias de Archaias \{angulata (Fichtel e Moll), Amphistegina lessonii d'Orbigny, Elphidium poeyanum (d'Orbigny) e espécies do gênero Streblus indicam profundidades talvez inferiores a $50 \mathrm{~m}$. Esta situação parece ser contraditória ao resultado obtido de nossas comparações com faunas de formações miocênicas da América tropical, quanto ao número de espécies comuns à formação Pirabas. Como ver-se-á adiante, esta contradição é apenas aparente.

Os Facies da Formaçĩo Pirabas - Os foraminíferos da formação Pirabas indicam ambiente de deposição de águas bem rasas, límpidas e quentes e comunicação livre com o oceano devido à presença comum de foraminíferos planctônicos. A deposição extensiva de calcário, quase puro, e a ausência de sedimentos puramente clásticos mesmo em afloramentos próximos à borda da bacia sugerem que a região seria baixa e quase plana. A possibilidade de transporte de material terrígeno é evidenciada pela presença de fragmentos de ossos de vertebrados terrestres, como por exemplo em Japerica. Os afloramentos encontrados nas cabeceiras do rio Pirabas são constituidos, excepcionalmente, de calcário arenoso, evidenciando maior contribuição terrígena. As águas, devido à pequena profundidade, seriam muito movimentadas; é o que sugere a presença comum de conchas quebradas; algumas amostras de calcário podem mesino serem classificadas como coquinas (Maury 1924, p. 40). Em Salinópolis são comuns pequenos corpúseulos orbitoides achatados, os quais possìvelmente possam ser referidos à briozoários. Pela forma achatada êles fàcilmente assentar-se-iam no fundo se não houvesse movimentação da ágıa. Contudo muitos dêsses fósseis estão inclinados em relação ao acamamento. Como não havia orientação dos fósseis nos afloramentos examinados, exclui-se a presença de correntes durante a deposição dos sedimentos ou estas eram muito fracas para movimenta-los, pelo menos nos locais examinados. Corais são abundantes em diversos afloramentos, sugerindo águas rasas, límpidas e quentes. Êles não formam todavia, recifes; aparecem isolados e dispostos verticalmente em relação aos sedimentos, com cálice para cima sugerindo, para o caso dêsses celenterados, biocoenose. Outros argu- 
mentos que favorecem a dedução de ambientes de águas rasas para os sedimentos da formação Pirabas são a espessura das conchas, as quais eram suficientemente grossas para sofrerem a ação de organismos perf́uradores (Twenhoffel 1950, p. 187) e a densidade de fósseis nos afloramentos examinados sugerindo ambiente nerítico (Twenhoffel idem p. 129).

Sob o ponto de vista dos foraminíferos, os afloramentos da formação Pirabas podem ser divididos em três grupos: O primeiro grupo é representado pelos sedimentos que afloram ao longo do litoral atual, relativamente afastados, geogràficamente, da borda da bacia; o segundo é representado pelos afloramentos mais próximos da borda da bacia, e o terceiro é representado pelo afloramento do furo de Baunilha Grande (11).

Fazem parte do primeiro grupo os seguintes afloramentos: Rio Urinreua (Afloramentos 1 e 2), Fazenda (3), João Carlos (4), Castelo (5). Pedrinhas (6), Leôncio (7), Camaleão (8), rio Paracarema (9), Marapanim (17) e Salinópolis (19).

O ambiente de deposição dos sedimentos dêsse grupo seria o nerítico. de mar aberto e de águas rasas (Profundidades provàvelmente até $30 \mathrm{~m}$ ) quentes e límpidas. É o que sugere a presença abundante de Amphistegina lessonii d'Orbigny, Archaias angulata (Fichtel e Moll) e miliolídeos. A ocorrência comum de globigerinídeos indica comunicação franca com 0 veeano.

Denominamos, êste facies, de Castelo, que é o nome do local do afloramento clássico da formação Pirabas, de onde provêm os fósseis descritos por White (1887) e a maioria dos descritos por Maury (1924).

$\mathrm{Na}$ fig. 2 estão representadas as porcentagens das famílias de foraminíferos, em relação ao número de espécies, que aparecem nêsse facies. Convém assinalar aqui que a família Lagenidae é tomada no sentido de Parr (1947) compreendendo também, nesta família, o gênero Fissuriua. considerado por Cushman como pertencente à família Buliminidae, enquanto o gênero Norlosuria é aqui tomado, de acôrdo com Parr (Idem). como tipo da família Nodosariidae.

Fazem parte do segundo grupo os seguintes afloramentos: Japerica (Afloramento 10), Tauari (15) e Canecos (21, 22 e 23). Podemos juntar a êsse grupo a ocorrência da Estação Agronômica, entre as estações da ferrovia Belém-Bragança, de Timboteua e Peixe Boi, cuja fauna foi estudada por Maury (1924, p. 384 431). Infelizmente o calcário, nesta localidade, não aflora tendo sido retirado sòmente de escavações.

$O$ ambiente de deposição dos sedimentos dêsse grupo seria marinho mas de águas bem mais rasas que o ambiente do facies Castelo, profundiclade talvez em torno de $10 \mathrm{~m}$ e salinidade um tanto abaixo da normal. São abundantes aqui espécies do gênero Elphidium, principalmente $E$. poeya- 
num (d’Orbigny). Os miliolídeos, ao contrário do que acontece no facies Castelo, são raros; os amphisteginídeos também são menos numerosos. A espécie Streblus cutesbyamus (d'Orbigny) var. tepida (Cushman) é ca-

Fig. 2

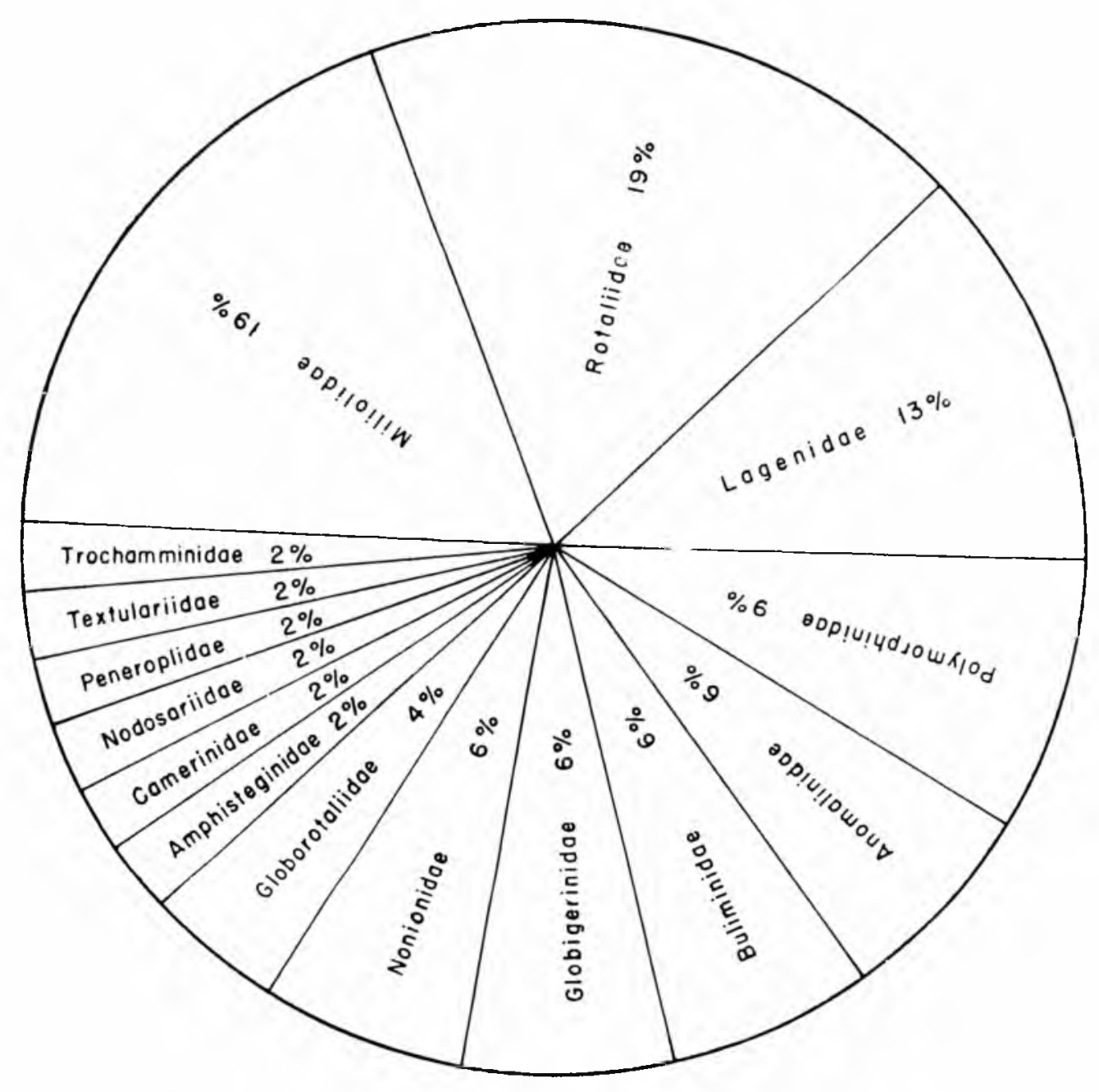

racterística dêsse grupo. Esta espécie é característica de águas bem rasas e salinidade um tanto abaixo da normal. A presença de uma fauna anã de moluscos, mostrando que as condięões não eram muito favoráveis para a vida dêsses animais, vem corroborar as nossas deduções ecológicas. $\quad \Lambda$ abundância de indivíduos pertencentes a poucas espécies é também característica de águas bem rasas. Não obstante o número de espécies é grande, sendo porém mal representadas quanto ao número de indivíduos.

Denominamos, êste facies, de Canecos, da localidade onde áparecem os seus melhores afloramentos. Na figura 3 estão representadas as porcentagens das famílias de foraminíferos, em relação ao número de espécies que aparecem nêsse facies. 
Já Maury (1924. p. 387-389) estudando os moluscos, noton diferenced entre as faumas da Estação Agronômica e de Castelo (rio Pirabas na nomenclatura de Maury ), as quais representam os 2 facies acima citados. As faunas das 2 localidades possuem em comum somente 13 espécies de moluscos. É interessante notar que todas as espécies de moluscos existentrs exclusivamente na Estação Agronômica (Em número de 31) são novas (" las 13 espécies comuns ao afloramento de Castelo, somente 2 não são exclusivas da formacão Pirabas e destas 2, uma constituí variedade nova. Notamos, portanto, acentuado endemismo na fauna da formação Pirabas. nuito mais acentuado na fauna da Estação Agronômica, representativa do facies Canecos. O mesmo pode ser dito para o caso dos foraminíferos.

Litológicamente também há diferença entre os dois facies. Os calı́arios dos afloramentos pertencentes ao facies Castelo são macissos, muito duros, dificilmente desintegráveis e grosseiros ao tacto. São comuns, nêste (aalcário, conchas quebradas (geralmente sob a forma de moldes internos) e cimentadas fracamente. A dureza destas rochas e o caráter áspero ao tacto deve-se à parcial recristalização do calcário. A conservação dos fósseis não a muito boa; como no caso dos moluscos, uma boa parte dos foraminíferos aparece sob a forma de moldes. A côr original parece ser acinzentarla: issa côr aparece muito bem no afloramento de Castelo, onde passa para laranja-amarelada que é a côr mais comum nos afloramentos, provàve]mente produzida por intemperismo. Os afloramentos encontrados mais para as cabeceiras do rio Pirabas e de outros rios, são constituílos de calcário um tanto arenoso (afloramentos 2, 7, 8 e 9 ).

Os calcários dos afloramentos pertencentes ao facies Canecos são de rrã-fina, geralmente bem claros, aparecendo em leitos espessos. Sioli (1951, p. 68), fez análises do calcário de Canecos, mostrando que êle é bem puro, apenas com vestígios de óxidos de magnésio, ferro e silício. Ao contrário do que acontece com os afloramentos do facies Castelo, os calcários aqui considerados são fàcilmente desintegráveis mergulhando-os simplesmente em água. Os macrofósseis são aqui bem mais raros que no faciess Castelo, contudo, os microfósseis são tão numerosos como naquele facies. melhor conservados, sendo raros os moldes. A descrição de Maury (1924. p. 384 ) do calcário da Estação Agronômica concorda com a de outros affloramentos do facies Canecos.

Os facies aqui estudados refletem ambientes que estão de acôrdo com a distribuição geográfica atual dos afloramentos. Os de ambientes marinhos normais estão localizados no litoral e afastados da borda da bacia e os de ambientes mais rasos localizam-se no interior ou no litoral, porém príximos à borda da bacia. Isto permite supor que esta não teria muito maior extensão do que a conhecida atualmente nos lados leste e sul, on le estão localizados os cálcarios do facies Canecos. 
Matury (1924, p. 386-388) comentando as diferenças faunísticas elltre a associação da Estação Agronônica e a de Castelo (rio Pirabas ell tha nomenclatura), deixon em aberto a questão se elas eram motivadas por facies ou idades diferentes. As evidências micropaleontológicas apontam mais para diferenca de facies do que de idade.

Fig. 3

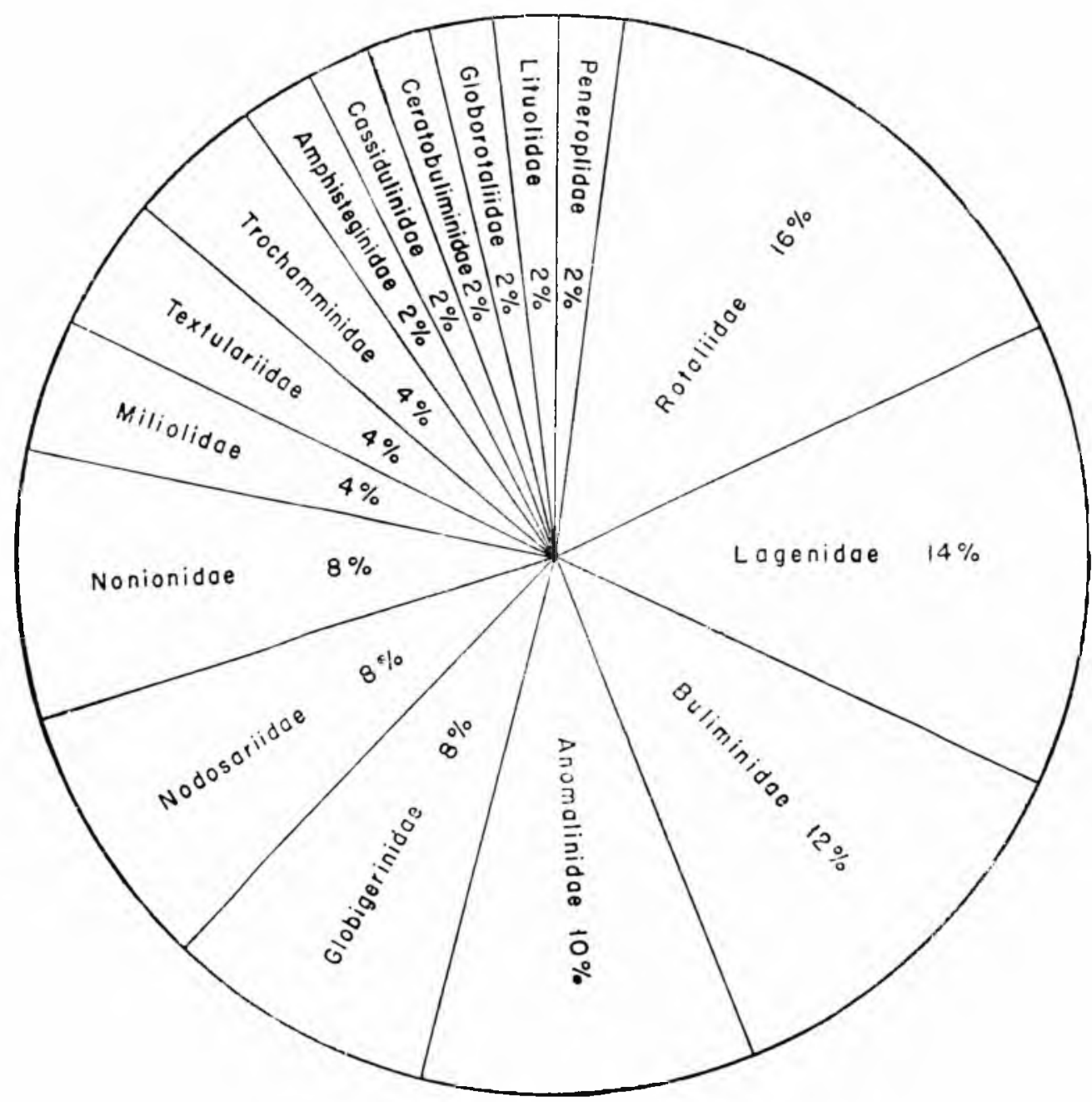

() afloramento de Bamilha Grande (11) difere dos outros, por sel. constituido de calcário finamente estratificado, com abundantes concrecóes cinza-escuras. Aparecem aqui, principalmente nas concreções, abundantes folhas de dicotiledôneas bem como restos de um peỵueno carangueijo. Pràticamente toda concreção possui, no centro, um dêsses carangueijos. Este afloramento difere dos outros, portanto, tanto litológica (o)mo paleontológicamente. Ecológicamente corresponderia a ambiente semelhante ao de mangue. Esse afloramento foi reunido aos outros do facies Canecos (na tab. 3), por causa dos seus foraminíferos, semelhantes aos que aparecem nêste facies. 


\section{VI - CORRELAÇõeS COM FAUNAS MIOCÊNICAS DA AMÉRICA TROPICAL}

As notas abaixo têm a finalidade de eselarecer melhor os dados que ('stão resumidos nas tab. 1 e 2 , relativos às especies comuns à formação Pirabas, encontradas nas formações miocênicas da América Tropical.

Colômbia - o Mioceno marinho da Colômbia é ciividido em 3 partes ( Renz 1942, p. 550-551). 1) Grupo Las Perdices 2) Grupo Tubara 3) Formação Usiacuri. As informações que se tem sôbre os microfósseis dos grupos Las Perdices e Usiacuri são muito vagas, apenas comentários de Renz (1948, p. 96) sôbre as relações com faunas da Venezuela. Não existem trabalhos que tratem especificamente dos microfósseis destas formações. Os dados são escassos para que se possa fazer comparações com a fauna de Pirabas.

Tolmachoff (1934) descreveu uma fauna do vale do rio Atrato na Colômbia, que êle considerou miocênica; esta fauna é considerada por Renz (1948, p. 96) como pertencente ao Oligoceno Superior.

A grupo Tubara é o único que possui dados faunísticos completos graças a um trabalho de Redmond (1953). Segundo êste autor, os leitos de Tubara são divididos em 2 zonas, a zona I pertencente ao Mioceno Médio e a zona II pertencente ao Mioceno Superior.

Venezuela - Embora os sedimentos do Mioceno apareçam em grande extensão e em diversas regiões da Venezuela, a única região em que os resultados do estudo da distribuição estratigráfica de seus microfósseis foram minuciosamente publicados, é o de Falcon Oriental (Renz 1948, p. 77). Aflora, nesta região, a formação Pozon; a deposição dos sedimentos desta formação inicioul-se no Oligoceno Superior e terminou no Mioceno Medio. Ela compreende diversos estágios. Só serão tratados aqui os estágios que foram depositados no Mioceno, os quais são 2, Araguatiano e Luciano. Acima da formação Pozon, aparece a formação Ojo de Agua cuja idade é miocênica superior.

O estágio araguatiano pode ser dividido, segundo $\operatorname{Renz}(1948$, p. 56 ), em duas zonas. A inferior, zona Globorotalia fohsi, de idade oligocênica superior e a superior, zona Valvulineria herricki, de idade miocênica inferior. Ecológicamente, os seus sedimentos são considerados como depositados em ambiente de mar aberto, águas profundas (provàvelmente de $200 \mathrm{~m}$ a $600 \mathrm{~m}$ ), região tropical, águas claras e salinidade normal (Renz 1948, p. 61).

O estágio Luciano é de idade miocênica inferior a média (Renz, Idem, p. 1). Êle é dividido por Renz (Idem, p. 63) em 5 unidades bioestratigráficas : zona Marginulinopsis basispinosus, zona Robulus senni, zônula Vagi- 
mulinopsis superbus - Trochammmina ef. pacifica, zônula T'extularia panamensis e zônula Elphidium poeyanum - Reussela spinulosa.

Quanto à formação Ojo de Agua, os seus sedimentos são considerador como tendo sido depositados em ambiente litorâneo ou deltaico (Liddle 1946, p. 502), razão porque somente ocasionais foraminíferos podem ser encontrados. A espécie Streblus beccarii (Limné) existente na formação l'irabas, foi citada nesta formação.

Trinidad - Embora sedimentos do Mioceno sejam muito espessos em Trinidad, não se encontram na literatura, publicacões que tratem minueiosamente da distribuição estratigráfica de seus fósseis. Segundo Renz (1948, p. 87) os depósitos do Oligoceno e do Mioceno de Trinidad são notáveis pelas rápidas variações laterais de facies as quais ocasionaram grandes confusões estratigráficas no passado. As referências estratigráficas dadas para as espécies descritas por Nuttall, Cushman e Cushman e Jarvis são frequentemente incorretas. Os dados sôbre as espécies registradas no presente trabalho como comuns à formação Pirabas (Tab.1) foram obtidos de Nuttall (1928, p. 57-115) e Renz (1942, p. 556-558; 1948, p. $125,127,137,156$ e 168). Como não temos dados completos sôbre as diferentes faunas do Mioceno de Trinidad não podemos ter idéia sôbre as porcentagens de espécies comuns à formação Pirabas.

Porto Rico - Os depósitos miocênicos de Porto Rico estão distribuidos em dluas áreas, respectivamente ao longo das costas norte e sul da Ilha. Os depósitos do norte compreendem 2 formações, ambas do Mioceno Inferior: Quebradillas e Iıos Puertos. Os depósitos do sul estão incluidos em uma única formação, Ponce, a qual, contudo, equirale a diversas formações da área norte, iniciando sua deposição no Oligoceno Superior e terminando no Mioceno Inferior.

A fauna da formação Ponce é compósita sendo, por conseguninte, muito rica notando-se formas características de águas rasas e profundas. Contudo a poreentagem de espécies comuns à formação Pirabas é pequena.

São Domngos - Os depósitos miocênicos de São Domingos são muito espalhados e compreendem diversas formações. Na tab. 1 não foram consideradas essas diversas formações e sim separadas somente as épocas do Mioceno, por efeito de simplicidade e também, devido ao fato de nem sempre estarem especificadas as distribuicões las espécies em relação às diversas formaçós da região.

() Mioceno Inferior de São Domingos é compreencliclo pelas formacões Cercado, Arroyo Blanco e Angostura. Infelizmente não está clarad, na literatura, a procedêneia da maioria dos fósseis que ocorrem no Mioceno Inferior de São Domingos, razão porque não se pode ter idéia da poreentagem de expécies comuns à formação Pirabas nas diversas formaconos 
desta épora. A formaceão Angostura contém evaporitos a o ambiente, por “onseguinte, impróprio para foraminíferos.

o Mioceno Médio de São Domingos a representado pelas formarouss (xurabo e Irroyo Seco. Infelizmente os foraminiferos da formação Gurabo provêm de grande número de afloramentos e de diversos horizontes con ambientes variando de águas rasas a moderadamente profundas e profin!las. A formação Arroyo Seco foi depositada em ambiente tilo como de águas rasas.

Bermudez (1949) cita 326 espécies de foraminíferos no Mioceno Méllio de São Domingos. Destas, foi possível verificar, pela literatura, qu* 223 ocorrem na formacão Gurabo. É possível que a fauna desta formaçàn s.ja aindla mais numerosa pois não foi possivel verificar a procedênuia ¿'e outras espécies citadas por Bermudez. Esta riqueza de espécies na formação Gurabo mostra sua origem compósita. Infelizmente faltam dados sôbre a fauna da formação Arroyo Seco.

O Mioceno Superior de São Domingos compreende as formadoues Mao. Tia e Las Salinas. Infelizmente faltam dados sôbre a fauna e ambiente de cleposição da formação Tia. Quanto às formações Mao e Las Salinais. os clados sôbre as faumas são incompletos visto existipem muitas espécies citadas por Bermudez como pertencentes ao Mioceno Superior de São Iomingos, sem contudo especificar as formações; as porcentagens de espécies comms à formacãa Pirabas cladas na tab. 2 devem ser tomadas romo uma aproximação.

Hart - Em IIaiti só á conhecido o Mioceno Médio, camadas de Portau-Prince. A fama foi estudada por Coryell e Rivero que a comsiileraram romo representativa de águas profundas.

Jamarca - As duas famas miocênicas conhecidas de Jamaica. Buff Bay a Bowlen são consideradas do Mioceno Médio. Segundo Cushman e - arvis (1930), p. 35.3) os sedimentos de Buff Bay foram depositades em ́nguas moleradamente profundas, talvez $180 \mathrm{~m}$ a $360 \mathrm{~m}$. Quanto à forma(ão Bowden. Woolring (1928, p. 32-36) baseado nos moluscos, a Palmer (1945, p. 12-15) basearla nos foraminiferos, chegam a illênti(‘as conclusões ecológicass, isto $a$. encontram-se misturados em Bowden, elementos faunísticos de diver'sa profundidades ocêanicas. Apesar da espessura da formação Bowden ser de cêrea de $75 m$ (Woodring 1925, p. 8), a fauma provem, em sua maioria, da base, comstituida de $60 \mathrm{~cm}$ a $90 \mathrm{c} \cdot \mathrm{m}$ de numa rocha conglomerática com seixos pecuunos de rochas ínneas, calcários e untros tipos de seixos mergulhados em matriz marosa. Segundo Moohring (1928. p. 35-36) ésses sedimentos representam deposicão ao longo de declive desusualmente íngreme produzindo, na base do declive. mistura de faunas dir diversas profundidades. 
CUBa - o Mioceno Inferior em Cuba é representado pela formação Giiines. Os dados sôbre a sua fauma foram fornecidos por Bermudez $(1950$, p. $293-295)$.

Os dados sôbre a fauma do Mioceno Médio de Cuba, mostrados na 'Tab. 1, foram obtidos da tabela de distribuição estratigráfica geral dos foraminíferos de Cuba, publicada por Bermudez (1950, p. 325-367). Esta fauma, todavia, é compósita e provem de 2 formaçóes equivalentes no tempo, mas depositadas em ambientes diferentes: Formações Canímar e Isa Cruz.

() Mioceno Superior de Cuba é representado pela formação El Abra. Os depósitos desta formação indicam ambientes muito costeiros e em parte não marinhos (Bermudez 1950, p. 293).

Não tentamos comparar a fauna de Pirabas com a do Mioceno da zona do canal do Panamá, deserita por Cushman em 1918, visto a necessidade de revisão da sucessão estratigráfica e distribuição de seus fósseis. As outras ocorrêneias do Mioceno na América Central são insuficientemente conhecidas para se tentar correlaçóos.

Na tab. 2 estão relacionadas as formações discutidas em ordem decres'ente de porcentagens de espécies comuns à formaçãa Pirabas. Não foram consideradas as formações cujos dados não permitem estabelecer essas porrentagens. Verifica-se, nesta tabela, que as formações ticlas como depositalas em águas bem rasas (profundidades menores que $30 \mathrm{~m}$ ) são as gue apresentam maiores porcentagens de espécies commus à formação Pirabas.

Vemos por esta tabela, que as faunas clas formações Bowden e Gurabo, consideractas por Maury (1924, p. 43-45) como se assemelhanclo muito a da formação Pirabas, se afastam desta última quando consideramos as porcentagens de espécies cle foraminíferos comuns. É possível inle o mesmo ocorra com os moluscos. Vemos por conseguinte, que a maior. semelhança da fauna de Pirabas com faunas do Mioceno Médio, apontarla lials 1). 8 e 9 é apenas aparente.

\section{VII - AFLORAMENTOS E DISTRIBUIÇĀO DOS FORAMINífEROS}

Os afloramentos referidos no presente trabalho podem ser localizados no mapa da p. $j$ pelos números e êles atribuílos. Empregamos i mesma numeração usada no trabalho de Oliveira e Petri (1952). ()s números 12, 13, 14 e 16 não foram considerados por representarem aflolamentos do embasamento cristalino do pré-(tambriano (granitos a peymatitos). Os números 18 a 20 representam afloramentos de arenitos afossilíferos, não pertencentes à formação Pirabas, razão porcue também não foram considerados. Além dos afloramentos referidos por ()liveira e Petri. for ram arui também considerados cis afloramentos de Caneros. registrados 


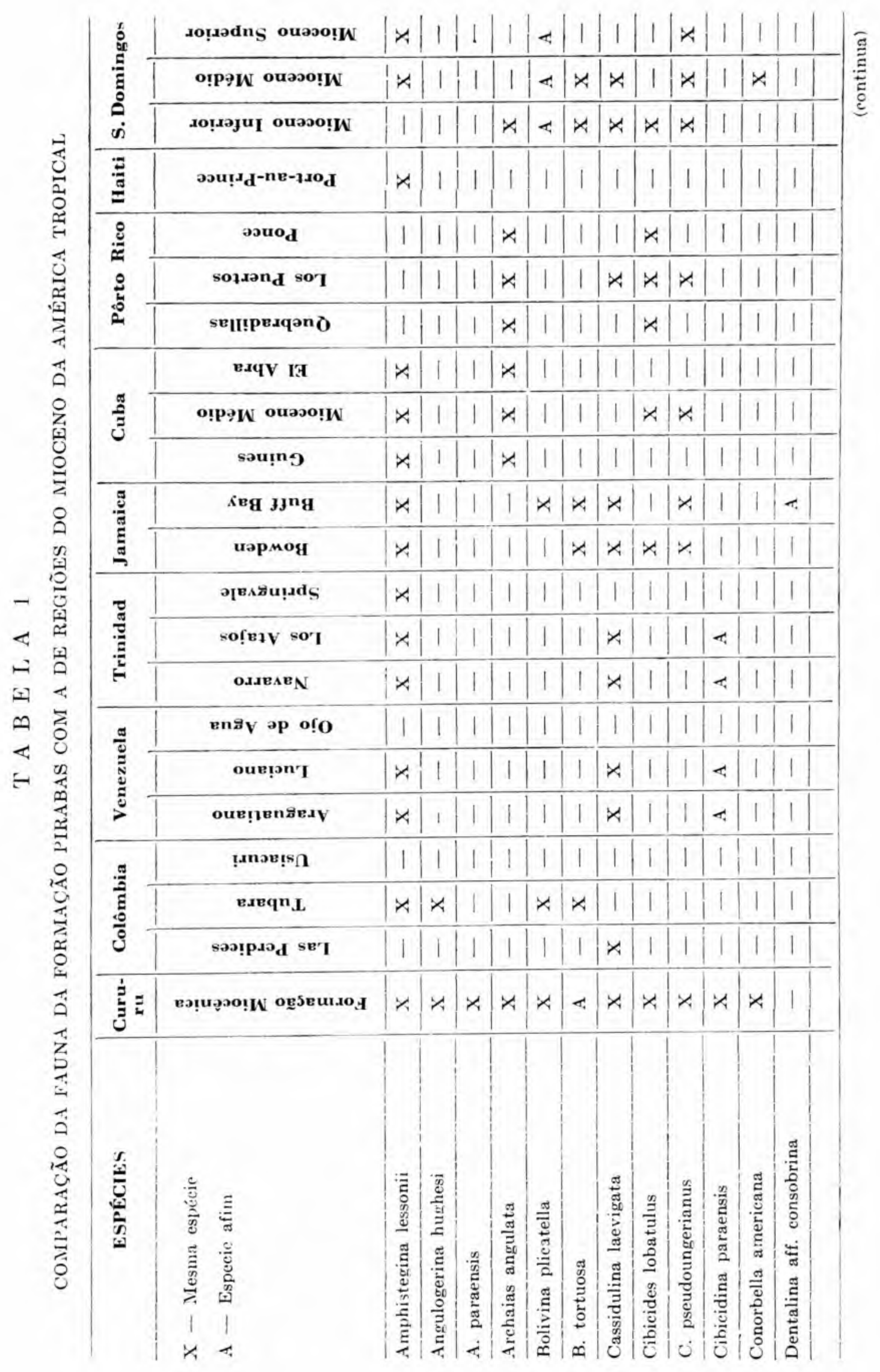




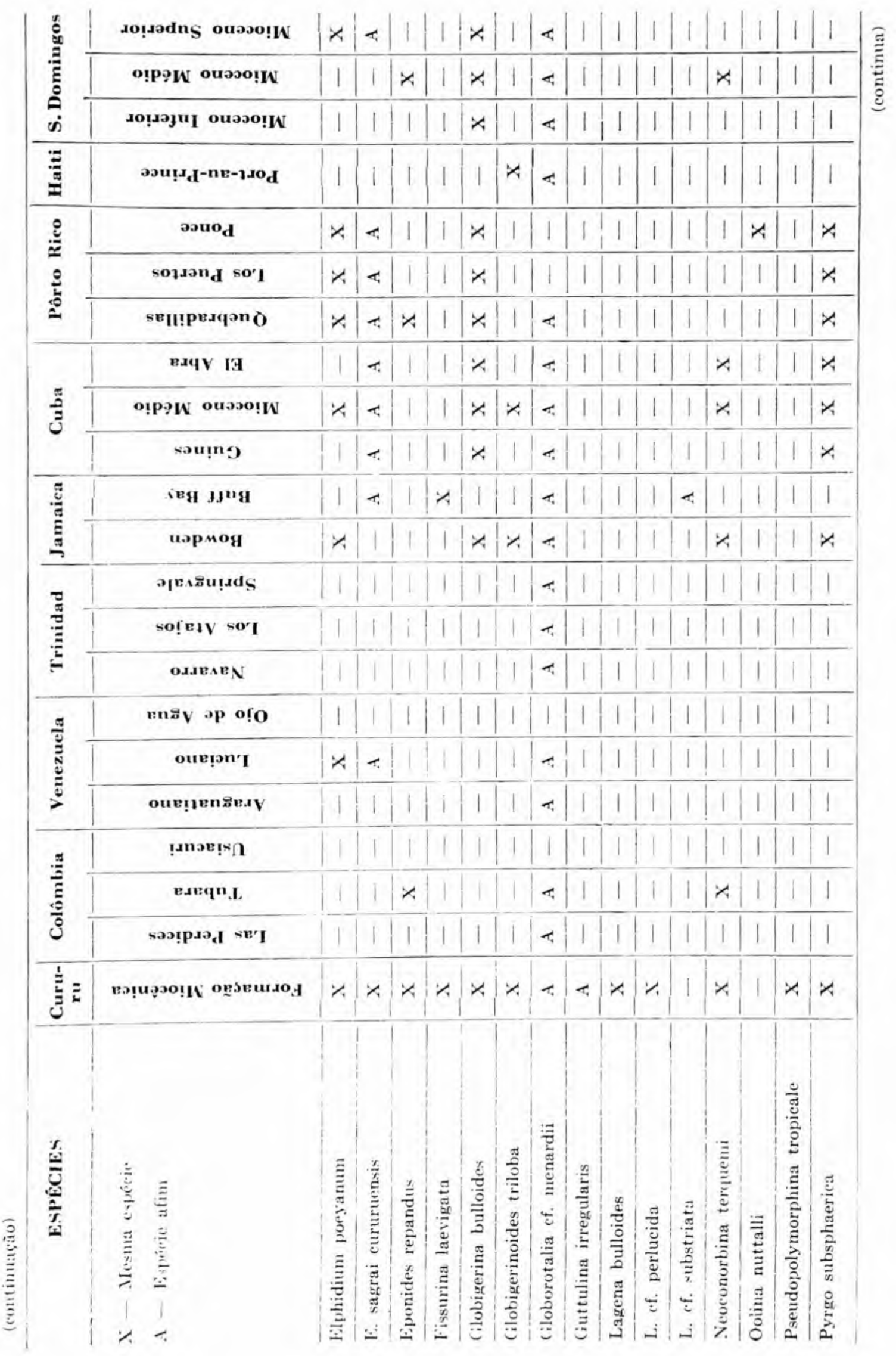




\begin{tabular}{|c|c|c|c|c|c|c|c|c|c|}
\hline \multirow{3}{*}{ 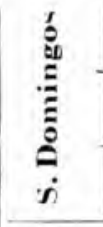 } & so!radns оuәэо!W & i & $x$ & 1 & x & 1 & 1 & $x$ & 14 \\
\hline & 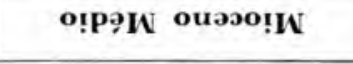 & $\%$ & $x$ & 1 & $x$ & 1 & 4 & 1 & $x$ \\
\hline & ло!мәуй оиээо!W & 1 & $x$ & 1 & 11 & $\mid 1$ & 4 & 1 & 1 \\
\hline$\stackrel{ت}{ت}$ & oxu!xd-ne-1.xod & 1 & 1 & 1 & $x$ & 1 & 1 & 1 & 1 \\
\hline \multirow{3}{*}{ 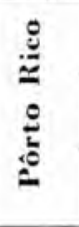 } & əouod & 1 & 1 & 1 & 11 & $x$ & 1 & 1 & ix \\
\hline & ${ }^{\text {soldand }}$ so'T $_{T}$ & 1 & 1 & 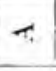 & 1 & 1 & 1 & 1 & 4 \\
\hline & sEII!pedqәn & 1 & 11 & 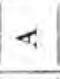 & 1 & 1 & 1 & 1 & $x$ \\
\hline \multirow{3}{*}{ تُّ } & ExqV IT & 11 & $x$ & 1 & 1 & 1 & 4 & 1 & 1 \\
\hline & о!pэW оuәзо!W & 1 & $x$ & 1 & $x$ & $\pi$ & 1 & $x$ & $\%$ \\
\hline & sau!ng & 1 & $x$ & 1 & 1 & 1 & $\tau$ & 1 & 1 \\
\hline \multirow{2}{*}{$\stackrel{\stackrel{g}{\tilde{g}}}{\tilde{g}}$} & Keg $\boldsymbol{y} \boldsymbol{y}^{\mathrm{n}} \mathrm{g}$ & 4 & 1 & 1 & $x$ & 1 & 1 & 1 & 1 \\
\hline & иәрмоя & $x$ & 1 & 1 & $|x|$ & 4 & 1 & $x$ & 1 \\
\hline \multirow{3}{*}{ 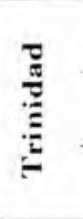 } & 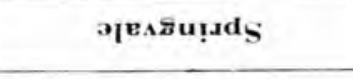 & 1 & 11 & 1 & 1 & 1 & 4 & 1 & 1 \\
\hline & $\operatorname{sof} e_{1} s^{\prime} o_{1}$ & 1 & $x$ & 1 & 1 & 1 & $\pi$ & 1 & 1 \\
\hline & OLAEAE & 1 & $x$ & 1 & 1 & 1 & 4 & 1 & 1 \\
\hline \multirow{3}{*}{ 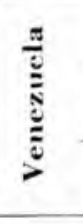 } & enE్ op ofo & 11 & 1 & 1 & 1 & 1 & 4 & 1 & 1 \\
\hline & our!an T & 1 & 11 & 1 & 1 & 1 & 4 & 1 & 1 \\
\hline & оนย!ุอกลอมู & 1 & $x$ & 1 & 1 & 1 & 1 & 1 & 1 \\
\hline \multirow{3}{*}{ لَّ } & !.unse!• & 1 & 1 & 1 & 1 & 1 & 1 & 1 & 1 \\
\hline & exeqn $n_{L}$ & $x$ & 1 & 1 & $x$ & 1 & 4 & 1 & 1 \\
\hline & sos!pมad ${ }^{\text {sE }}$ & 1 & 1 & 1 & 1 & 1 & 1 & 11 & 1 \\
\hline 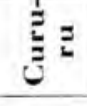 & 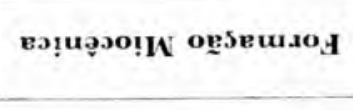 & $x$ & $x$ & $x$ & $x$ & 1 & x & 1 & $x$ \\
\hline 而 & 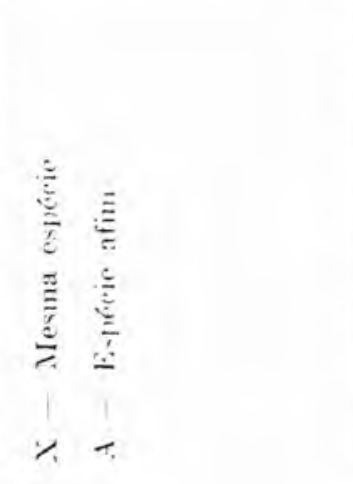 & 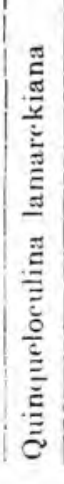 & 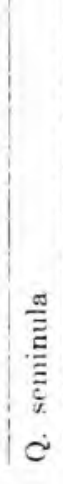 & $\begin{array}{l}\frac{1}{\bar{x}} \\
\mathrm{c}\end{array}$ & 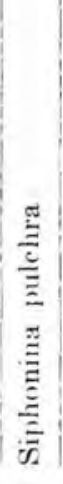 & 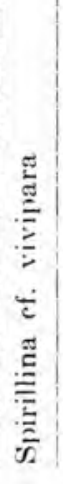 & 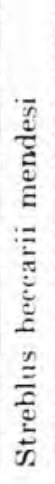 & 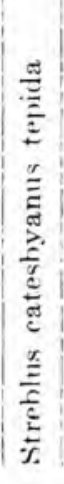 & 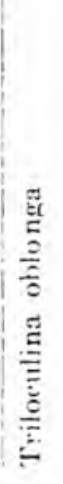 \\
\hline
\end{tabular}


pela primeira vez por Sioli (1951, p. 67-69) e o afloramento do iqarapé Caraparm. A verificação de rochas pertencentes ao Mioceno e. provàvelmente, em parte equivalentes à formação Pirabas, em uma sondagem na illa de Marajó (Petri 1954), vem aumentar a possibilidade de extensão de rochas miocênicas até o igarapé Caraparu. () Mioceno ter-se-ia elevado até a superfície, nesta área, por mor mentos tectônicos. A Leinz havia notado (em Petri; 1952, p. 25) evidências de movimentos tectônicos no calcário de Caraparu. Esta idéia é reforçada pelos estudos geofísicos que demonstraram a presença de uma área estruturalmente mais alta, ao redor de Belém, estando também compreendida nesta área, o igarapé Carapuru (Petri 1954, fig. 1). (os foraminíferos provenientes do (alcário do igarapé ('araparu são raros devido a dificuldade de clesintegração da rocha. Predomina o gênero Quinqueloculina aparecendo também alouns foraniníferos rotaliformes. impossíveis de serem classificados dericlo ao estado de conservação. Alguns ostracoilos também foram separados. O estado de conservacão dêsses fósseis não permite que se estabeleça. fork de dúvida, a identidade do calcúrio do igarapé Caraparu com a formacão Pirabas.

() calcário que aflora no rio laracarema (Afloramento 9). é muito duro e difícil de se desintegrar e além disso parcialmente recristalizado, razão porque os foraminíferos coletados são raros, nenhum característico. Contudo, outros tipos de fósseis são relativamente comuns. Nos outros afloramentos estudados a riqueza em foraminíferos é variável, mas êstes sempre aparecem em número expressivo.

O) afloramento de Japerica (10) foi um dos que forneceu maior múmoro de fósseis, talvez pela facilidacle de lesintegração da rocha. Com o Iito de mostrar a abundância de foraminíferos fósseis nesta rocha, o que servirá também para se ter idéia da frequência em outros afloramentos, desintegroul-se 50 ce de sedimento e obteve-se o seguinte resultado:

\begin{tabular}{|c|c|}
\hline Número total de foraminíferos & 1074 \\
\hline Número de foraminíferos bentônicos & 947 \\
\hline Número de foraminíferos planctônicos & 127 \\
\hline Indivíduos pertencentes à espécie Textularia japericensis Petri, sp. nov. & 306 \\
\hline Individuos pertencentes a espécie Cibicidts pirabensis Petri. «p. nov. & 341 \\
\hline Outros foraminíferos bentônicos & 300 \\
\hline 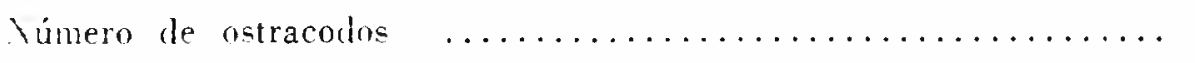 & 500 \\
\hline Poreentagene de Cicibides piraberusis Petri, spe nor.. $\quad$. $\quad \ldots$ & $31,7.5 \%$ \\
\hline Porcentagem de Texiularia jap ricensis Petri. sp. nov. .. & $23.49 \%$ \\
\hline Porcentsgem de foraminíferos planctônicos $\ldots \ldots \ldots \ldots \ldots \ldots$ & $27.94 \%$ \\
\hline
\end{tabular}




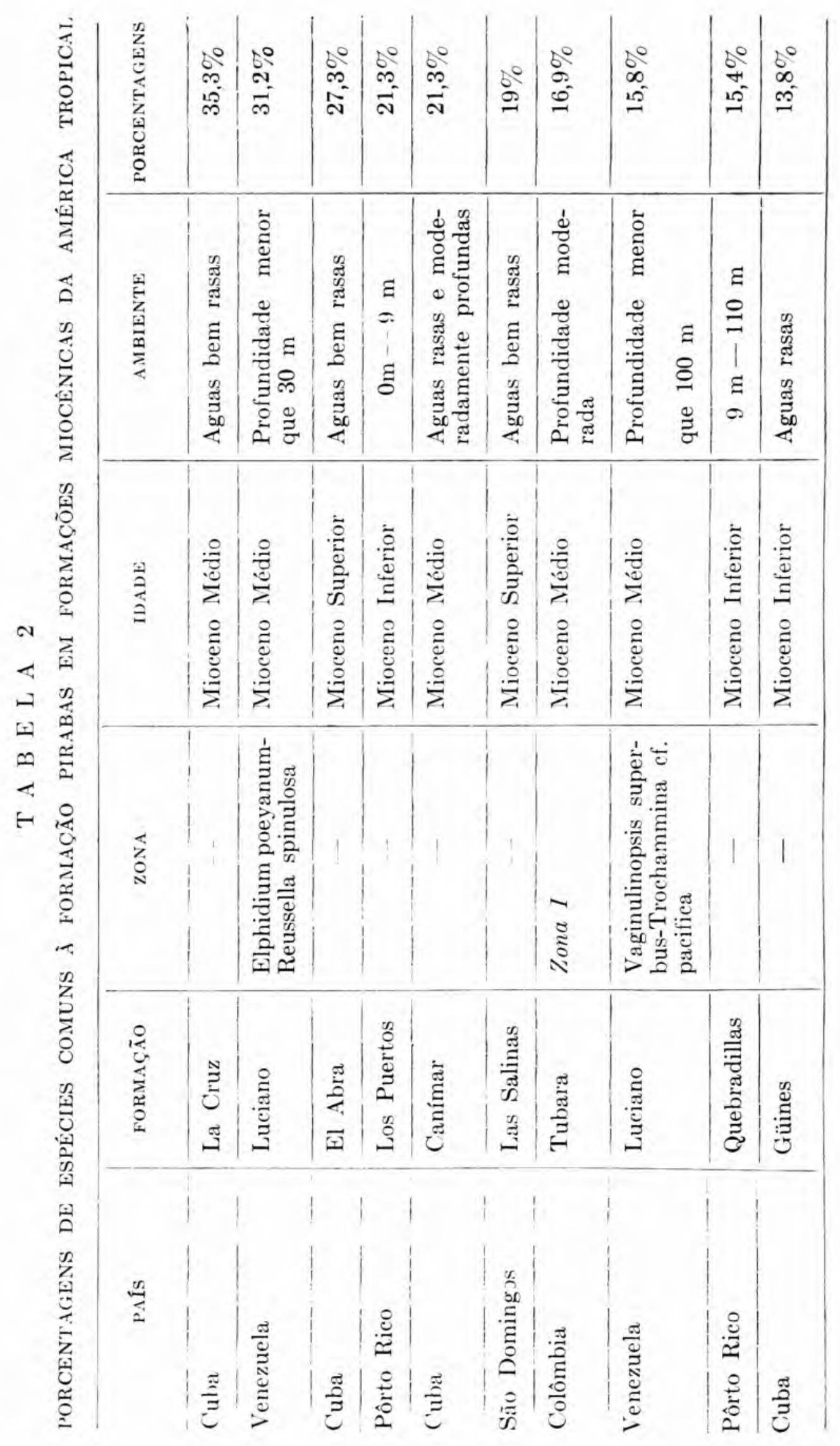




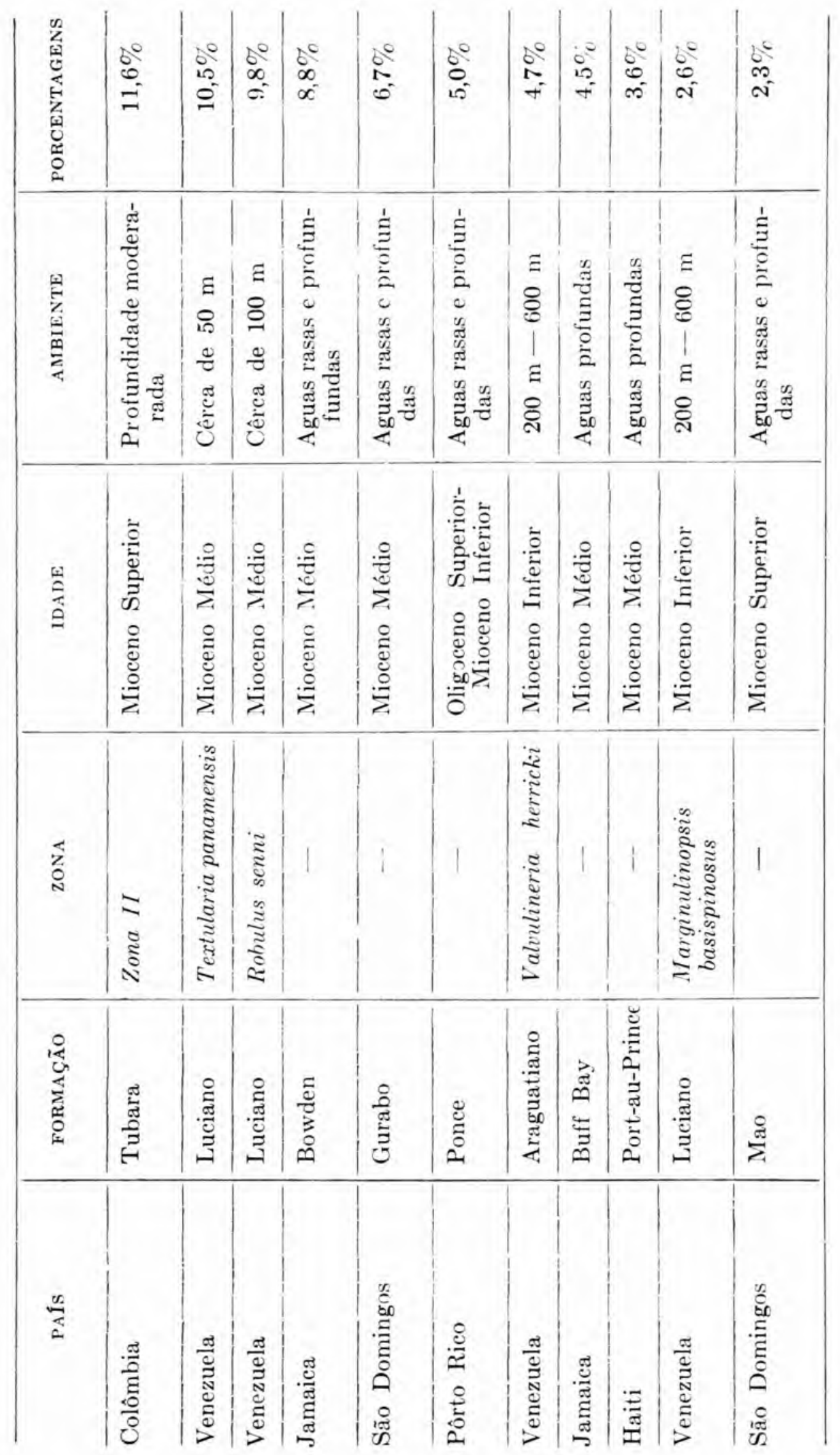


()s afloramentos de Canecos localizan-se a cêroa de 500 metros a sudoeste de (apanemea de ambos os lados da rodovia Bonito-Capanema. Em imm peouneno corte desta rodovia aparece o afloramento representado pelo número 21 . ()s afloramentos representados pelos numeros 22 e 23 aparecem em cluas escavacooses artificiais para exploracõo do calcário, respectiramente a direita e ì esculuerla da rodovia, para quem rem de Bonito. $\Lambda$ espessura do calcário nas citaclas escavações não ultrapassa $4 \mathrm{~m}$. Contudo não foi atingila a base da formacãon. () calcário é homogêneo e em bancos le espessuras variáveis, em torno de $1 \mathrm{~m}$, separarlos por leitos de alguns rentímetros de calcário menos resistente e em camadas finas. Raros seixos de quartzo aparecem na parte inferior. Consegumos encontrar nas camadas próximas ao topo das escavacões, lamelibrânquios do gênero Pecten, aloums bem conservados.

Com o fito de se ter idéia da distribuicão estratigráfica dos foraminíferos na formacão Pirabas, foram coletadas quatro amostras tanto do afloramento 20 como (10 23. A primeira foi tomada na base da secção, a segunda um metro acina, a terceira dois metros e a quarta três metros. Chamamos essas amostras rexpectivamente, 22a, 22b, 22c, 22d, 23a, 23b, 23e e 230. Verifica-se que há variaroós na fama coletada nêsses diversós nívei.s. Noumas amostras como as tomadas a 1 me a 4 m acima cla base lo afloramonto 2.2. não forneceram foraminíferos. Não é fácil explical a lazão disso, visto que as amostras obticlas, da base da sececão (22a) a a $2 \mathrm{~m}$ acima (220) e rlo (corte la rodovia Bonito-Capanema, a qual fica alguns metros acima do tôpo das escavacoões artifíciais (Afloramento 21), são relativamente ricas. A fauna proveniente do corte da rodoria (afloramento 21), foi a que se mostrou mais rica em fósseis. Esta riqueza talvez seja apenas aparente, visto que éste afloramento estara semidecomposto, de maneira que a sud desintegração foi mais completa. Quanto ao afloramento 23, não foram encontrados fósseis somente na base da secção (23a), aparecendo fósseis nas amostras tiraclas a $1 \mathrm{~m}, 2 \mathrm{~m}$ a $3 \mathrm{~m}$ acima da base.

As pequenas rariaçoes faumísticas observarlas nos diversos níveis dos Ifloramentos de Canecos são, ao que parece, devidas aos azares da coleta on conservação e nãa tem, possivelmente, significado estratigráfico.

Ibaixo damos a relação dos afloramentos e seus respectivos números: (ver mapa, p. 5).
N.
Local
Descrição
Espessura (em
1 - Rio Urindeua
2 - Rio Urindeua
3 - Fazenda 


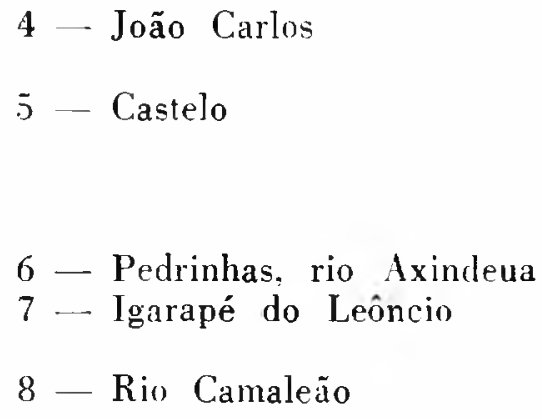

23 - Canecos (Escavação a es. querda da rodovia)
- Calcário amarelo, duro, em blo- — 1,50 cos destroçados pelas ondas.

- Calcário em 2 leitos espêssos, - 2,50 duro, varianclo de amarelo a cinzento esverdeado, em parte are. noso.

- Blocos de calcário amarelo, duro. - 1.00

- Calcário amarelo e cinzento, are- - 0,30 noso, duro.

- Leitos destrogados de calcário - Fundo do iio

amarelo em parte cinzento esverdeado, duro, com grãos de quart. zo esparsos em sua massa.

- Calcário amarelo, muito duro, - 1.00 com grãos de quartzo esparsos em sua massa.

- Calcário muito fino, mole, ama- - 2,00 relo bern claro. em leitos espêssos.

- Leito delgados de calcário cin- _ 1,00 zento duro. Concreções calcárias com fósseis no interior. Folhas bem conservadlas e crustácens.

- Calcário muito fino, mole, ama- — 2.00 relo claro em fragmentos destroçados pelo intemperismo.

- Cálcario azul, em parte amareln, _ 0.55 duro.

- Calcário amarelo, duro, em blo- - 1.00 cos destroçados pelas ondas.

- Calcário muito fino, mole, ama- - 1,00 relo bem claro, em fragmentos destroçados pelo intemperismo.

- Calcário muito fino, mole, amarelo claro, constituido de bancos de cêrca de $1 \mathrm{~m}$ de espessura separados por alguns centímetros de cálcario menos resistente, em leitos finos.

- Calcário igual a $22 \quad-4.00$

\section{VIII - DESCRIÇÃO DAS ESPÉCIES}

Tôda a fauna estudada está depositada na Coleção do Departamento de Geologia e Paleontologia da Faculdade de Filosofia, Ciências e Letras da Tinversidacle de são Paulo, sob os números VII-323 a VII-339e VII-3+1 a VII-417.

Para não nos estendermos na lista bibliográfica que damos logo abaiso das espécies descritas, citamos, sempre que possível, publicações an- 


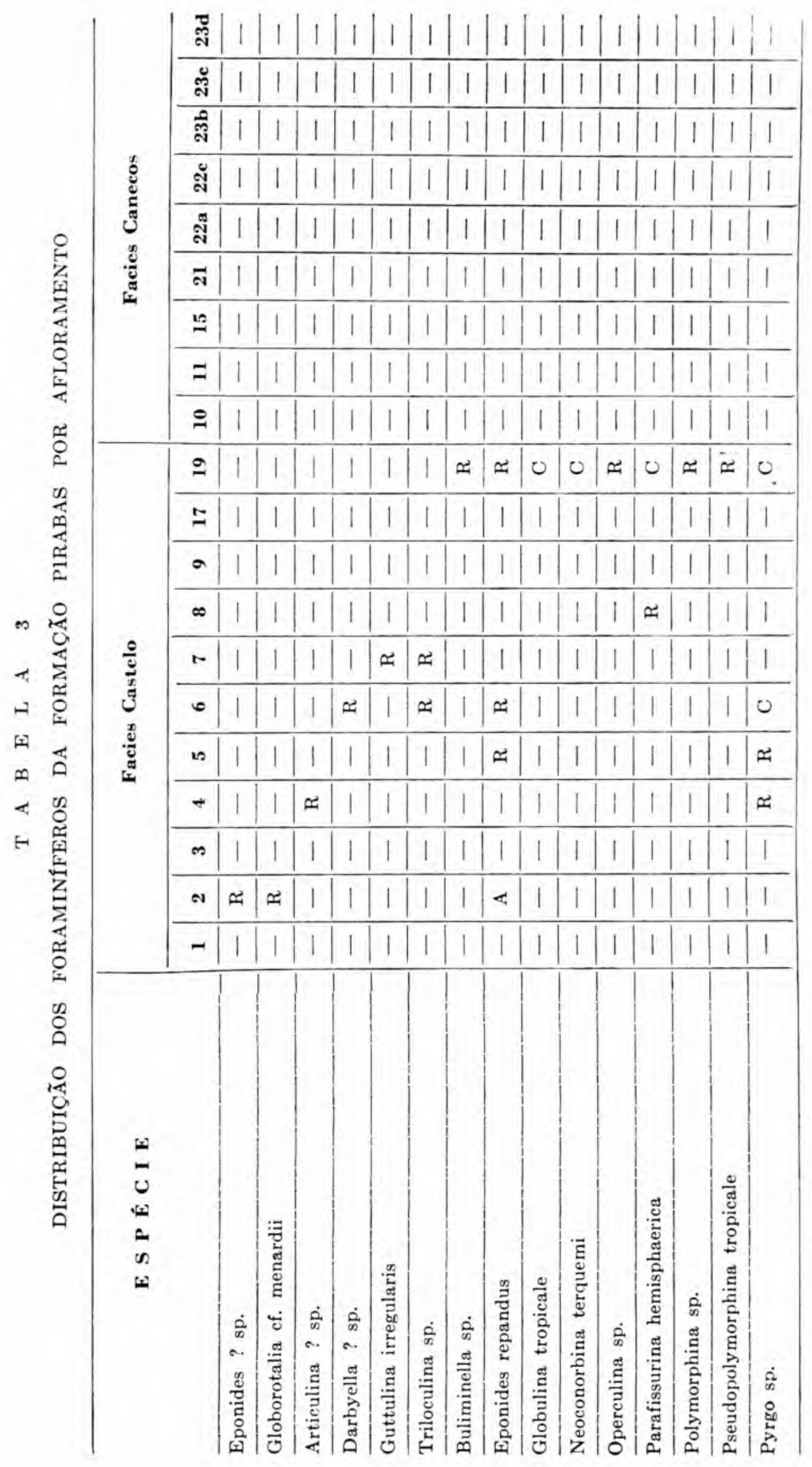




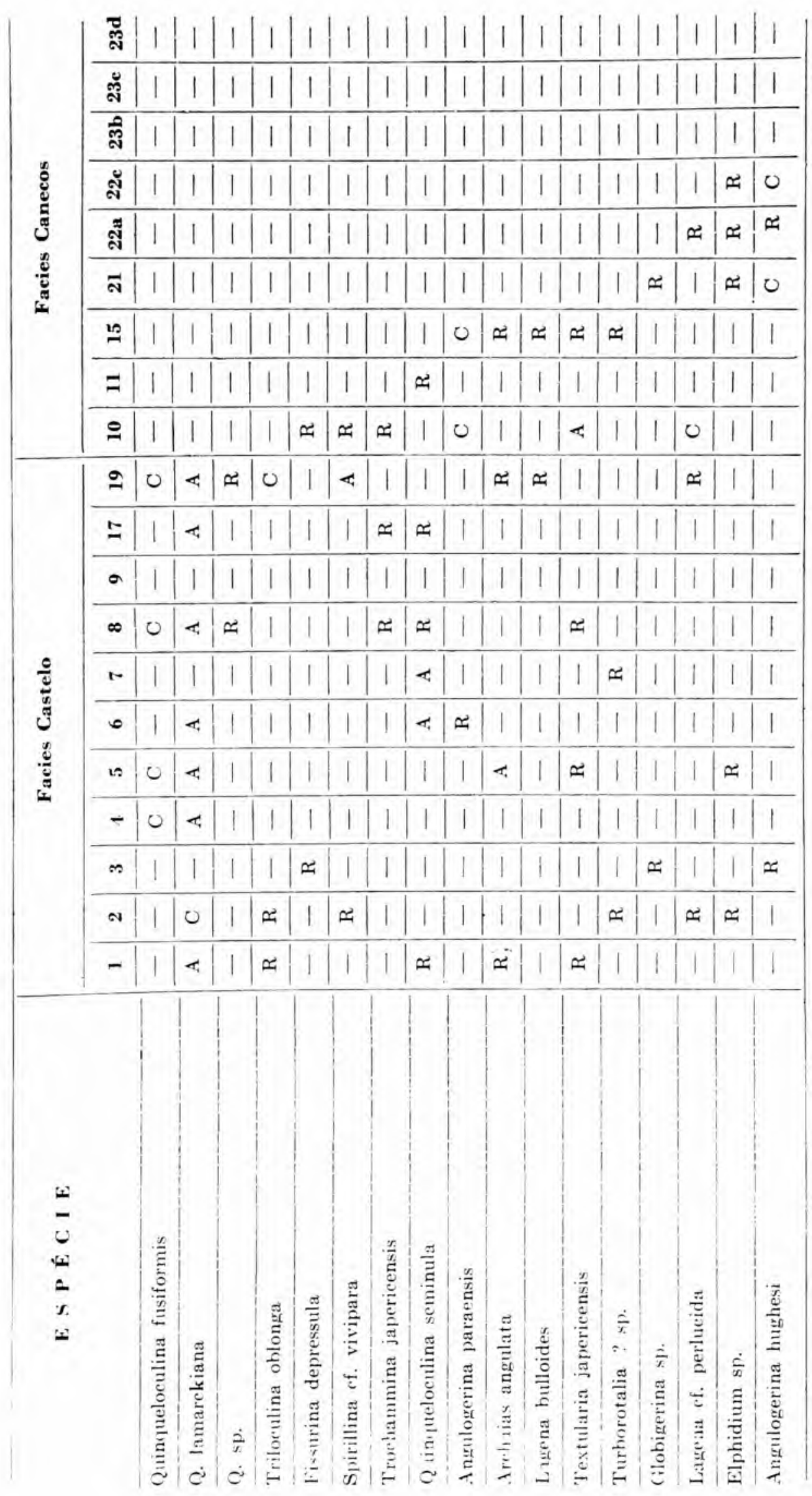




\begin{tabular}{|c|c|c|c|c|c|c|c|c|c|c|c|c|c|c|c|c|c|c|}
\hline \multirow{9}{*}{ 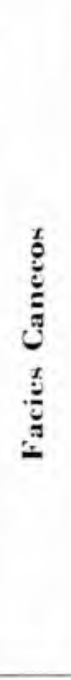 } & & 1 & 1 & 1 & 1 & 1 & 1 & 2 & 4 & 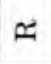 & 4 & $\approx$ & $\varangle$ & 0 & 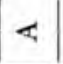 & 0 & 0 & $\pi$ \\
\hline & สั & 1 & 1 & 1 & 1 & $\simeq$ & $\approx$ & 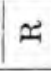 & 2 & 요 & 4 & 1 & 4 & 1 & $\varangle$ & 요 & $\approx$ & 1 \\
\hline & जิ & 1 & $\simeq$ & $\approx$ & ४ & د & 0 & 4 & 0 & 4 & $\pi$ & 0 & 4 & 1 & 4 & 1 & 4 & 0 \\
\hline & มั & 0 & 1 & 1 & $\varangle$ & $\approx$ & 4 & 1 & يح & يح & 1 & 1 & 4 & $\approx$ & 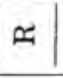 & 1 & $\approx$ & 4 \\
\hline & สี็ & 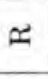 & 1 & 1 & $\varangle$ & $\simeq$ & 4 & 1 & م & $\approx$ & $\approx$ & 1 & $\varangle$ & $\approx$ & ن & 0 & $\approx$ & $\varangle$ \\
\hline & $\overrightarrow{\mathrm{N}}$ & 0 & 1 & 1 & 4 & $\simeq$ & 2 & 1 & 1 & $\simeq$ & 1 & 1 & 4 & 1 & 0 & $\approx$ & $\approx$ & 0 \\
\hline & $\stackrel{12}{2}$ & $\approx$ & 1 & 1 & 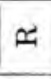 & 0 & 4 & s & 0 & $\varangle$ & $\approx 1$ & ع & 4 & $\approx$ & 4 & $\approx$ & $\approx$ & 1 \\
\hline & $=$ & 1 & 1 & 1 & 1 & 1 & 1 & 1 & 1 & 1 & 11 & 1 & $\varangle$ & 1 & $\approx$ & 1 & 11 & 1 \\
\hline & $\varrho$ & تح & $\simeq$ & $\approx$ & 1 & $\approx$ & ن & 11 & $\approx$ & ד. & $\approx$ & $\approx$ & 1 & 1 & +1 & 0 & $\varangle$ & 1 \\
\hline \multirow{11}{*}{ 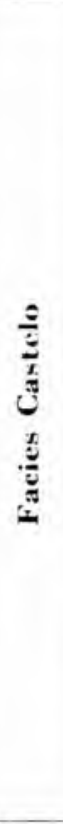 } & $\underline{2}$ & $\approx$ & 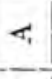 & 1 & T. & 1 & $\simeq$ & 4 & ح & $\approx$ & $\approx$ & 4 & 0 & 4 & $\approx$ & 11 & 1 & 4 \\
\hline & \pm & 1 & د & 1 & $\approx$ & 1 & 1 & $\approx$ & 1 & 1 & 1 & 1 & 1 & 1 & 1 & 1 & 1 & 1 \\
\hline & $\theta$ & 1 & 1 & $\approx$ & 1 & 1 & 1 & 1 & 1 & 1 & 1 & 1 & 1 & 1 & ت & 1 & 1 & 1 \\
\hline & $\infty$ & 1 & $\approx$ & 1 & 1 & 1 & 0 & I & 0 & 1 & 1 & 1 & 1 & 1 & $\approx$ & 1 & 11 & 1 \\
\hline & is & 1 & 1 & 1 & 1 & يح & $\approx$ & 1 & r & $\approx$ & 0 & $\approx$ & 1 & 1 & 4 & $\approx$ & $\approx$ & 1 \\
\hline & $e$ & 1 & 4 & 1 & 1 & بح & 1 & 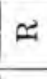 & $\approx$ & $\approx$ & $\approx$ & 1 & $\approx$ & 1 & 0 & 11 & 11 & 1 \\
\hline & 10 & $\simeq$ & $\varangle$ & 11 & 1 & 1 & 1 & 0 & 1 & $x$ & 1 & 1 & $x$ & 1 & 1 & 11 & $\approx$ & 1 \\
\hline & + & 1 & 0 & 1 & 11 & $\approx$ & 1 & 0 & 1 & 1 & 11 & 0 & 1 & 1 & 11 & 11 & 11 & 1 \\
\hline & $\infty$ & 1 & 0 & 1 & 4 & 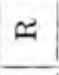 & I & ४ & 1 & 요 & 1 & 1 & r & 1 & 11 & $\approx$ & 11 & 1 \\
\hline & N & ع & 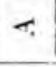 & 1 & 1 & 2 & 2 & $\varangle$ & s & 우 & 1 & 0 & 0 & 1 & 4 & $\approx$ & $\approx$ & 1 \\
\hline & - & 1 & 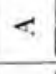 & 1 & 1 & 1 & 1 & $\approx$ & 1 & 1 & 11 & 1 & 1 & 1 & 11 & $\approx$ & 11 & 1 \\
\hline $\begin{array}{l}0 \\
\text { s } \\
-1 \\
-1\end{array}$ & & 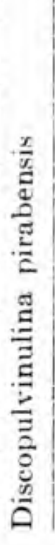 & 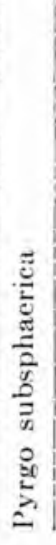 & 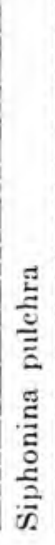 & 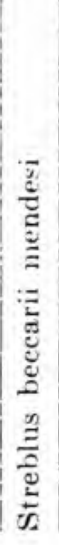 & 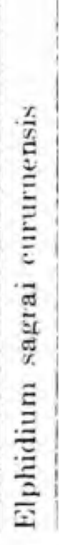 & 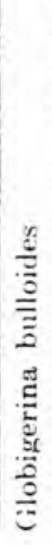 & 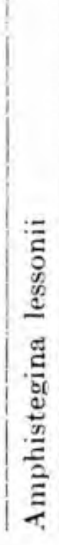 & 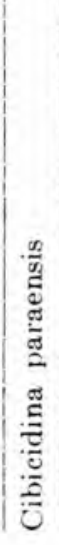 & 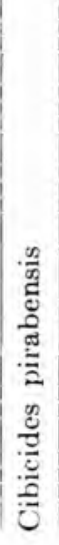 & 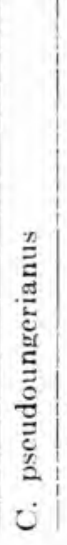 & 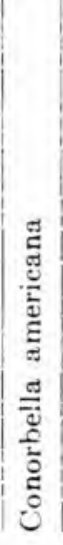 & 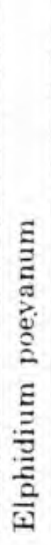 & 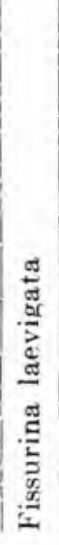 & 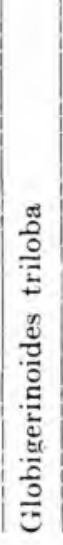 & 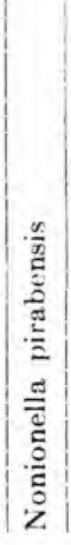 & 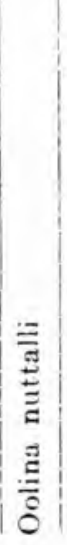 & 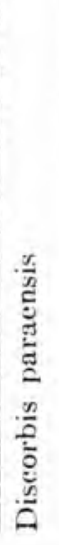 \\
\hline
\end{tabular}




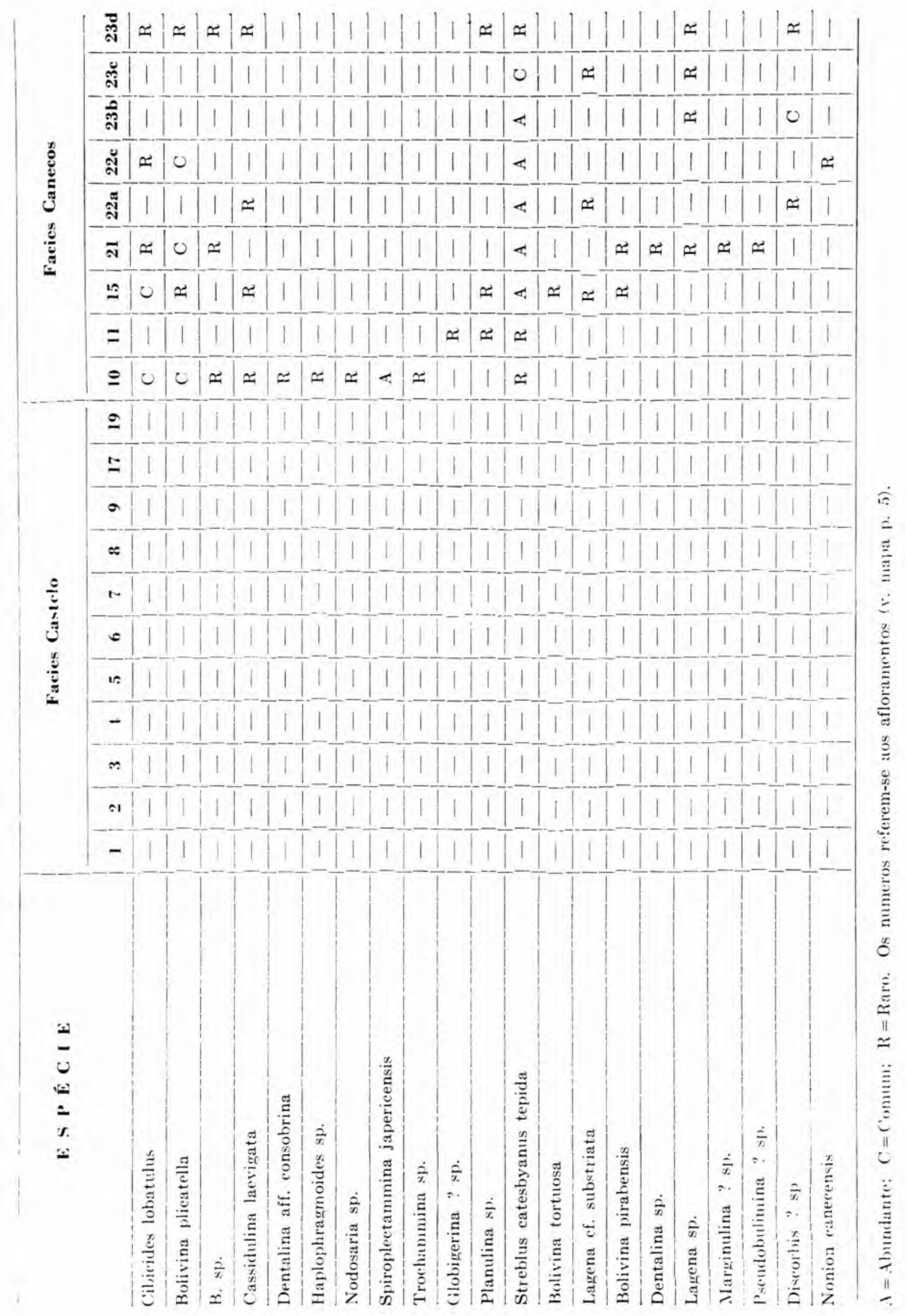


teriores que tratem mais extensamente dessas referências; colocando adiante das citações dessas publicações, o têrmo "referêneias" fornecemos as fontes para se chegar à relação completa.

Na descrição das espécies seguiu-se a ordem clada pelo tratado de C'ushman (1948).

\section{Haplophragmoides sp.}

\section{Est. 1 Fig. 1}

Material - Dois indivíduos.

Descrição - Testa pequena, deprimida, planospiral involuta; periferia não on muito ligeiramente lobulada, largamente arredondada; câmaras distintas, cêrca de 7 na última volta do corpo; suturas distintas, ligeiramente deprimidas; parede arenosa mas com muito cimento e com acabamento liso; a abertura consiste em uma fencla na base da face aperturar.

Dimensões - Espécime figurado: Diâmetros $0.26 \mathrm{~mm}$ e $0.20 \mathrm{~mm}$; essjessura : $0.10 \mathrm{~mm}$.

Observações - Esta espéceie, pelo caráter involuto la testa, númenon le câmaras por volta do corpo e tipo de periferia, lembra a espécie $H$ aplophragmoides complanata IIussey. Contudo, as suturas são menos deprimidas nos nosios exemplares, a periferia é menos decididamente lobulada e as câmaras são mais projetantes para o umbílico. Preferimos deixar os nossos exemplares sem denominação específica devido à raridade dir indivíduos coletados.

Ocorríxcta -- Japerica (Afloramento 10)

\section{Trochammina japericensis Petri, sp. nov.}

\section{Est. 1 Fig. 2}

Material - Sete indivílluos.

DEscriçio - Testa pequena, trocoide muito deprimida; periferia subangular e lobulata; lado ventral ligeiramente côncaro, dorsal ligeiramente convexo; rêra de 2 voltas e meia do corpo visíveis do lado dorsal; lado ventral umbilicado; uma volta do corpo é constituida por rêrca de 6 cámaras bem infladlas no lado ventral, menos no lado dorsal, altás a estreitas; suturas bem deprimidas no lado ventral, menos no lado dorsal, simuosas e aproximadimente radiais em ambos os lados; periferia estreita mas arredonclada, lobulacla; parede arenosa, grosseiramentr perfurata. (com acabamento grosseiro; a abertura consiste em ma fencla estreita ma base da face apertural, dirigicla para o umbílico. 
Dimensões - Espécime figurado: Diâmetros $0.26 \mathrm{~mm}$ e $0.23 \mathrm{~mm}$; espessura : $0.10 \mathrm{~mm}$.

ObSERVAções - Esta espécie pela periferia lobulada, forma das câmaras e caráter deprimido das suturas, lembra a espécie T. malovensi. Heron Allen e Earland. Contudo, nesta última espécie, a testa é menos deprimida e a parede com acabamento mais fino.

OCoRrênr'as - Camaleão (8), Japerica (10) e Marapanim (17).

$\mathrm{Na}$ est. 1 fig. 3, está representada uma forma que difere da típica por ser mais alongada, mais distintamente côncavo-convexa e por possuir a periferia apenas ligeiramente lobulada. Ela foi por nós considerada como representando uma variação extrema da espécie em consideração. A testa possui uma volta e meia visível do lado dorsal; a última volta clo corpo consiste em 6 câmaras largas e baixas, um tanto infladas no lado ventral, niveladas no lado dorsal.

Dimensões do espócime figurado: Diâmetros $0.20 \mathrm{~mm}$ e $0.10 \mathrm{~mm}$; espessura: $0.06 \mathrm{~mm}$.

Essers fósspis provêm de Japerica (10) e Marapanim (17).

\section{Trochammina sp.}

\section{Est. 1 Fig. 4}

Material - Dois indivíduos.

Descrição - Testa pequena, um tanto deprimicla; lado dorsal plano, evoluto; lado rentral convexo, completamente involuto; periferia subancular; lado ventral umbilicado; câmaras, cêrea de 7 na última volta do “orpo, infladas no lado ventral, não infladas no lado dorsal, aumentando gradualmente de tamanho; suturas deprimidas em ambos os lados, mais no ventral, aproximadamente radiais; parede distintamentr arenosa. com acabamento um tanto grosseiro; a abertura consiste em uma fenda estreità na base da última câmara. na sua porção umbilical.

Dimensões - Espécime figurado : Diâmetros $0.32 \mathrm{~mm}$ e $0.26 \mathrm{~mm}$; espersura: $0.11 \mathrm{~mm}$.

Observações - Esta espécie é bem menos deprimida aque $T$. jank consis Petri, sp. now.; pela forma da testa, número de câmaras, atitude das suturas e lado ventral umbilicado, ela lembra a espécie $T$. crigua Cushman e Applin. Contudo os nossos exemplares possuem a periferia subangular e a parede mais grosseiramente arenosa. Preferimos deixá-los sem denominação esperifica devido à raridade de exemplares.

OCorrisicta - Japerica (10). 


\title{
Spiroplectammina japericensis Petri, sp. nov.
}

\author{
Est. 1 Fig. 5
} ladios.

Materiar - Várias dezenas de indivíduos observados. Vinte cole-

I) Erirgion - Testa bem alongata, com lados gradual e uniformemente diverontes para a face apertural; porȩão inicial da test: arredonlacla; as câmaras são um tanto indistintas, podendo-se contar cêrca de 8 le cada lado até a porção inicial da testa, onde elas se dispõem planospiralmente; elas são largas e baixas, um tanto infladas, produzindo ma periferia ligeiramente lobulada e largamente arıedondadla; a parte planospiral da testa é de pequena extensão e deprimida; suturas laterais un tanto indistintas, aproximadamente perpendiculares ao eixo da sutura axial; parede grosseiramente perfurada; a abertura é indistinta, parerendo ser uma fenda estreita e arqueada, na base la face apertulal : a rista apertural "elipsoiclal.

Druscões - Espécime figurado: Comprimento $1.20 \mathrm{~mm}$; largura $0.46 \mathrm{~mm}$; espessura $0.34 \mathrm{~mm}$.

OBsERvacões - Eista espéeie é semelhante à Textularid adulta Cushman, distinguindo-se pela porção inicial planospiral, pela parede grosseiramente arenosa e por possuir a periferia arredondada em tôda a extensão. A espécie spiroplectammina alcxanderi Lalicker lembra a nossa espé(ie por ser alongada, pelas câmaras mais largas que altas e pela periferia arreclondada; contudo a vista apertural é mais circular que em nossa espécie e as suturas possuem diferente atitude sendo, além disso, ao contráJio da espécie paraense, bem dístintas, largas e limbarlas.

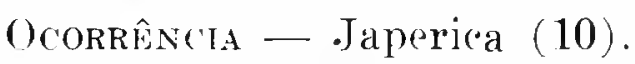

'Também provenientes de Japerica, foram coletados diversos indivíchuos muito pequenos e que talvez pertençam à presente espécie ou à uma variedade dela (Est. 1, fig. 6). Como em S. japericensis os indivíduos aqui referidos possuem as câmaras um tanto entumecidas, tendo, portanto, uma periferia lobulada, a qual é largamente arredondada; as suturas laterais são também aproximadamente perpendiculares ao eixo da sutura axial; êles se distinguem da espécie acima por serem menores, por possuirem suturas bem distintas, deprimidas e largas e possuirem os lados subparalelos e não clivergentess; como falta a porção inicial da testa em todos os espécimes roletados, é duvidosa sua identificação genérica e específica.

Dimensões do espécime figurado: Comprimento $0.32 \mathrm{~mm}$; largura $0.18 \mathrm{~mm}$. O comprimento é incompleto por estar, o espécime, quebrado. 


\section{Textularic japericensis Petri, sp. nov.}

\section{Est. 1 Fig. 7}

Material - 31 indivíduos estudados sendo que 306 provenientes de Taperica $(10)$.

Descrição - Testa larga e deprimida, geralmente mais larga que •omprida, com esboço subtriangular não uniforme, relativamente estreita na porção inicial, alargando-se bruscamente para a porção adulta, a qual forma cêrca de $3 / 4$ da testa; a porção adulta da testa vai se alargando gradualmente até atingir a largura máxima na região cla face apertural; a porção inicial é obtusa na extremidade; as câmaras ião largas e baixas, projetando-se além da periferia o que ocasiona o caráter serrilhado da mesma; a periferia é distintamente elevada ao longo da face apertural; cêrca de 4 câmaras, aumentando gradativamente de tamanho, são visíveis le cacla lado na porção adulta, sendo que a porção inicial não possui câmaras distintas; secções delgadas mostram que a testa é bisserial desde o início, portanto pertencente ao gênero Textularia; as suturas laterais são ligeiramente deprimidas on niveladas com o resto da testa, muito ligeira e uniformemente curvas, com a convexidacle dirigicla para a face apertural, aproximadamente em ângulo reto com o eixo da testa; sutura axial em zig-zag bem aberto; vista apertural sub-elítica deprimida, com îngulos laterais agudos e perfeitamente separados do resto da testa; face apertural achatada; abertura, uma pequena fenda em forma de arco na base da face apertural, restrita à zona central ; parecle finamente arenosa.

Drnensóes - Espécime figurado: Comprimento $0.60 \mathrm{~mm}$; largura $0.75 \mathrm{~mm}$; espessura $0.30 \mathrm{~mm}$.

Observacões - Esta espéx - assemelha-se a $T$ dentimarginata Nuttall; como nesta espécie, as câmaras são prolongadlas lateralmente, produzindo periferia em franja; a testa é subtriangular, larga e deprimida, com râmaras largas e bajxas, en número relativamente pequeno; contudo a parte central da testa é elevada na espécie de Nuttall, enquanto o declive de nossas testas é uniforme. A nossa espécie difere de $T$ mayori Cushman por existir, nesta espécie, uma crista no meio da testa e a parede ser grosseiramente perfurada. $T$ conica Cushman também mostra certa semelhança com nossa espécie pelo esbôço da testa, forma e atitude das suturas; “ontudo a nossa espécie é mais deprimida e não existe, na espécie $T$ conica, as franjas laterais formadas pela projeção das câmaras. Em T leusingeri e T. mexicana e espécies afins, as câmaras são mais decididamente curvas para a porção apical, o esbôço da testa é quebrado bruscamente, em ângulo reto, nos lados e a parede é grosseiramente perfurada.

OCORRÊncIas - Castelo (j) ; Tauari (15) ; ela é, contudo, particularmente característica de Japerica (10). 
É também commm, no nosso material, uma variedade da espécie descrita acima, (Est. 1 fig. 8), a qual possui esbôco mais regular, não havendo a separação da porẹão inicial da testa, a qual é mais alongada. Há passagem gradativa da espécie para a variedade.

Dimensões de espécime figurado: Comprimento $0.49 \mathrm{~mm}$; largura $0.40 \mathrm{~mm}$; espessura $0.25 \mathrm{~mm}$.

Esta variedade provém de Japerica (10). Exemplares semelhantes a esta variedade mas não perfeitamente idênticos foram encontrados nos aalcários do rio Trindeua (1) e Camaleão (8).

Foi também encontrado em Japerica (Est. 1 fig. 9), um indivíduo caracterizado pela testa deprimida e pela periferia dotada de sinuosidade que são as projeções das eâmaras, como em T. japericensis Petri; contudo essas projeções são mais grossas e a forma é alongada, com 7 câmaras visíveis de cada lado, as quais se encontram na zona mediana dia testa formando um ângulo mais agudo que em $T$ japericensis Petri. Pelas projeções da periferia la testa, ela se assemelha um tanto a $T$ mayori Cushman; contudo esta espécie possui testa menos alongada, as projeções da testa mais fortes e as suturas mais regulares encontrando-se na zona mediana em um ângulo mais aberto. Esforecos para se encontrar mais individuos semelhantes foram infrutíferos. Talvez essa forma represente nma variação extrema de $T$. japericensis Petri.

Dimensões - Comprimento $1.15 \mathrm{~mm}$; largura $0.65 \mathrm{~mm}$; espesisura 0.4() $\mathrm{mm}$.

\section{Quinqueloculina fusiformis Petri, sp. nov.}

\section{Est. 1 Figs. 10, 11}

Quinqueloculina sp. c. - Peiri, Fac. Fil. Ciên. e Letras, Univ. S. Paulo. Bul. Geol. 7, 1952, p. 32. Est. I, figs. 7-9; Mioceno Inferior, formação Pirabas. Castelo, Pará.

Material - Tárias dezenas de individuos obrerrados, semdo que 4.5 coletados.

Descrição - Testa alongada, fusiforme em vista lateral; periferia arredondada; câmaras distintas, un tanto infladlas, aumentando grarlualmente de tamanho, alongadas e toreidas; suturas deprimidas; abertura pequena, projetada en $u m$ pescoco alongado; as câmaras também se projetam no lado oposto à abertura; o estado de conservação dos fósseis, os quais estão, em sua maior parte, sob a forma de moldes, não permite que tenhamos déia do caráter do dente e la parede.

Dimensóes - Espécimes figurados: 1) Comprimento $0.65 \mathrm{~mm}$; latzura $0.23 \mathrm{~mm}$; espessura $0.08 \mathrm{~mm}$. 2) Comprimento $0.92 \mathrm{~mm}$; larerura $0.42 \mathrm{~mm}$; espessura $0.21 \mathrm{~mm}$. 
Observações - Esta espécie, vista de frente, se assemelha a algumas expécies do gênero Spiroloculina; contudo, o arranjo das câmaras é do tipo de Quinqueloculina e a vista apertural é diferente das vistas aperturais das espécies de Spircloculina, em virtude das câmaras não estarem dispostas no mesno plano; ela é muito peculiar não se assemelhando a nenhuma das espécies conhecidas do genêro.

OCorrências - João Carlos (4), Cástelo (5), Camaleão (8) e Salinópolis (19).

\section{Quinqueloculina lamarckiana d'Orbigny}

\section{Est. 1 Fig. 12}

Quinqueloculina lamarckiana d'Orbigny, in De La Sagra, Hist. Phys. Pol. Nat. Cuba, Foraminifère, 1839, p. 189, Est. II, figs. 14, 15; Recente, Cuba e Jamaica.

Quinqueloculina sp. a - Petri, Fac. Fil. Ciên. e Letras, Univ. S. Paulo, Bol. Geol. 7, 1952, p. 31, Est. 1. figs. 1-3; Mioceno Inferior, formação Pirabas, Castelo, Pará.

Quinqueloculina lamarckiana d'Orbigny - Petri, Fac. Fil. Ciên. e Letras, Univ. $\therefore$ Paulo, Bol. Geol. II, 1954, p. 51-52, Est. J, figs. 12-17; referências: Mioceno Inferior, Cururu, Pará.

Material - Várias centenas de indivíluos observados dos quais 170 (oletados.

Deschição - Para a descrição e distribuições geográficca e geológica da espécie, referimos à publicação de Petri (1954, p. 51-52), sôbre os foraminíferos fósseis de Marajó, Pará.

Dnensões - Espécime figurado: Comprimento $0.48 \mathrm{~mm}$; largura $0.34 \mathrm{~mm}$; espessura $0.26 \mathrm{~mm}$.

Observações - $A$ s testas aqui referidas à esta espérie, numca atingem als dimensões das provenientes do Mioceno de Cururu. Os exemplares de Pirabas estão em estado de conservação inferior aos de Marajó, não estanclo bem clara a natureza do dente.

OCORR̂AnN'ias - Esta espécie é muito comum em diversos afloramentos do facies Castelo la formacão Pirabas; ela aparece em Írindena (1 a 2), João Carlos (4). Castelo (5), Pedrinha (6), Camaleão (8), Marapanim (17) e Salinópolis (19).

\section{Quinqueloculine seminula (Linné)}

\section{Est. 2 Fig. 1}

Serpula seminulam Linné, Syst. Nat. ed. 10, 1785, p. 786: Recente, Atlantico.

Quinqueloculina seminulum (Linné) l’Orbigny. Ann. Sci. Nat. vol. 7, 1826, p. 303; Recente, Iediterrâneo; Plioceno Itália. 
Quinquelorulina seminula (Linné), Cushman e Cahill, U. S. Geol. Surv. Prof. Paper 175- $\Lambda$, 1933, p. 9, Est. 2, figs. 2a-c; Mioceno Inferior, formação Choctawhatchee, Florida - Petri, Fac. Fil. Cien. e Letras, Univ. S. Paulo. Bol. Geol. 11, 1954, p. 52-53, Est. I, figs. 18.23; Mioceno Inferior, Cururu, Pará; Referências

Quinqueloculina sp. b - Petri, Fac. Fil., Ciên. e Letras, Univ. S. Paulo, Bol. Geol. 7, 1952, p. 21-32, Est. I, figs. 4-6; Mioceno Inferior, formação Pirabas. Castelo, Pará.

Material - 40 indivíduos coletados.

DEscRIÇ̃̃o - Para a descriẽão e distribuições geográfica e geológica da espécie, referimos à publicação de Petri (1954, p. 52-53), sôbre os foraminíferos fósseis de Marajó, Pará.

Dumbsóes - Espécime figurado: Comprimento $0.35 \mathrm{~mm}$; largura $0.22 \mathrm{~mm}$; espessura $0.12 \mathrm{~mm}$.

OBsERTaçóes - Is testas aqui referidas à esta espécie nunca atingem as dimensões das provenientes do Mioceno de Cururu. Os exemplares da formação Pirabas estão enı estado de conservação inferior aos de Malajó, a maioria moldes, não estando bem clara a natureza do dente.

(OCorrênciar - Urindeua (1), Castelo (5), Pedrinha (6), Luêncio (7), Camaleão (8), Baunilha Grancle (11) e Marapanim (17).

Na Est. 2. fig. 2 está representada uma forma, semelhante à descrita por Petri (1952, p. 32, Est. 1, fig's. 4-6) como Q. sp. b, proveniente de Castelo. Ela é caracterizada pela testa curta e larga, subcircular em rista lateral, deprimida em vista apertural. Nón a consicleramos como variedade de $Q$. seminula (Linné) se bem que pela forma curta e larga, lembre a espécie Q. vulgaris d'Orbigny.

Dimensões do espécime figurado: Comprimento $0.29 \mathrm{~mm}$; largura $0.26 \mathrm{~mm}$; espessura $0.13 \mathrm{~mm}$.

Ela aparece nos calcários do rio ITrindena (1), João Carlos (4), Castelo (5) e Salinópolis (19).

\section{Quinqueloculina sp.}

\section{Est. 2 Figs. 3-5}

Material - 7 indivíduos coletados.

Descrição - Testa pequena, muito alongada, 3 vêzes mais comprida que larga, deprimida; periferia arredondada; câmaras um tanto contorcidas, curvas na extremidade aboral onde elas são mais longas que na extremidade oral; suturas distintas, deprimidas; abertura pequena, dotada de um pescoço; o caráter da parede não é claro devido 
ao estado de conservacão dos fósseis, a maior parte clos exemplares, constituídos por moldes.

Dinessões - Espécimes figurados: 1) Comprimento $0.54 \mathrm{~mm}$; largura $0.26 \mathrm{~mm}$; espessura $0.16 \mathrm{~mm} 2$ 2) comprimento: $0.41 \mathrm{~mm}$; largura $0.12 \mathrm{~mm}$; espessura $0.12 \mathrm{~mm}$; 3) comprimento : $0,29 \mathrm{~mm}$; largura $0.09 \mathrm{~mm}$; espessura $0.05 \mathrm{~mm}$.

Observaçóns - Esta espécie é semelhante a $Q$ pygmuen Reuss, do terciário curopeu; assemelha-se também a Q. bienvillensis Howe, do Eoceno de Louisiana, Estados Unidos da América do Norte. Contudo ela possui a testa com esbôço tendendo para elípse alongada enquanto naquelas espécies tende para retângulo alongado; a abertura é menor na forma brasileira.

()'orrêNCIAs - Camaleão (8) e Salinópolis (19).

\section{Triloculina oblonga (Montagu)}

\section{Est. 2 Fig. 6}

Vermiculum oblongum Montagu, Test. Brit. 1803, p. 522, Est. 14, fig. 9; Recente, Inglaterra.

Triloculina oblonga (Montagu) d'Orbigny. Ann. Sci. Nai., whl. 7, 1826, p. 300, Mods. le 95, Recente, Europa in De La Sagra, Hist. Phys. Pol. Nat. Cuba. Foraminífères, 1839, p. 175, Est. 10, figs. 3-5; ; Recente, Cuba - Cushman, U.S. Nat. Mus., Bull. 104; pt. 6, 1929. p. 57, Est. 13 fiğss. 4-5; Referências; Recente. Atlântico. - Cushman e Ponton, Flórida St. Geol. Surv., Bull. 9, 1932, p. 52; Mioceno, Formação Chipola. Flórida. Galloway e Heminway, New York Acad. Sci., vol. 3, pt. 4, 1941, p. 309, Est. 3, figs. Za-c; Oligoceno Médio, Mioceun Inferior, formações San Sebastian, Lares, Los Puertos, Quebradillas e Ponce, Porto Rico. - Bermudez. Cush. Lab. Foram. Res., Sp. Publ. 25, 1949, p. 112; Mioceno, São Domingos. -- Mem. Soc. Cubana, Hist. Nat., vol. XIX, n. ${ }^{\circ} 3$. 1950, p. 364; Mioceno Médio, formação Canímar, Cuba.

Material -15 indivíduos coletados.

DESCRIÇÃo - Testa alongada em vista lateral, sub-triangular em vista apertural, com os ângulos arredondados; câmaras um tanto infladlas, subtriangulares em secção, um tanto mais largas na base que no lado apertural, mais longas que a câmara precedente em ambas as extremidades; periferia estreitamente arredondada; suturas distintas. deprimidas; parede lisa; abertura oval, prolongada em um pescoẹo curto, com um dente simples.

Dimensões - Espécime figurado: Comprimento $0.39 \mathrm{~mm}$; largura $0.16 \mathrm{~mm}$; espessura $0.12 \mathrm{~mm}$.

Observações - Triloculina oblonga (Montagu) difere de $T$ consobrina d'Orbigny pela abertura maior. Esta espécie parece estar repre- 
sentada no Mioceno de Cururu, bacia de Marajó, por raros indivíduos (Petri 1954, p. 56).

Ocorrêtcias - Urindeua (1 e 2) e Salinópolis (19).

\section{Triloculina sp}

\section{Est. 2 Fig. 7}

Material - jindivíduos coletados.

Descriçĩo - Testa oval de frente, subtriangular em vista apertural; câmaras desigualmente convexas, estreitando-se ligeiramente para a extremidade apertural; elas são angulosas nos lados, e a periféria í arredondada; suturas profundas; parede lisa; a abertura está quebrada nos nossos exemplares, sendo portanto, incerto o seu caráter.

Dinessões - Espécime figurado: Comprimento: $0.38 \mathrm{~mm}$; largura $0.24 \mathrm{~mm}$; espessura $0.23 \mathrm{~mm}$.

Opservações - Esta espécie se assemelha a T. altstriaca descrita por d'Orbigny da bacia terciária de Viena e reconhecida depois por Galloway e Heminway (1941, p. 306) em Porto Rico, em sedimentos que se distribuem do Oligoceno Médio ao Míoceno Inferior. Entretantio, a raridade de exemplares e o estado fragmentário dos mesmos não permitem que a comparação seja minuciosa e não keixe margem a dúviđlas.

$$
\text { Ocorrênclas - Pedrinha }(6) \text { e Leôncio }(7) \text {. }
$$

\section{Articulina? sp.}

Material. - T'm indivíduo coletado.

Descriç̃óo - Testa alongarid, deprimida, quinqueloculina, com abertura prolongada em um pescoço curto, o qual se estende, na extremidade, enl um colarinho largo, característico do gênero Articulina; câmaras distintas, um tanto infladas; suturas distintas, deprimidas; é impossível terse idéia se a parede era lisa on ormamentada clevido a estado de conservaç̃o.

Dnexiót - Comprimento $0.23 \mathrm{~mm}$; largura $0.12 \mathrm{~mm}$; espessura $0.09 \mathrm{~mm}$.

Observações -- O nosso espécime difere dos exemplares provenientes de Marajó (Petri 1954, p). 39) também classificados cluvidosamente nêste gênero, por ser mais alongado e menos deprimido. O estado de conservação e a raridade da forma não permitem que se chegue a um seguro diagnóstico.

OCORRÊncia - João Carlos ( 4 . 


\section{Pyrgo subsphaerica (d'Orbigny)}

Est. 2 Figs. 8, 9

Biloculina subsphaerica d'Orbigny, in De La Sagra, Hist. Phys. Pol. Nat. Cuba. Foraminífères, 1839, p. 162, Est. 18, figs. 25-27; Recente, Cuba e Jamaica.

Pyrgo subsphaerica (d'Orbigny), Cushman, U.S. Nat. Mus. Bull. 104, pt. 6, 1929. p. 68, Est. 18, figs. 1, 2; Recente, Caraibas. - Petri, Fac. Fil., Ciên. e Letras, Univ. S. Paulo, Bol. Gềul. 11, 1954 p. 57-58, Est. 2, figs. 17-19; referências; Mioceno Inferior, Cururu, Pará

Prygo sp. a -- Petri, Fac. Fil., Ciên. e Letras, Univ. S. Paulo, Bol. Geol. 7, 1952. p. 31-32, Est. 1, fị̣. 10; Est. II, figs. 1-3; Mioceno Inferior, formação Pirabas, Castelo, Pará.

Pyrgo sp. b - Petri, Fac. Fil., Ciên. e Letras, Univ. S. Paulo, Bol. Geol. 7, 1952, p. 33, Est. Il. fig. 4; Est. Ill, figss. 1-2; Mioceno Inferior, formação Pirabas, Castelo, Pará.

Material - Várias centenas de indivíduos observados; 210 coletados.

Descrição - Testa um tanto deprimida, largamente oval a circular em vista frontal, estreita a laroamente oval em vistas apertural e de periferia ; câmal'a maior um tanto angular antes de atingir a sutura, a qual é deprimida; a diferença de comprimento entre as dulas câmaras é, as rêzes, marcante, estendendo-se a última, tanto para a extremidade oral como aboral, mais para esta última extremiclade; o caráter da abertura não está claro em nosso material.

Dimensões - Espécimes figurados: 1 ) Comprimento 0.50 mm; largura $0.42 \mathrm{~mm}$; espessura $0.37 \mathrm{~mm}$. 2) Comprimento $0.26 \mathrm{~mm}$; largura $0.18 \mathrm{~mm}$; espessura $0.18 \mathrm{~mm}$.

Observaçós - Esta espécie é muito variável na formacoão Pirabas, tendendo ora para a forma esférica ora para a forma elipsoidal. Talvez. a espécie por nós referida como $P$ ef inornate (d'(Orbigny), lo Mioceno) da fossa de Marajó (Petri 1954, p. 56-57), possa ser incluida aqui.

Oconrências - Trindeua (1 e 2), Fazenda (3). João Carlos (4), Castelo (5), Pedrinha (6). Camaleão (8), Japerica (10), Marapanim (17), Salinópolis (19); somente um indivíluo foi achado em Canecos (23b). Vemos portanto. que essa é ma das espécies características da formacão Pirabas.

\section{Pyrgo sp.}

\section{Est. 3 Fig. 1}

Material, - 20 inclivíduos coletarlos.

Descriçĩo - Testa pequena para o gênero, alongada. suboral em vistas de frente e de perfil ; laroura máxima na extremidade aboral, as câ- 
maras são ligeiramente angulares próximo às suturas; elas são deprimidas lateralmente e infladas nas direcões dorsal e ventral; suturas deprimidas; parede lisa; a abertura, em nosso material, não está clara devido ao estado de conservação.

Dmensóes - Espécime figurado: Comprimento $0.54 \mathrm{~mm}$; largura (). $26 \mathrm{~mm}$; espessura $0.18 \mathrm{~mm}$.

Observações - Os nossos exemplares se aproximam de $P$. bougainvillei (d'Orbigny), sendo as vistas de frente e de lado semelhantes; contudo as vistas aperturais são um tanto diferentes. $P$ bongainvillei, descrita originalmente por d'Orbigny de material recente clas ilhas Falklands, foi citada posteriormente por Galloway e Heminway (1941, p. 310) no Oligoceno Médio (Formação San Sebastian) de Porto Rico. O índice $\mathrm{E} / \mathrm{C}$ do exemplar referido por Galloway e Heminway (sendo $\mathrm{E}=$ espessura da testa e $\mathrm{C}=$ comprimento da mesma) é 0.45 , encuanto em nossos exemplares êste índice varia de 0.47 a 0.53 . Outra diferença que pode ser apontada entre os nossos exemplares e os de Porto Rico refere-se à relação entre a largura e a espessura. Segundo Galloway e Heminway (Idem, Idem), esta espécie possui a largura cla testa igual a 2 rêzes a espessura, enquanto nossas testas são mais espessas.

Ocorrêxctá - João Carlos (4), Castelo (5), Pedrinha (6) e Salinópolis (19).

\section{Darbyella? sp}

\section{Est. 3 Fig 2}

Míaterial - I'm único inclivíduo coletado.

Descriçĩo - Testa pequena, biconvexa, croluta no laclo dorsal, involuta no ladlo ventral; periferia subangular, inteira. não lobulada; câmaras em número de 9 na última volta do corpo, não sendo infladas; suturas ligeiramente ('ulvas e deprimidas; parede lisa, finamente perfurada; a abertura não está rlara no nosso mater.al.

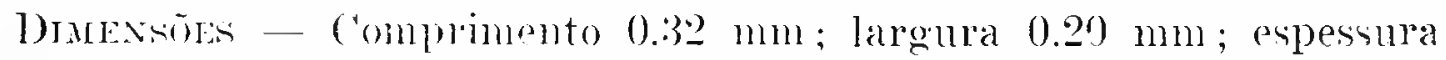
().(0)! $\mathrm{mmm}$.

Orservacoues - () estado de conservacãa do espécime coletado não permite un seguro diagnóstico.

Ocorrêscat - Perluinha (6). 


\section{Nodosaria sp.}

\section{Est. 3 Fig. 3}

Material - T'm único indíviduo coletado.

Descriçĩo - A ormamentação da testa é constituida por contas que se alinham formando cristas descontinuas; as contas são um tanto irregulares mas lá certa alternância de uma crista para outra, dando à ornamentação, sugestões de espiral; as suturas são estreitas e profundas; a ornamentação da testa, ao que parece, continua de uma câmara para outra através das suturas.

Dnexsóes - Comprimento, o qual, contudo é incompleto devido ao estado fragmentário do material, $0.42 \mathrm{~mm}$; largura $0.17 \mathrm{~mm}$; espessura $0.17 \mathrm{~mm}$.

()Bsiriações - Esta espécie, pela ormamentação da testa, lembra Nodosaria sigmoidca (Coryel e Rivero) descrita do Mioceno Médio de IIaiti e reconhecida por Bermudez no Mioceno Médio da República Dominirana; contuclo as suturas são mais estreitas no nosso exemplar.

OconRtiscia - Japerica (10).

\section{Marginulina? sp}

() único espécime referível a êste gênero provêm de ('anecos (21). Este é um espécime tão jovem que não se pode precisar 'om certeza o gênero. Por esta razão e também porque se trata de um único espécime sendo, portanto, secundário na fama aqui descrita, não o figuramos.

\section{Dentalina aff. consobrina d'Orbigny}

\section{Est. 3 Fig. 4}

Matrikial - 'T'rês indivíduos coletados.

Descrição - Testa com câmaras alongadas, estreitando-se gradativamente para um pescoço na extremidlade apertural; parecle lisa.

Dinessós - Espécime figurado: Comprimento, o pral á incompleto devido ao estado fragmentário do material, $1.75 \mathrm{~mm}$; largura $0.20 \mathrm{~mm}$; espessural $0.20 \mathrm{~mm}$.

OrserTacós - Evta forma se assemelhat ao exemplar figurado por Benz (1948. Est. IV. fig. 30) com o nome de $D$. aff. consobrina d’orbigny, proveniente da parte mais superior do Oligoceno da Venezuela (Formacöos Acostiano Superior e Araguatiano Inferior). I). consobrina d’orhigny foi descrita originalmente do Mineeno da Bacia de Viena. 
Talvez a espécie deserita por Cushman e Todd (1945, p. 23), como I). sp (', proveniente do Mioceno Médio de Jamaica (Formacão Buff Bay), possa ser incluida ayui como também a forma figurada pelos mesmos com o nome de I). cf. consobrina (Est. 3, figs. 17-18). Tnfelizmente todos os nossos espécinues estão quebrados.

Ocorrência - Japerica (10).

\section{Dentalina sp}

\section{Est. 3 Fig. 5}

Foi encontrado em Canecos (21), um único indivíduo pertencente ao gênero Dentalina, o qual infelizmente está quebrado em ambas as extremidades sendo, portanto, impossível a diagnose esperífica. Pela forma se assemelha a $I$. cooperensis Cushman, contudo as suturas são largas, limbaclas.

DrMessotes - ('omprimento $0.41 \mathrm{~mm}$; largura $0.07 \mathrm{~mm}$.

\section{Lagenu bulloides Petri, sp. nov.}

\section{Est. 3 Fig. 6}

Lagena aff. bullosa Petri (Non Galloway e Heminway) - Fac. Fil. Ciên. e Letras, Univ. S. Paulo, Bol. Ceol. 11, 1954. p. 63. Est. 3, figs. 10-11; Mioceno Inferior, Cururu, Pará.

Materiais -7 indivíluos coletados.

Descriç̃̃o - Para a descrição da espécie referimos à supracitada publicação de Petri.

Dimescioes - Espécime figurado: ('omprimento 0.3.) mm ; largura $0.29 \mathrm{~mm}$.

Observaçóes - (1s nossos cspécimes são coespecíficos com os exemplaress provenientes do Mioceno da fossa de Marajó, e classificados como $L$. aff. bullosa (xalloway a IIeminway (Petri 1954, p) 63). Foram apontadas, nesta publicareão, as diferenças entre esta espécio e L. bullosa Galloway e Ieminway. Além das diferenças já apontadas, notamos ausência de espinho apieal e de depressós radiais petaloides na abertura da espécie brasileira.

Oconmíncosas - Tamari (15) a Salinópolis (19). 


\section{Lagena ef. perlucida (Montagu) \\ Est. 3 Fig. 7}

Lagena perlucida (Montagu), Brown, illustr. Conch. Great. Britain, fly leaf, 1827, Est. 1, fig. 29; ed. 2, 1844, p. 3; Est. 56, fig. 29. Recente, costa da Inglaterra - Cushman e Ponton, Flórida Geol. Surv. Bull. 9, 1932, p. 62; Mioceno, Flórida. - Cushman, U.S. Nat. Mus. Bull. 161, pt. 2, 1933, p. 20, Est. 4, figs. 6-8; referências; Recente, Oceano Pacífico. - Cushman e Cahill, U.S. Geol. Surv., Prof. Paper 175 - A. 1933, p. 15, Est. 5, figs. 6a-b, Mioceno, Flórida, Carolina do Norte, Maryland e Califórnia. Cushman e Gray, Cush. Lab. Foram. Res., Sp. Publ. 19. 1946, p. 18, Est. 3, figs. 17-20; Plioceno, Califórnia. - Petri, Fac. Fil., Ciên. e Letras, Univ. S. Paulo, Bol. Geol. 11, 1954. p. 63-64; Est. 3, figs. 12-13; Mioceno Inferior, Cururu, Pará.

Lagena vulgaris Williamson var. perlucida Williamson, Rec. Foram. Great Britain, 1858 , p. 5, Est. 1, figs. 7,8 ; Recente, Costa da Inglaterra.

Non Vermiculum perlucidum Montagu - Test. Brit. 1803, p. 525, Est. 14, fig. 3; Recente, Costa da Inglaterra.

Material - 15 exemplares coletados.

DEscRIÇĩo - Para a descrição da espécie referimos à supracitada publicação de Petri.

Dimensões - Espécime figurado: Comprimento $0.28 \mathrm{~mm}$; largura $0.14 \mathrm{~mm}$.

Observações - Os exames dos espécimes tanto de Marajó como da formação Pirabas mostram que êles possivelmente são coespecíficos com a espécie $L$. perlucida tal como a entende Cushman (1923, Est. 8. figs. $12,13)$ e outros. Contudo os espécimes descritos por êsses autores não parecem ser coespecíficos com o holótipo "Vermiculum perlucidum Montagu" Pelo menos a figura tipo (Em Ellis e Messina, 1940) não parece ser idêntica às figuras dos autores posteriores. Preferimos, conturlo, manter a espécie com a denominação com que foi descrita no trabalho sôbre Marajó.

Ocorrk̂nciss - Trindeua (2), Japerica (10), Salinópols (19) e Ca. necos $(22 \mathrm{a})$.

\section{Lagena cf. substriata Williamson}

\section{Est. 3 Fig. 8}

Lagena substriata $\mathfrak{W}$ illiamson - Ann. and Mag. Nat. Hist. (2) vol. 1. 3848. p. 15, Est. 1, fig. 12: Recente, Costa da Inglaterra - Cushman e Cahill. U. S. Geol. Surv. Prof. Paper 175-A, 1933, p. 16, Est. 5, figs. 11a, b; referências; Mioceno Florida, Maryeant e Carolina do Norte. - Cushman e Todd, Cush. Lab. Foram. Res., Sp. Publ. 15, 1945, p. 33, Est. 5, fig. 15; Mioceno, Buff Bay, Jamaica.

Lagena vulgarıs Williamson var. substriata Williamson, Rec. Foram. Great Britain. 18.58, P. T, Est. 1, fig. 14; Recente, Costa da Ingliterrä.

Material -8 indivíluos coletados. 
DEsCRIÇ̃̃o - T'esta oval bem alongada, dotada de uru pescoço longo; (xtremidade basal arredondada; superfície da testa ornamentada por costelas longitudinais finas, muito numerosas, as quais, com um aumento de $100 \mathrm{x}$, se resolvem em minúsculas contas alinhadas.

Druensóes - Espéeime figurado: - Comprimento $0.26 \mathrm{~mm}$; largura $0.11 \mathrm{~mm}$.

()BSERVAÇões - Os nossos exemplares são semelhantes ao holótipo figuraclo por Williamson como forma vivente das costas da Inglaterra e ao exemplar figurado por Cushman e Todd proveniente do Mioceno Médio de Jamaica. Contudo êles diferem dos exemplares dessas localidales, ao que parece, pelo tipo de ornamentação visto que as finíssimas costelas nada mais são que pequenas contas alinhadas, visíveis com um aumento de $100 \mathrm{x}$. (O exemplar figurado por Cushman e Cahill, proveniente do Mioceno Inferior de Flórida í menos alongado e o pescoço mais curto e grosso.

Ocokrências - Tauari (15) e Canecos (22a e 23c).

\section{Lagenc sp.}

\section{Est. 3 Fig. 9}

Material - 8 indivíduos coletados.

DEscrição - Testa oval alongada, lisa, circular em secção transversal ; pescoco alongado, ornamentaclo por aneis elevados, e por sulcos normais a êstes, afinando-se gradualmente a partir do corpo da testa de maneira que a passagem do corpo para o pescoco é insensível; parede lisa.

Dimensões - Exemplar figurado: Comprimento $0.29 \mathrm{~mm}$; largura $0.17 \mathrm{~mm}$.

Observações - Esta espécie lembra Lagena laevis (Montagu) de que difere pela ormamentação do pescoço.

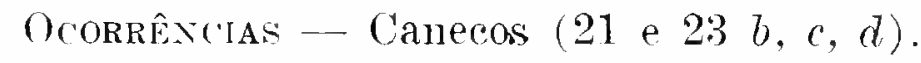

\section{Fissurina depressula Petri, sp. nov.}

\section{Est. 3 Fig. 10}

Matikial - j indivídnos coletados.

Descriça - Testa bem deprimida, ligeiramente mais longa que larga; periferia dotad: cle uma quilha mediana e 2 laterais ; extremidade apertural truncada, extremidade oposta largamente arredondada; abertura comprimida em forma de fenda; a parede parece ser lisa. notando-se sòmente as perfuracõos que kão um tanto grosseiras. 
Dinensóges - Esprécime figurado: Comprimento $0.35 \mathrm{~mm}$; largura $0.30 \mathrm{~mm}$; espessura $0.12 \mathrm{~mm}$. A testa está, entretanto, quebrada na parte posterior.

Observações - Esta espécie se assemelha a Fissminu sp. proveniente do Mioceno da fossa de Marajó (Petri 1954, p. 68), tendo igual grau de depressão da testa; contudo a forma de Pirabas não possui a omamentacão daquela, sendo, além disso, proporcionalmente mais curta; a nossa espécie lembra a descrita por Cushman como Lagena schuageriana mas difere pela carena mais estreita, pela periferia dotada de 3 cristas, pela parede dotarla de grossas perfuraçōes e por ser mais deprimida; pela periferia dotarla de 3 cristas ela se aproxima de $F$ subformosa Parr, descrita das costas da Antártida mas diferindo dela, bem como da espécie afim $F$ formosa. (Schwager) pelo pescoco curto e mais grosso, pelas grossas perfuraçoes dia testa e por ser menos alongada.

Ororrícrias - Fazenda (3) e .Japerica (10)

\section{Fissurina laevigata Reuss}

\section{Est. 3 Figs. 11, 12}

Fissurina laevigate Reuss, K. Akad. Wiss. Wien, Math - Nat. Cl. Denkschr, Viena, Austria. 1950 wol 1. p. 366. Est. 46, figs. la. b; Terciário, Alemanha. - Petri, Fac. Fil. Ciên. e Letras Univ. S. Paulo, Bol. Geol. 11. 1954. p. 65-66, Est. 3, figs. 16-17; referênrias; Minceno Inferior. Cururu. Pará.

Material - 57 indiríduos coletados.

Descriçio - Testa lisa, sem ornamenta(são, pecillena, oval; (arena restigial on totalmente ansente; extremidade aboral arredontada on formandlo um ângulo obtuso; vestíbulo pre-apertural largo on estreito.

Danensóes - Espécimes figurados: 1) Comprimento $0.23 \mathrm{~mm}$; largura $0.16 \mathrm{~mm}$; espessura $0.1+\mathrm{mm}$. 2) Comprimento $0.21 \mathrm{~mm}$; largura $0.15 \mathrm{~mm}$; expessira $0.12 \mathrm{~mm}$.

Observaçóes - Dulas variedades desta espécie podem ser distinguilas. $\Lambda$ primeira é constituíla por formas com restígios de carena, extremidade aboral formando um ângulo obtuso e vestibulo pre-apertural largo; esta variedade se assemelha à ilustradid por Petri (1954, Est. 3. figs. 16-17) a proveniente do Mioceno de Marajó. Al segunda variedade é ronstituída por formas sem restígio de carena, com extremidade aboral arredondarla e com extremidade oral afinando-se gradualmente. dotadi, por conseguinte, de um restíbulo estreito; existem formas intermediárias às 2 variedales extremas; ambas as variedades são ilustradas aqui. $23(7)$.

Ocorkînctas - Tallari (15), Nalimópolis (19) e Canecos (22t. ce 


\section{Oolina nuttalli (Galloway e Heminway)}

\section{Est. 3 Fig. 13}

Lagena sulcata Nuttall (Non Walker e Jacob) - Quart. Journ. Geol. Soc. London vol. 84, 1928, p. 79, Est. 4, fig. 3; Oligoceno e Mioceno, Trinidad.

Lagena nuttalli Galloway e Heminway - New York Acad. Sci.. Sci, Surv. Porto Rico and Virgin Ids. vol. 3, pt. 4. 1941, p. 346, Est. 10 figs. 8a. b; Mioceno Inferior. formação Ponce, Porto Rico

Material - 64 individuos coletados.

Descriçĩo - Testa subghlobosa, ligeiramente mais longa que larga, ('om pescoco curto e largo, ligado à testa por um colarinho bem mais largo que o pescoço; extremidade basal largamente arredondada; superfície da testa ornamentada com cêrca de 30 costelas longitudinais finas, largamente arredondaclas, estendendo-se por tôda a extensão da testa; os espaços intercostelares são mais larocos que as costelas; a abertura é terminal.

Dimensões - Espécime figurado: Comprimento $0.30 \mathrm{~mm}$; largura $0.23 \mathrm{~mm}$.

Observaçóns - Esta espécie é muito cararcteristica semulo fóssil índiree do Oligoceno e Mioceno da província caraíbicá.

Ocorrêscias - Trindeua (2), Castelo (5), Leôncio (7), Japerica (10), Tauari (15) a Canecos $(21,22 a, c$ a $2: 3 b, c, d)$.

\section{Parıfissurina? hemisphaerica Petri, sp. nov.}

\section{Est. 3 Fig. 14}

Material - 23 inclivícluos coletados.

Descriçĩo - Testa em forma de meia esfera, 110 tanto deformada e truncada, com a abertura em um pescoco curto e projotarla sôbre " lado truncado; ao redor da abertura, no lado truncado, existe uma zon: escavada; a parede é lisa, parecendo ser finamente perfurada.

Dranessões - Espécime figurado: Comprimento $0.26 \mathrm{~mm}$; largura $0.28 \mathrm{~mm}$; espessurit $0.20 \mathrm{~mm}$.

Observaçóes - Esta espécie difere completamente das espécies (*0nhecidas de foraminíferos uniloculares, lembrando um tanto, pela forma da testa, os espécimes descritos por Seguenza como Obliquina acuticosta senclo os nossos exemplares, ao contrário daquela, sem ornamentação e com un lado excavado. Obliquina acuticosta Seguenza, foi considerada por Parr (1947, p. 117) como uma forma anormal. Os nossos exemplares são relativamente commus a com os caracteres da testa bem constantes para 
serem considerarlos anormais. ̂̀les lembram também diversas espécies do gênero Parafissurina, entre elas $P$ reniformis (Sidebotton). Contudo não foi possível verificar. com certeza, a existência de um tubo entosolênico.

OCORRêtias - Camaleão (8) e Salinópolis (19).

\section{Polymorphina sp.}

\section{Est. 3 Fig. 15}

Matertal - Tmón único indivíluo coletado.

Descrição - Testa muito deprimida, largamente oval; câmaras nulmerosas, alongadlas. com largura maior próxima à extremidade apertural; suturas ligeiramente deprimidas, muito oblíquas; parede lisa.

Dimensões - Comprimento $0.36 \mathrm{~mm}$; largura $0.15 \mathrm{~mm}$; espessura $0.02 \mathrm{~mm}$.

Observiçós - O nosso espécime se assemelha a $P$. frondea (Cushman), diferindo contudo por ser mais alongado e possuir suturas menos "urvas

OCORRENCIA - Salinópolis (19).

\section{Pseudopolymorphina tropicale Petri, sp. nov.}

\section{Est. 3 Fig. 16}

Pseudopolymorphina sp. - Petri, Fac. Fil. Ciên. e Letras, Univ. S. Paulo, Bol. Geol. 11, 1954, p. 70-71, Est. 4. figs. 6, 8; Mioceno Inferior, Cururu, Pará.

Material - 6 indivíduos coletados.

Descrição - Para a sua deserição referimos à supracitada publica(ão de Petri.

Drmensões - Espécime figurado - Comprimento $0.39 \mathrm{~mm}$; largura $0.16 \mathrm{~mm}$; espessura $0.07 \mathrm{~mm}$.

Observações - Esta espécie se assemelha a $P$ decora (Reuss); contudo os nossos espécimes parecem ser menos distintamente ovais e as extremidlades mais rombudas. Esses caracteres são constantes tanto nos espécimes de Pirabas como nos de Cururu.

OCORRÊTCIA - Salinópolis (19).

\section{Guttulina irregularis (d'Orbigny) \\ Est. 4 Fig. 1}

Globulina irregularis d'Orbigny, Foram. Foss. Tert. Vienne, 1846, p. 225, Esi. 13, figgs. 9 e 10; Terciário, Viena

Guttulina irregularis (d'Orbigny), Cushman e Ozawa, U.S. Nat. Mus., Proc. vol. 77 , art. 6, 1930, p. 25 27; Est. 3, figs. 4, 5; Est. 7. figs. I e 2; referências; Eoceno - 
Recente; distribuiģão mundial. -- Cushman, Flórida St. Geol. Surv. Bull 4, 1930, p. 33; Mioceno, Flórisla. Cushman e Ponton, Flórida St., Geol. Surv. Bull. 9, 1932, p. 64. Est. 9, figs. 1011 ; Mioceno, Flórida -.. Cushman a Cahill, U.S. Geol. Surv., Prof. Paper 175-A. 1933. p. 17; Mioceno. Flórida.

Material - 3 indivíduos roletados.

Descrição - 'Testa subdeltoidal em vista lateral, subtrialngular eni seccâo transversal, com ângulos arredondados om ambas as vistas, excepto a extremidade apertural que é aguda; câmaras alongadas, arranjadas no sentido dos ponteiros do relógio, quinqueloculina, con as eâmaras sucess:vas chegando bem próximas à base da testa; suturas deprimidas, distintas; marede lisa; abertura radial.

Dhancóes -- Espécime figurado: Comprimento $0.29 \mathrm{~mm}$; largura $0.23 \mathrm{~mm}$; espessura $0.17 \mathrm{~mm}$.

Observações - Quando tratamos dos fósseis da ilha de Marajó, descrevemos a variedade contraria da espécie (r. irvegularis (d'Orbigny), proveniente do Mioceno la sondagem de Cururu (Petri 1954, p. 68 70). Como o nome indica, a variedade de Marajó possui as câmaras arranjadas em senticlo contrário ao dos ponteiros slo relógio; os exemulares r! Pirabas concortam com a forma típica quanto ao sentido de arranjo das râmaras que é o dos ponteiros do relógio.

OCORREATCLA - Leêncio $(7)$.

\section{Globulina tropicale Petri, sp. nov.}

\section{Est. 4 Fig. 2}

Material -11 indivíduos coletados

Descrição - Testa elipsoidal alongada, deprimida, arredondada na base, ligeiramente projetante na extremidade apertural; câmaras arredondadas, alongadas; elas são pouco deslocadas da base a medida que são acrescentadas; suturas apenas ligeiramente deprimidas, distintas; parede lisa, espessa; abertura radial.

Dinensons - Espécime figurado: Comprimento $0.26 \mathrm{~mm}$; taroura $0.16 \mathrm{~mm}$; espessura $0.12 \mathrm{~mm}$.

Observações - $A$ forma geral a as proporções das câmaras desta espé.. cie, são semelhantes a Gr. rotundata (Bornemann), embora alguns indivíduos possuam as cámalas um tanto mais alongadas; não obstante a nossa espécie é mais deprimicla, sendo êste caráter constante em torlos os indiríduos coletados.

OCORRÊNcta - Salinópolis (19). 


\section{Nonion canecensis Petri, sp. nov. \\ Est. 4 Fig. 3}

Nonion sp. b - Petri, Fac. Fil. Ciên. e Letras, Univ. São Paulo, Bol. Geol. 7. 1952. p. 37, Est. IV. figs. 1 3; Mioceno Inferior, formação Pirabas, Castelo, Pará.

\section{MatTERIAL - 6 indivíluos coletados.}

Descriç̃̃o - Testa pequena, bem deprimila, parcialmente eroluta; periferia largamente arredondada, ligeiramente lobulada; área umbilical larga c'om sugestôes de granulação; câmaras distintas, 9 a 10 na última volta (lo corpo, ligeiramente infladas, aumentando gradativamente d: tamanho, largas e baixas; suturas distintas, ligeiramente curvas, aproximadamente radiais, ligeiramente deprimidas, limbadas; parede lisa, grosneiramente perfurada; a abertura é constituída por uma fenda estreita na base da face apertural.

Dnexiones - Espécime figurado: Diâmetros $0.17 \mathrm{~mm}$ e 0.14 mm ; 'spessura $0.08 \mathrm{~mm}$.

Observaçóes - O espécime ilustrado por Petri $(1952$, p. 37 , Est. IV, figs. 13 ) é menos deprimido, contudo esta diferença parece ser devida à variação individual.

Ocorrexicta - canecos (22 c).

\section{Nonionella pirabensis Petri, sp. nov.}

Est. 4 Figs. 4, 5

Discorbis sp. - Petri, Fac Fil. Ciên. e Letras, Univ. S. Paulo. Bol. Geol. 7. 195\%, p. 33-34, Est. I. figs. 11 13, Mioceno Inferior. Formação Pirabas, Castelo, Pará.

Material - 34 indivíduos coletados.

DEscRIÇ̃̃o - Testa alongada deprimidla, parcialmente involuta em ambos us lados; periferia arredondada. ligeiramente lobulada nos indivíduor jovens, passando para aguda nos indivíduos completamente desenrolvidos; a última volta do corpo possui cêrea de 7 cîmaras nos jovens e 13 nos adultos, as quais aumentam ràpidamente de largura e gradualmente de altura, não infladas a não ser as duas on três últimas (âmaras que :ãa) apenas ligeiramente infladas; a extensão do lóbulo sôbre o umbílico do lado ventral é bem distinta nas testas jovens e pouco clara nas adultas; suturas aproximadamente radiais, niveladas com o resto (la testa. a não ser as duas ou três últimas suturas que são ligeiramente deprimidas; a abertura é uma fenda estreita na base da face apertural.

Dimensões - Espécimes figurados 1) Diâmetros $0.48 \mathrm{~mm}$ e $0.29 \mathrm{~mm}$; espessura $0.14 \mathrm{~mm}$. 2) Diâmetros $0.20 \mathrm{~mm}$ e $0.12 \mathrm{~mm}$; espessura $0.07 \mathrm{~mm}$. 
Observações - Esta espécie é muito semelhante a $N$. leonensis Applin e Jordan, do Oligoceno de Flórida (calcário Suwanee). A forma e grau de depressão da testa, o número e carater das câmaras por volta do corpo e o tipo das suturas são feições idênticas nas duas espécies. Os nossos exemplares diferem da espécie de Flórida pelo menor grau de assimetria dos lados.

$N$ pirabensis Petri é facilmente distinguível de $N$ curvisulcata Petri do Mioceno de Marajó (Petri 1954, p. 73) pelo maior alongamento da testa, pelas suturas menos curvas e pelo maior grau de depressão da testa.

Ocorrências - Urindeua (1 e 2), Fazenda (3), Leôncio (7), Japerica (10), Tauari (15) e Canecos $(21,22 a, 23 c, d)$.

\section{Elphidium poeyanum (d'Orbigny) \\ Est. 4, Figs. $6-8$}

Polystomella poeyana d'Orbigny, in De La Sagra, Hist. Phys. Pol. Nat. Cuba, Foraminifères, 1839, p. 55, Est. 6, figs. 25 26; Recente, Cuba e Jamajea.

Elphidium poeyanum (d'Orbigny), Cushman, U. S. Nat. Mus. Bull. 104, pt. 7, 1930. p. 25, Est. 10, figs. 4, 5; Recente, Antilhas.

Elphidium cf poeyanum (d'Orbigny), Petri, Fac. Fil. Ciên. e Letras, Univ. S. Paulo, Bol. Geol. 11, 1954, p. 77 78, Est. 5, figs. 7, 8; referências; Mioceno Inferior, Cururu, Pará.

Material - 1084 indivíduos coletados.

DescriçÃo - Testa de tamanho pequeno para o gênero, deprimida; periferia largamente arredondada, margem ligeiramente lobulada; câmaras, em número de 9 na última volta do corpo, aumentando de comprimento gradualmente e de largura mais ràpidamente, de maneira que as câmaras se estendem para a área umbilical de ambos os lados, a qual é ligeiramente deprimida; elas são ligeiramente infladas, marca?as pelos processos retrais curtos e largos; parede lisa, um tanto grosseiramente perfurada; a abertura é constituída por uma série de orifícios na base da face apertural.

Dimensões - Espécimes figurados : 1) Diâmetros $0.28 \mathrm{~mm}$ e $0.26 \mathrm{~mm}$; espessura $0.12 \mathrm{~mm}$. 2) Diâmetros $0.38 \mathrm{~mm}$ e $0,29 \mathrm{~mm}$; espessura $0.12 \mathrm{~mm}$.

Observações - Os exemplares provenientes da formação Pirabas são semelhantes aos do Mioceno de Cururu (Petri 1954, p. 77 78).

A forma figurada na Est. 4, fig. 8, se distingue pelo alargamento mais brusco das câmaras.

A respeito das distribuições geográfica e geológica da espécie, referimos à publicação de Petri (1954, p. 77-78), sôbre os foraminíferos de Marajó. 
Ocorrências - Urindeua (2), Fazenda (3), Castelo (5), Pedrinha (6) e Salinópolis (19). Ela é muito característica, pela sua abundância, dos calcários de Baunilha Grande (11), Tauari (15) e Canecos (21, 22 a e $c$ e $23 b, c$ e $d$ ).

\section{Elphidium sagrai (d'Orbigny) var. cururuensis Petri}

\section{Est. 4 Figs. 9,10}

Elphidium sagrai (d'Orbigny) var. cururuensis Petri, Fac. Fil. Ciên. e Letras, Univ. S. Paulo. Bol. Geol. 11, 1954, p. 80, Est. 5, figs. 13 16; Mioceno Inferior, Cururu, Pará .

Material - 27 indivíduos coletados.

DESCRIÇÃo - Para a descrição da espécie referimos à supracitada publicação de Petri.

Dimensões - Espécimes figurados : 1) Diâmetros $0.37 \mathrm{~mm}$ e $0.31 \mathrm{~mm}$; espessura $0.22 \mathrm{~mm} .2$ ) Diâmetros $0.26 \mathrm{~mm}$ e $0.22 \mathrm{~mm}$; espessura $0.17 \mathrm{~mm}$.

Observações - Para comparações com espécies afins, referimos à supracitada publicação de Petri.

OCORRÊnCIAS - Urindeua (2), Fazenda (3), João Carlos (4), Pedrinha 6), Leôncio (7), Japerica (10), Tauari (15) e Canecos (21, 22a e o e $23 b$ e $c)$.

\section{Elphidium sp}

\section{Est. 4 Fig. 7}

Material -6 indivíduos coletados.

Descrição - Esta espécie se diferencia das outras do mesmo gênero, existentes na formação Pirabas, por ser bem deprimida, possuir a periferia lobada em tôda a extensão e umbílico largo e ornamentado.

Dimensões - Espécime figurado: Diâmetros $0.30 \mathrm{~mm}$ e $0.24 \mathrm{~mm}$; espessura $0.09 \mathrm{~mm}$.

ObSeRvações - Esta espécie se assemelha à $E$. paraensis Petri, do Mioceno de Cururu; distingue-se pela região umbilical mais estreita e pelas câmaras mais altas. É possível que com maior número de exemplares a identidade específica entre as 2 formas possa ser demonstrada. Por esta razão preferimos deixar esta forma com a "nomenclatura aperta"

A forma descrita por Petri (1952, p. 35 36) como Nonion sp. a, proveniente de Castelo (5), talvez seja idêntica à espécie em consideração. A ausência de processos retrais deve-se, possivelmente, ao estado de conservação do material.

Ocorrências - Urindeua (2), Castelo (5) e Canecos (21 e $22 a$ e $c$ ). 


\section{Archaias angulata (Fichtel e Moll) \\ Est. 2 Fig. 10}

Nautilus angulatus Fichtel e Moll, Test. Micr. 1803, p. 112. Est. 22, figs, a e e; Recente, Mediterrâneo e Mar da Arábia

Archaias angulatus (Fichtel e Moll), Cushman, U.S. Nat. Mus. Bull. 104, pt. 7, 1930, P. 16, Esst. 16, figs. 1-3; Est. 17, figs. 3 5; Recente, Atlântico, Pacífico e indieo.

Peneroplis sp. Petri. Fac. Fil. Ciên. e Letras, Univ. S. Paulo, Bol. Geol. 7, 1952, p. 33, Est. II, figs. 5 6; Est. III, fig. 7; Mioceno Inferior, formação Pirabas Castelo, Pará.

Archaias angulata (Fichtel e Moll), Petri, Fac. Fil. Ciên. e Letras, Univ. S. Paulo, Bol. Geol. 11, 1954, p. 83 85, Est. 6, figs. 5 7. 13 14; referências; Mioceno Infe-! rior, Cururu, Pará.

Material - 16 indivíduos coletados.

Descrição - Para a descrição da espécie referimos à publicação de Petri (1954, p. 83) sôbre os foraminíferos Iósseis de Marajó.

Dimensões - Espécime figurado: Diâmetros $0.85 \mathrm{~mm}$ e $0.70 \mathrm{~mm}$; espessura $0.30 \mathrm{~mm}$.

Observações - Os exemplares da formação Pirabas, como em geral acontece com outros foraminíferos, estão em estado de conservação inferior aos do Mioceno de Marajó. Esta espécie aparece na formação Pirabas ùnicamente sob a forma de molcles, estando fragmentada a maior parte do material. Um dos moldes encontrados possui a forma geral das testas desta espécie. Contudo os cordões formados pelo preenchimento das câmaras são nodosos, descontínuos, lembrando moldes de Taberina. Não obstante as partições se correspondem nids voltas sucessivas diferindo, portanto, dêsse último gênero, onde as partições são alternadas nas voltas sucessivas.

Pencroplis sp. proveniente de Castelo, deserita por Petri (1952, p. 33), talvez deva ser referida a esta espécie, embora a forma da testa e as câmaras aparentemente não divididas, sejam características do gênero Peneroplis. Este gênero não foi encontrado posteriormente na formação Pirabas. Talvez as câmaras secundárias não sejam visíveis, na forma referida no supracitado trabalho, devido ao mau estado de conservação.

Ocorrêsctas - Írindeua (1). Castelo (5). Tauari (15) e Salinópolis (19).

\section{Buliminella? sp.}

\section{Est. 4 Fig. 11}

Materiai - Sòmente um indivíduo coletado. 
Descriçĩo - Testa pequena, fusiforme; extremidacle inicial arredondada, aumentando ràpidamente de tamanho até aproximadamente o meio da testa, decrescendo então gradualmente para a extremidade apertural; face apertural larga e alta; periferia inteira, não lobulada; parede lisa, grosseiramente perfurada; abertura no meio da face apertural, dotada, ao que parece, de um dente largo.

Dinensões - Comprimento $0,26 \mathrm{~mm}$; largura $0.16 \mathrm{~mm}$.

Observaçós A testa é curta e entumecidla, com forma e tipo de enrolamento característicos do gềnero Buliminclla. Em virtude de possuirmos só um exemplar, não podlemos estar seguros se existe realmente un dente, ou a zona apertural está quebradla clando a aparência de dente. Por esta razão colocamos, duvidosamente, esta espécie no gênero Buliminella (Este gềnero não possui dente).

OCORRẾr'la - Salinópolis (19).

\section{Bolivina pirabensis Petri, sp. nov.}

\section{Est. 5 Figs. 1, 2}

Material - jindivíduos coletados.

Descrição - Testa pequena, alongada, com comprimento cêrca de duas vêzess a largura, alargando-se gradualmente de maneira que a maior largura fica situada na extremidade apertural; periferia inteira, não lobulada, excepto entre as cluas últimas câmaras, larga mas fazendo ângulo quase reto com a face lateral; câmaras com o comprimento aproximadamente igual i largura, aumentando gradativamente de comprimento a largura mas ràpidamente de espessura, de maneira que a testa é muito deprimida nos estágios inic iais, tornando-se mais bojuda nos estágios finais; as duas últimas câmaras são entumecidas; foram contadas cêrea de nove câmaras de cadla lado, fora a extremidade aboral onde elas não podem ser distinguidas; esta extremidade é aguda; suturas niveladas nos estágios iniciais, deprimidas entre as cluas últimas câmaras; a parede é rugosa e grosseiramente perfurada; a abertura consinte em uma estreita fenda alongada no sentido da face apertural.

Dinensós - Espécimes figurados: 1 ) Comprimento $0.22 \mathrm{~mm}$; largura $0.11 \mathrm{~mm}$; espessura $0.07 \mathrm{~mm}$. 2) Comprimento $0.23 \mathrm{~mm}$; largura $0.14 \mathrm{~mm}$; espessura $0.07 \mathrm{~mm}$.

Observaçóss - Esta pequena espécie, pelo seu alongamento e alargamento graduais, de maneira a se obter uma figura tendendo para cônica (2 últimas câmaras entumecidas, é muito caracteristica, não podendo ser comparada com nenhuma das espécies conhecidas de Bolivina.

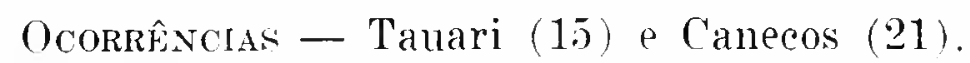




\section{Bolivina plicatella Cushman \\ Est. 5 Fig. 3}

Bolivina plicata Brady, Parker e Jones (Non d'Orbigny), Trans. Zool. Soc. London, vol. 12, 1888, p. 21; Recente, Banco dos Abrolhos, Brasil.

Bolivina plicatella Cushman, Flórida St. Geol. Surv. Bull. 4, 1930, p. 46, Est. 8, fiğs. 10a. b; Mioceno Inferior, formação Choctawhatchee, Flórida. - Petri. Fac. Fil. Ciên. e Letras, Univ. S. Paulo, Bol. Geol. 11, 1954, p. 90 91, Est. 4, figs. 22 25; referências; Mioceno Inferior, Cururu. Pará.

Material - 25 indivíduos coletados.

DEscRIÇÃo - A respeito da descrição e distribuições geográfica e gerológica da espécie, referimos à supracitada publicação de Petri.

Dimensões - Espécime figurado - Comprimento $0.26 \mathrm{~mm}$; largura $0.18 \mathrm{~mm}$; espessura $0.13 \mathrm{~mm}$.

Observações - Esta espécie aparece em um pacote restrito da secção miocênica de Cururu, Marajó, justamente na zona Bolivina plicatella. Cushman (Petri 1954, p. 43), quando rareiam os peneroplídios e Amphistegina lessonii d'Orbigny. Caso idêntico ocorre na formação Pirabas. A espécie Bolivina plicatella Cushman é característica do facies Canecos, não aparecendo no facies Castelo onde os peneroplídios e a espécie Amphistegina lessonii d'Orbigny são mais comuns. Isto sugere que a ocorrência restrita desta espécie de Bolivina em Cururu seja reflexo de modificações ecológicas o que aliás é sugerido pelo conjunto das associações características das zonas do Mioceno de Cururu. $23 d$ ).

Ocorrências - Japerica (10), Tauari (15) e Canecos $(21,22 c$ e

\section{Bolivina tortuosa Brady}

\section{Est. 5 Fig. 4}

Bolivina tortuosa, Brady, Quart. Journ. Micr. Soc. vol. 21, 1881, p. 57; Recente, Pacífico - Petri, Fac. Fil, Ciên. e Letras, Univ. S. Paulo, Bol. Geol. 11, 1954, p. 94. Est. 7, figs. 3, 4; referências; Mioceno Inferior, Cururu, Pará.

Material - 4 indivíduos coletados.

DescriçÃo - Testa curta e larga, muito deprimida, ligeiramente mais longa que larga, com periferia inteira, não lobulada, aguda e carenada; porção inicial da testa torcida e mais estreita que a porção adulta ; câmaras, cêrca de 4 de cada lado na porção adulta da testa, relativamente altas; suturas bem curvas, não deprimidas; parede com numerosas "punctae" grosseiras.

Dranensões - Espécime figurado: Comprimento $0.23 \mathrm{~mm}$; largura $0.16 \mathrm{~mm}$; espessura $0.06 \mathrm{~mm}$. 
Observações - Os espécimes da formação Pirabas concordam bem com a espécie de Brady. Cushman (1937 p. 134) salienta que a espécie. descrita originalmente do Pacífico, ocorre em sua forma típica, nas costas americanas, do Rio de Janeiro a Bermuda. A sua distribuição geológica é do Mioceno a Recente. Os espécimes de Pirabas, como aliás os de outras regiões do Mioceno (Cushman Idem, p. 135), possuem o estágio in:-ial, antes de se alargar para a porção adulta, mais longo que os espécimes post-miocênicos. Cushman (Idem, p. 134) em sua descrição da espécie ^n consideração, afirma que a periferia é aguda mas não carenada; entretanto, nas stuas ilustrações (Idem, Est. 17, figs. 11 19) nota-se uma carena bem distinta.

Esta espécie foi por nós referida, com dúvida, no Mioceno de Marajó (Petri 1954, p. 94). Os exemplares de Marajó são mais alongados, afastando-se da forma típica da espécie.

OcorrêActa - Tauari (15).

\section{Bolivirea sp.}

\section{Eet. 5 Figs. 5, 6}

Material -3 indivícluos coletados.

Descriçĩo - Testa alongada, deprimida ; periferia carenada ; câmaras distintas. largas e baixas, ligeiramente infladas; cêrea de 7 câmaras visíveis de cada lado, sendo que a porção inicial é indistinta; suturas distintas, deprimidas, encontrando a periferia em ângulo agudo; parede finamente perfurada ; vista periferal em forma de elipse alongada.

Dimensões - Espécimes figurados: 1) (omprimento $0.32 \mathrm{~mm}$; largura $0.14 \mathrm{~mm}$; espessura 0.0.5 mm. 2) Comprimento $0.26 \mathrm{~mm}$; largura $0.12 \mathrm{~mm}$; espessura $0.07 \mathrm{~mm}$.

Observações - Os nossos pṣpécimes lembram! $B$. alate (Seguenza) no tamanho, proporȩão tla testa e forma e disposição das câmaras, havendo como naquela espécie, ligeira expansão alar das câmaras. Contudo os septos não são curvos como em $B$. alata (Seguenza) e encontram-se em ângulo mais agudo na região axial; a expansão alar é também menos desenvolvida.

A rista periferal do espécime representado na Est. 5 fig. 5 , difere da rista periferal dos outros espícimes pela carena bem distinta que chega até a abertura e pelo eixo da testa deprimido.

$$
\text { OCorrências -- Japerica (10) e Canecos }(21 \text { e } 23 \text { d). }
$$




\section{Angulogerina hughesi (Galloway e Wissler) Est. 5 Fig. 7}

Livigerina hughesi (ialloway e Wissler, Journ. Pal. vol. 1, 1927, p. 76, Est. 12, fig. 4; Plioceno, Tims Point e Pleistoceno, Lomita, Califórnia

Angulogerina hughesi (Galloway e Wissler), Cushman, Stewart e Stewart, Trans. Siln Diego Soe. Nat. Hist. vol. 6, 1930, p. 70, Es t. 5, fig. 16, Pleistoceno, Califórnia Cushman e Todid, Contr. Cush. Lab. Foram. Res. vol. 17. pt. 3, 1941, p. 76, Est. 18, fig. 4; Est. 19. fig. 17; Pleistoceno, Califórnia.

Angulogerina cf. rugoplicata Petri (Non Cushman), Fac. Fil. Ciên. e Letras, Univ. S. Paulo, Bol. Geol. 11, 1954, p. 98 99, Est. 7. figs. 18 19; Mioceno Inferior, Cururu, Pará

Material - 21 inaiivíluos coletados.

DEscriçĩo - Testa alongada, com o comprimento aproximadamente duas vêzes e meia a largura, triangular em vista apertural ; câmaras adultas com faces ligeiramente côncavas e angulares, truncadas na periferia; as câmaras iniciais tendem a se tornar uniformemente entumecidas; suturas da porção adulta fortemente deprimidas, as iniciais um tanto indistintas; parede distintamente perfurada, com ligeiros traços de estrias longitudinais na porção inicial, o restante la testa com parede lisa, sem ornamentação; abertura circular, terminal, com um peseoço cilíndrico muito 'urto e um pequeno lábio arredondado.

Dinensões - Espécime figurado: Comprimento $0.27 \mathrm{~mm}$; largura $0.13 \mathrm{~mm}$; espessura $0.10 \mathrm{~mm}$.

OBservações - Petri (1954, p. 99) ressaltou que os espécimes de Cururu diferiam de $A$. hughesi (Galloway e Wissler), por possuirem as (âmalas mais escavadas; conturlo as diferenças entre a forma de Cururu * A. rugoplicata Cushman, como foram apontadas por Petri (Idem, idem), parecem ser de grau mais elevado. Os exemplares de Pirabas se aproximam ainda mais de $A$. hughesi (Galloway e Wissler) por mostrarem as câmaras menos escavarlas que nos exemplares de Cururu.

A espécie $A$. colombiana Rectmond, do Mioceno Médio da Colômbia talvez seja coespecifica com a espécie em consideração. As diferenças apontadas por Redmond (1953, p. 723 ) entre A. hughesi (Galloway e Wissler) e a forma colombiana são ligeiras e apenas de natureza quantitativa.

()corrêxcias - Fazenda (3) e Canecos (21 e 22 a, r).

\section{Angulogerina parcensis Petri, sp. nov. \\ Est. 5 Figs. 8, 9}

Angulogerina ef. jamaicensis Petri (Non Cushman e Todd). Fac. Fil. Ciên. e Letras, Univ. S. Paulo, Bol. Geol. 11. 1954, p. 97 98. Est. 7, figs. 14 17; Mioceno Inferior, Cururu. Pará. 
Material - 22 indivíduos coletados.

Descrição - A respeito da descrição da espécie, referimos à supracitada publicação de Petri.

Dimensões - Espécimes figurados: 1) Comprimento $0.29 \mathrm{~mm}$; largura $0.15 \mathrm{~mm}$. 2) Comprimento $0.20 \mathrm{~mm}$; largura $0.12 \mathrm{~mm}$.

OBservações - Verificamos que as diferenças apontadas entre os espécimes de Marajó e os pertencentes a A. jamaiconsis Cushman e Todd também subsistem para os espécimes da formacão Pirabas, justificando, portanto, a separação dêsses espécimes em uma espécie distinta. ' A espécie brasileira é mais alongada, com projeções das câmaras para fora menos acentuadas e com a vista apertural mais arredondada. Por êste último caráter ela pode ser considerada como intermoliária entre os gêneros Angulogerina e Uevigerina.

$$
\text { OCorrênctas - Pedriuha (6), .Japerica (10) e Tamari (15). }
$$

\section{Spirillina ct. vivipara Ehrenberg}

\section{Est. 5 Fig. 10}

Spirillina vivipara Ehrenberg, Abhandl K. Akad. Wiss. Berlim, 1841. p. 422, Est. 3, sec. 7, fig. 41; Recente, Gôlfo do México-Cushman, U.S. Nat. Mus. Bull. 104, pt. 8, 1931, p. 3-4, Est. 1, figs. 1 4; referências; Recente, Cárabas. - Galloway e Heminway, New York Acad, Sci., rol. 3, pt. 4, 1941; p. 299. Est. 1, $3 a, . b$; Oligoceno Superior Mioceno Inferior formaçóes Cibao e Ponce, Pôrto Rico. - Cushman e Gray, Cush. Lab. Foram. Res., Sp. Publ. 19, 1946, p. 37, Est. 6, fig. 20; Plioceno, Tims Point, Califórnia. - Said Cush. Lab. Foram Res., Sp. Publ. 26, 1949, p. 34-3.5, Est. 3, fig. 31; Recente, Mar Vermelho. - Bermudez, Mem. Soe. Culana Hist. Nat. vol. XIX, 11. 3, 1950, p. 362; Mioceno Médio, Recente; Cuba.

Material - 20 indivíduos coletados.

Descrição - A espécie é pequena, bem deprimicla; a testa é planospiral evoluta; ela possui cêrea de + voltas do corpo, estreitas e com diâmetro uniforme; a parede mostra, como ornamentação, apenas grosseiras depressões alinhadas, próximas às suturas espirais; em raros indivíduos, a testa não é planospiral mas ligeiramente trocoide em forma de um cone bem deprimido.

Drmensões - Espécime figurado: I)iâmetros $0.23 \mathrm{~mm}$ e $0.22 \mathrm{~mm}$; espessura $0.04 \mathrm{~mm}$.

OBservações - Seguimos aqui o critério adotado por Cushman e outros que atribuem, com dúvida, à espécie vivipara, tôdas as formas evolutas, deprimidas, planospirais. com periferia arredondada e suturas um tanto deprimidas e tendo como ormamentação apenas grosseiras depressioes mais ou menos alinhadas.

Ocokrêxora - Trindena (2), Japerica (10) e Salinópolis (19). 


\section{Discopulvinulina pirabensis Petri, sp. nov. Est. 6 Fig. 1}

Material - 30 indivíduos coletados.

Descriçĩo - Testa ligeiramente alongada, deprimida; lado dorsal convexo, lado ventral côncavo; seis a oito câmaras na última volta do corpo, aumentando ràpidamente de tamanho e dotadas de projeções para o umbílico; cêrca de duas voltas e meia visíveis do lado dorsal; suturas limbadas e niveladas no lado dorsal, cleprimidas no lado ventral; periferia ligeiramente lobulada, angular; parede finamente perfurada em ambos os lados; a abertura é constituíla por uma fenda alongada na base da última câmara, abrindo-se para o umbílico.

Dimensões - Espécime figuraclo; Diâmetros $0.46 \mathrm{~mm}$ e $0.36 \mathrm{~mm}$; espessura $0.12 \mathrm{~mm}$.

Observações - Esta espécie é afim a D. floridensis (Cushman) diferindo pelo número de câmaras por volta do corpo (8 em $D$. pirabensis; 4 a 5 em $D$. floridensis aumentando de tamanho em rítmo mais acelerado).

OCorrências - Urindeua (2), Castelo (5), .Taperica (10), Tauari (15), Salinópolis (19) e Canecos $(21,22 a, c)$.

\section{Discorbis paraensis Petri, sp. nov. \\ Est. 5 Figs. 11, 13}

Material - 404 indivíduos coletarlos.

Descrição - Testa calcária, perfurada, trocoide, cônica; lado dorsal evoluto, convexo, elevado; lado ventral involuto, plano ou ligeiramente côncavo; as câmaras são em número de 4 na última volta do corpo nas testas jovens, aumentando para 5 a 6 nas adultas; elas aumentam bruscamente de tamanho; periferia ligeiramente lobulada, arredondada nas testas jovens, passando para angular nas adultas; é bem visível, em nossos espécimes, a presença de reentrâncias suturais no lado ventral, uma para cada sutura, entre o umbílico e a periferia, mais proximas daquele; a abertura é constituída por uma fenda na base da face apertural.

Dimensões - Espécimes figurados: 1) Diâmetros $0.30 \mathrm{~mm}$ e $0.26 \mathrm{~mm}$; espessura $0.15 \mathrm{~mm}$. 2) Diâmetros $0.29 \mathrm{~mm}$ e $0.24 \mathrm{~mm}$; espessura $0.11 \mathrm{~mm}$. 3) Diâmetros $0.18 \mathrm{~mm}$ e $0.17 \mathrm{~mm}$; espessura $0.10 \mathrm{~mm}$.

Observações - 1 presença de reentrâneias suturais foi notada por Bermudez (1952, p. 33, Est. III, fig. 1) em rliversas espécies como por exemplo Discorbis advena Cushman; esta particularidade foi considerada por Bermudez como característica do gênero Discopulvinulina Hofker. 
O gênero Discopulvinulina tem como genótipo "Rosalina bertheloti d'Orbigny", espécie esta bem distinta do grupo de Discribis advena Cushman. Hornbrook e Vella (1954, p. 26 28) mostraram que reentrâncias suturais ("sutural clefts") bem como um complexo de placas umbilicais são características do gênero Discorbis sensu strictu; as placas umbilicais não são visíveis, contudo, nos nossos indivíduos; elas talvez sejam originadas, em outras espécies, pela coalescência das reentrâncias suturais.

A nosśa espécie, pelo forte desenvolvimento das reentrâncias suturais, se alia a $D$. advena Cushman, $D$. mauricensis Howe e Roberts e $D$. javana Le Roy. Ela se distingue das duas primeiras espécies por ser menos deprimida, pela periferia menos lobulada e carenada e pelas câmaras mais altas; a outra espécie $D$. javana Le Roy é muito característica por ser bem cônica.

OCORRÊncias - Salinópolis (19) e Canecos (21, 22 a, r e 23 b e d ).

\section{Discorbis ? sp}

\section{Est. 5 Fig. 14}

Material - 13 indivíduos coletados.

Descrição - Testa deprimida; lado dorsal convexo, lado ventral côncavo; periferia aguda, inteira, carenada; todas as voltas do corpo, cêrca de duas, visíveis do lado dorsal, sòmente a última volta visível do lado ventral; cinco a seis câmaras, aumentando ràpidamente de tamanho, formam uma volta do corpo; suturas distintas, limbadas tanto no lado dorsal como ventral, um tanto salientes e curvas; parede lisa, grosseiramente perfurada; a abertura não está clara no nosso material.

Dimensões - Espécime figurado: Diâmetros $0.26 \mathrm{~mm}$ e $0.22 \mathrm{~mm}$; eз̉pessura $0.07 \mathrm{~mm}$.

ObSERVAÇões - Esta espécie pelo carater limbado das suturas lembra Discorbis subaraucana Cushman, principalmente a variedade dissona Cushman e Ellisor, diferindo por ser mais deprimida e pela periferia aguda, carenada. Ela lembra também a espécie descrita como $D$. berthelot $i$ (d'Orbigny) var complanata Sidebotton, forma recente das costas da Australia. Distingue-se por ser, o lado ventral, completamente involuto.

A incerteza quanto a natureza da abertura, bem como o estado de conservação dos espécimes examinados, fizeram com que não fosse possível chegar a um diagnóstico genérico preciso.

$$
\text { OCORRÊnCIAS - Canecos (22 } a \text { e } 23 b, d) \text {. }
$$




\section{Conorbella americana Petri, sp. nov. Est. 6 Fig. 2}

Discorbis cf pu:elliformis Bermudez (Non Brady), Cush. Lab. Foram. Res., Sp. Publ. ㄱ.5. 1949, p. 240, Est. 15, figs. 34-36; Mioceno Médio, formināo Gurabo, S. Domingos.

Discorbis oatelliformis Petri (Non Brady), Fac. Fil. Ciên. e Letras, Univ. S. Paulo, Bol. Ceol. 11. 1954, p. 101, Est. 8, figs. 5 7; Mioceno Inferior, Cururu, Pará.

Material - 81 indivíduos coletados.

Descrióño - Testa calcária, perfurada, cônica; lado dorsal formando mi cone elevado, lado ventral aproximadamente plano; umbílico no lado ventral coberto por um nódulo umbonal; lado ventral coberto por estrias rarliais as quais só estão claras nos espécimes melhor conservados; periferia aguda; a abertura é constituída por uma fenda na base da face apertural, uo lado ventral.

Dimensões - Espécime figurado: Diâmetro $0.27 \mathrm{~mm}$; altura $0.17 \mathrm{~mm}$.

()Bservações - A nossa espécie é intimamente relacionada a "Discorbiru patelliformis Brady" tendo mesmo sido descrita, no Mioceno de Marajó, como sendo idêntica à espécie de Brady. Ela se distingue, contudo, lesta última, por apresentar, na região umbilical, um nódulo em lugar de uma série de grâmulos. Hâ tendência também para as testas serem mais cônicas. O exemplar aqui figurado representa a moda, havendo espécimes tão cônicos quanto o figurado por Bermudez (1949, Est. 15, figs. 3436) "omo Discarbis of patelliformis (Brady), proveniente do Mioceno de S. Domingos e que talvez seja idêntico à nossa espécie. A espécie "Discorbina patelliformis Brady" é proveniente do Pacífico, não tendo sido encontrada, com certeza, no oceano Atlântico. As vêzes, em nossos espécimes, o tampão umbilical se destaca deixando em seu lugar uma depressão.

A espécie "Discorbina patelliformis Brady", foi colocada por Bermulez (1952, p. 37) no gênero Conorbella Hofker, eujo genótipo é "Discorbina pulcinate! Brady" Segundo Hornbrook e Vella (1954, p. 25), ("onorbella e sinónimo de Glabrutella Dorreen, gênero êste que tem como genótipo G. crassa Dorreen. Tanto "Discorbina pulvinata Brady" como Glabratella crassa Dorreen são espécies globosas contrastando com a forma histintamente plano-convexa e com periferia inteira e aguda que caracteriza o grupo de espécies aliadas a "Discorbina patelliformis Brady" Contudo Hofker (1954, p. 34) salienta que o gênero Conorbclla compreende año só formas com periferia arredondada como também formas com periferia angular. Mantemos aqui o ponto de vista de Hofker colocando nêste gênero a presente espécie.

OCoRrêscias - T'indeua (2), João Carlos (4), Leôneio (7). Japerica (10), Tauari (15), Salinópolis (19) e Canecos (23b e $d)$. 


\section{Neoconorbina terquemi (Rzehak)}

\section{Est. 6 Fig. 3}

Rosalina orbicularis Terquem (Non d'Orbigny), Essai Class. Anim. Dunkerque, pt. 2, 1876, p. 75. Est. 9, fig. 4; Recente, França.

Discorbina terquemi Rzehak (nom. nov.), Geol. Reichsanst. Verh. Austria, n. 11, 1888, p. 228.

Discorbis orbicularis (Terquem), Cushman, U.S. Nat. Mus. Bull. 104, pt. 8, 1931, p. 27, Est. 6. fig. 3; Recente, Atlântico. - Petri, Fal. Fil. Ciên. e Letras, Univ. S. Paulo, Bol. Geol. 11, 1954, p. 100 101, Est. 8, figs. 2 4; referências; Mioceno Inferior, Cururu Pará.

Discorbis terquemi (Rzehak), Redmond, Journ. Pal. vol. 27, n. ${ }^{\circ}$ 5, 1953 p. 724. Est. 76, figs. 2 a c; Mioceno Médio, formação Tubara, Zona I, Colômbia.

Neoconorbina terquemi (Rzehak), Hofker, Arch. Néerl. Zool. Leiden, vol. 8, pt. 4, 1951, p. 357.

Material - 11 indivíduos coletados.

DEsCrIÇÃo - Para a deserição da espécie referimos à supracitada publicação de Petri.

Dimensões - Espécime figurado - Diâmetros $0.28 \mathrm{~mm}$ e $0.27 \mathrm{~mm}$; altura $0.10 \mathrm{~mm}$.

ObSERVAÇões - Esta espécie foi descrita originalmente como Rosalina crbicularis Terquem. Ela foi tomada como genoholótipo do gênero de Hofker, Neoconorbina, que Bermudez (1952, p. 34) considera como sinônimo de Resaiina mas que Hornbrook e Vella (1954, p. 26) cons:deram como gênero válido. Os caracteres críticos dn gênero Neoconorbina apontados por Hofker como a testa cônica e a vista ventral mostrando dois foramens separados por um lábio, são visíveis nos espécimes de Pirabas. Hofker (Em Ellis e Messina sob Neoconorbina marginata. Hofker 1951) \& da opinjão qu. diversas espécies foram descritas como "Discorbis orbicularis (Terquem) = Rosalina orbicularis Terquem": Tma ocorrendo nas costas da Inglaterra para a qual deve ser conservarlo o nome $N$ terquemi (Rzehak); outra espécie no Mediterrâneo, outra no Oceano Pacifíco e finalmente uutra na região das Caraibas. Os nosses espécimes mostram poros espalhaclos na parede da testa, mais distintamente no lado dorsal, enquanto o rentral tem aspecto polido. A sutura no lado dorsal é distinta; a abertura no lado ventral, próximo ao umbílico, mostra um lábio bem distinto. Esses caracteres, parecem apontar para a espécie das Caraibas, a qual não foi denominada, especificamente por Hofker.

OCORRÊnctas - Salinópolis (19). Alguns indivíduos provenientes de Urindeua (2), Japerica (10). Tauari (15) e Canecos (23b) talvez possam ser colocados aqui, contudo, o estado de conservação dos mesmos não permite uma diagnose segura. 


\section{Eponides repandus (Brady) \\ Est. 6 Fig. 4}

Pulvinulina repanda Brady (Non Nautilus repandus Fichtel e Moll) Rep. Voy. Challenger, Zool. vol. 9. 1884, p. 684, Est. 104, figs. 18a, c; Recente

Eponides repanda (Fichtel e Moll), Cushman, U.S. Nat. Mus., Proc. vol. 75, art. 25, 1929, p. 11,, Est. 4, fig's. 7a, i; Recente.

Eponides repandus (Fichtel e Moll) - Cushman e Ponton, Flórida St. Geol. Surv. Bull. 9, 1932. p. 92. Est, 13, figs. 9a, c; Mioceno Inferior, Flórida. - Petri, Fac. Fil. Ciên. e Letras, Univ. S. Paulo, Bol. Geol. 11, 1954, p. 105 106, Est. 9, figs. 7 9; referências; Mioceno Inferior Cururu, Pará.

Material - 20 indívíduos coletados.

Descrição - Para a descricãa e distribuições geográfica e geológica da espécie, referimos à supracitada publicação de Petri.

Dimensões - Espécime figurado - Diâmetros $0.58 \mathrm{~mm}$ e $0.49 \mathrm{~mm}$; espessura $0.32 \mathrm{~mm}$.

Observações - Eponides repancius tem sido muito citado na literatura. Parece que diversas espécies estão incluidas sob essa denominação. Redmond (1949, p. 19-21) chamou a atenção para a confusão a respeito desta espécic que também é o genótipo de Eponidcs, criado por Montfort em 1808, baseado em Nautilus repandus Fichtel e Moll. O uso, contudo, consagrou o têrmo Eponides para formas semelhates ou, idênticas à Pulvinulina repanda Brady. Esta espécie se diferencia elaramente de Nau. tilus repandus Fichtel e Moll.

Ocorrências - Urindeua (2), Castelo (5), Pedrinha (6) e Salinópolis (19).

\section{Eponides? sp.}

\section{Est. 6 Fig. 5}

Material - Sòmente um indivíduo coletado.

Descriçño - Testa oval-alongada, lado dorsal plano, lado ventral convexo; periferia aguda, carenada; câmaras aumentando ma is em altura que em largura, um tanto infladas no lado ventral, principalmente as últimas ; suturas dorsais com sugestões de ornamentação em contas, não sendo contudo claras; suturas ventrais um tanto deprimidas, principalmente a última; sete câmaras formam uma volta do corpo; parede grosseiramente perfurada; a abertura não está clara no nosso material.

Dimensões - Diâmetros $0.58 \mathrm{~mm}$ e $0.43 \mathrm{~mm}$; espessura $0.29 \mathrm{~mm}$.

Observações - 0 estado de conservação do espécime aqui considerado não está bom, razão porque a afiliação genérica é duvidosa. A abertura não está clara, e a testa em geral é do tipo de Eponides se bem que a forma 
um tanto lobulada das câmaras e a presença de projeções umbilicais destas fazem lembrar o gênero Valvulineria.

\author{
OCORRÊNCIA - Urindeua (2).
}

\title{
Streblus beccarii (Linné) var. mendesi Petri
}

\section{Est. 7 Figs. 1, 2}

Rotalia beccarii (Linné) var, parkinsoniana Cushman (Non Rosalina parkinsoniana d'Orbigny) - Flórida St. Geol. Surv. Bull. 4, 1930, p. 56, Est. 11, figs. 3a, c; Mioceno, Flórida. - Cushman e Cole, Contr. Cush. Lab. Foram. Res. vol. 6. pt. 4, 1930, p. 100, Est. 13, figs. 14 a c; Pleistoceno, Maryland - Cushman e Ponton, Flórida St. Geol. Surv. Bull. 9, 1932, p. 93: Mioceno, Flórida - Cushman e Cahill, U.S. Geol. Surv. Prof. Paper 175-A, 1933, p. 31. Est. 11, figs. 3a c; Minceno; Flórida, Carolina do Sul e do Norte.

"Rotalia" beccarii (Linné) var. angulata Petri - Fac. Fil. Ciên. e Letras. Univ. S. Paulo, Bol. Geol. 11, 1954, p. 105 108, Est. 9, figs. 10 12; Mioceno Inferior, Cururu; Pará.

"Rotalia" sp. - Petri, Fac. Fil. Ciên. e Letras, Univ. S. Paulo, Bol. Geol. 7. 1952 p. 34, Est. III, figs. 5 6; Mioceno Inferior, formação Pirabas, Castelo, Pará.

Eponides sp. - Petri, Fac. Fil. Liên. e Letras, Univ. S. Paulo, Bol. Geol. 7, 1952, p. 35, Est. III, figg. 3 4; Mioceno Inferior, formação Pirabas, Castelo, Pará.

Streblus bassleri - Petri (Non Cushman e Cahill), Fac. Fil. Ciên. e Letras, Unir. S. Paulo, Bol. Geol. 11, 1954, p. 107 108; Mioceno Inferior, Cururu, Pará

Material - 193 indivíduos coletados.

Descrição - Testa aproximadamente circular, trocoide; lado dorsal convexo deprimido a bem abaulado, lado ventral plano a convexo deprimido; periferia angular e não lobulada; cêrea de 3 voltas do corpo viáveis do lado dorsal; sete a nove câmaras na última volta do corpo, aumentando gradativamente de tamanho; suturas dorsais niveladas com o resto da testa, ligeiramente limbadas; suturas ventrais escavadas largas, e limbadas, alargando-se para a região umbilical; a rolha é grande e perfeitamente separada das câmaras; parede finamente perfurada ; abertura mediana, na base da face apertural.

Dimensões - Espécimes figurados - 1) Diâmetros $0.35 \mathrm{~mm}$ e $0.32 \mathrm{~mm}$; espessura $0.14 \mathrm{~mm} .2$ ) Diâmetros $0.33 \mathrm{~mm}$ e $0.30 \mathrm{~mm}$; espessura $0.16 \mathrm{~mm}$.

ObSERVAÇóes - Esta variedade foi reconhecida pela primeira vez no Mioceno de Marajó com o nome de "Rotalia" beccarii (Linné) var. angulata Petri (*) (Petri 1954, p. 106 108); como já foi dito no supracitado

(*) O Dr. Hans R. Thalmann, em rarta de 22 de Novembro de 1954, teve a gentileza de chamar a atençāo para a denominạ̃ão da espécie "Rotalia" béccurii (Linné) var. angulata Petri, a qual está preocupada por Rotalia ketienziensis (Ishizaki) var. angulata Kuvano. Em vista disso, propuz em carta endereçada no Dr. Thalmann, datada de 21 de Dezembro de 1954 , a mudança do nome angulata para mendesi, em homenagem ao paleon tólogo brasileiro Dr. Josué Camargo Mendes. 
trabalho de Petri, ela parece ser idêntica a descrita por Cushman e Cahill (1933, p. 31) com o nome de Rotalia beccarii (Linné) var. parkinso. niana (d'Orbigny) e proveniente do Mioceno de Flórida e Carolina do Su!. Contudo ela não é idêntica à forma descrita por d'Orbigny como Rosalina parkinsoniana a qual, segundo Bermudez (1952, p. 73), não aparece nas Antilhas e sim no norte da Europa.

Na Estampa 7, figs. 3 4, estão reproduzidos dois espécimes provenientes do Mioceno de Marajó para comparações com os espécimes de Pirahas.

OCorrîncias - Fazenda (3), Tauari (15) Marapanim (17), Salinónclis (19) e Canecos $(21,22 a, c$ e 23 b).

\section{Streblus catesbyanus (d'Orbigny) var. tepida (Cushman) Est. 7 Figs. 5, 6}

Ro:alia beccarii (Linné) var. tepida Cushman, Publ. 344, Carnegie Inst. Washington, 1926, p. 79, Est. 1; Recente, Pôrto Rico. - Cushman, U.S. Nat. Mus. Bull. 104, pt. 8, 1931, p. 61, Est. 13, figs. 3a c; Recente, Caraibas. - Palmer, Bull. Am. Pal. vol. 29, n. 115, 1945, p. 60; Mioceno Médio, formação Bowden. Jamaica. - Bermudez, Mem. Soc. Cubana Hist. Nat., vol XIX, n. 3, 1950, p. 359; Plioceno - Recente, Cuba. Phleger e Parker, Geol. Soc. Am. Mem. 46, pt. II, 1951, p. 23, Est. 12, figs. $7 a b$; Recente, Golfo do México

Streblus beccarii (Linné) var. tepida (Cushman) Bermudez, Cush. Lab. Foram. Res. Sp. Publ. 25, 1949, p. 234, Est. 15, figs. 49 51; Mioceno Superior, formação Las Salinas, São Domingos.

Streblus cate byanus (d'Orbigny) var. tepida (Cushman), Bermudez, Min. Minas e Hidrocarburos, Venezuela, vol. II, n. 4, 1952 p. 74; Plioceno - Recente, Venezuela.

Material - 275 indivíduos coletados.

Descrição - Testa bi-convexa deprimida, com 6 a 7 câmaras na última volta do corpo; cêrca de 2 voltas e meia visíveis do lado dorsal; periferia arredondada; suturas dorsais ligeiramente deprimidas, simples, não limbadas, a não ser ligeiramente na base; suturas ventrais muito deprimidas, radiais; as câmaras se separam em direção ao umbílico, formando espaços abertos, angulares; sem rolha; parede lisa, finamente perfurada; a abertura consiste em uma fenda estreita próxima ao umbílico e em uma fenda na base da face apertural, na zona mediana.

Dimensões - Espécimes figurados : 1) Diâmetros $0.38 \mathrm{~mm}$ e $0.32 \mathrm{~mm}$; espessura $0.17 \mathrm{~mm} .2$ ) Diâmetros $0.30 \mathrm{~mm}$ e $0.24 \mathrm{~mm}$; espessura $0.14 \mathrm{~mm}$

Orservações - Este fóssil é indice de ambiente de águas bem rasas tendendo para salohra. $\mathbf{E}$ característico do fácies Caneccs.

OCorrências - Japerica (10), Baunilha Grande (11), Tauari (15) e Canecos (21, 22a, c e 23b, c d). 


\section{Siphonina pulchra Cushman \\ Est. 6 Fig. 6}

Siphonina pulchra Cushman, Carnegie Inst. Washington, Publ. 291, 1919, p. 42, Est. 14, fig. 17. - Petri, Fac. Fil. Ciên. e Letras, Univ. S. Paulo, Bol. Geol. 11, 1954, p. 108 109, Est. 10, figs. 1 3; referências; Mioceno Inferior, Cururu, Pará

Material -8 indivíduos coletados.

DESCRIÇão - Testa pequena, igualmente biconvexa, mais entumecida no meio e decrescendo gradativamente para a perifer. a que é aguda e ligeiramente lobulada; uma pequena carena tubulosa existe bordejando a testa; cineo câmaras formàm 1 volta do corpo; as câmarass só são bam distintas na última volta; elas são, vistas do lado dorsal, altas e estreitas, vistas do lado ventral, aproximadamente triangulares; suturas niveladas no lado dorsal, ligeiramente deprimidas e radiais no lado ventral.

Dimensões - Espécime figurado: Diâmetros $0.22 \mathrm{~mm}$ e $0.20 \mathrm{~mm}$; espessura $0.09 \mathrm{~mm}$.

ObServações - Os espécimes da formação Pirabas são mais largos e deprimidos do que os do Miceeno de Marajó.

OCORRÊnCIaS - Paracarema (9), Japerica (10) e Canecos (23b).

\section{Pseudobulimina? sp. \\ Est. 6 Fig. 7}

Material - Sòmente um indivíduo coletado.

Descrição - Testa tendendo para evoluta, alongada, deprimida ; lado ventral ligeiramente côncavo, lado dorsal convexo; periferia aguda, carenada; seis câmaras visíveis na última volta do corpo; elas aumentam gradativamente de comprimento mas bruscamente de largura, principalmente no lado dorsal, onde se estendem bem para os lados; a última câmara forma uma face larga no lado rentral, ocupando quase a metade da testa; suturas deprimidas. tendendo para radiais, no lado ventral, curvas e limbadas no lado dorsal, onde devido as suas posições, as câmaras tendem a se dispôr unisserialmente; umbílico inexistente; parede grosseira e distintamente perfurada em ambos os lados, mas mais distintamente no lado ventral; uma fenda alongada e perpendicular a sutura, partindo do meio da base da face apertural no lado ventral e dirigincio-se para a periferia, ocupa mais de três quartos do comprimento da face apertural.

Dimensões - Diâmetros $0.23 \mathrm{~mm}$ e $0.15 \mathrm{~mm}$; espessura $0.07 \mathrm{~mm}$.

ObServaçōes - Esta espécie se filia à famíliı Ceratobuliminidae, sub-família Ceratobulimininae no conceito de Bermudez (1952, p. 79), pela testa trocoide e pelo tipo de abertura; ela, contudo, 
não se coloca em nenhum dos gêneros conhecidos desta subfamília. Nós a referimos, com dúvidas, ao gênero Pseudobulimina por possuir, como nêste gênero, a testa pràticamente plano convexa alongada, com tendência a desenrolamento, suturas limbadas e face apertural larga e achatada, ocupando quase a metade da testa e dotada de uma fenda na região mediana dirigida no sentido distal; contudo, diferencia-se dêste gênero por possuir a periferia aguda, carenada e pela ausência de câmaras secundárias no lado dorsal. O lado ventral mostra algumas formações que talvez possam ser interpretadas como câmaras secundárias, contudo não se pode ter certeza sôbre a verdadeira natureza destas formações, devido ao estado de conservação, mormente quando só possuimos um indivídıo para exame.

OCORRÊnCIA - Canecos (21).

\section{Operculina? sp.}

\section{Est. 5 Fig. 15}

Material - 5 indivíduos coletados.

Descrição - Testa relativamente pequena, circular, evoluta, bem deprimida; suturas grossas, limbadas, não se destacando por ornamentação de espécie alguma; câmaras em número de 12 a 13 na última volta do corpo, curtas e largas, aumentando gradualmente de tamanho.

Dimensões - Espécime figurado: Diâmetros $1.10 \mathrm{~mm}$ e $0.96 \mathrm{~mm}$; espessura $0.17 \mathrm{~mm}$.

Observações - É estranho a presença dêsse gênero em uma fauna do Mioceno Inferior, visto que a maioria da família nummulitidae foi extinta, na província caraíbica, no Oligoceno. Esses fósseis poderiam ter sido redepositados e proviriam de formações mais antigas. Estas considerações levantam a possibilidade de existência, na região, de formações mais antigas que o Mioceno, de maneira idêntica a que acontece na região dé Cururu. É mais provável, contudo, que êles representem rema. nescentes do gênero que teriam persistido no Mioceno de Pirabas.

OCORRência - Salinópolis (19).

\section{Amphistegina lessonii d'Orbigny \\ Est. 8 Figs. 1 - 3}

Amphistegina lessonii d'Orbigny, Ann. Sci. Nat. vol. 7, 1826. p. 304, Est. 17. figs. 14 (A. quơii na descrição das estampas). Recente, França. - Petri, Fac. Fil. Ciên. e Letras. Univ. S. Paulo, Bol. Geol. 11, 1954, p. 110 115, Est. 10, figs. 10 16; Est. 11, figs. 1 6; referências; Mioceno Inferior, Cururu, Pará.

MATERIAL - 186 indivíduos coletados.

Descriçĩo - Para a descrição e distribuições geográfic‘a e çeológica, leferimos à publiceação de Petri supracitada. 
Dimensões - Espécimes figurados : 1) Diâmetros $1,39 \mathrm{~mm}$ e $1.25 \mathrm{~mm}$; espessura $0.50 \mathrm{~mm}$; 2) Variedade conica: Diâmetros $0.35 \mathrm{~mm}$ e $0.30 \mathrm{~mm}$; espessura $0.14 \mathrm{~mm}$. Variedade tumida: Diâmetros $1.13 \mathrm{~mm}$ e $0.96 \mathrm{~mm}$; espessura $0.58 \mathrm{~mm}$.

Observações - Esta espécie é, na formação Pirabas, tão variável como no Mioceno de Cururu. Da mesma maneira como em Cururu, (Petri 1954, p. 110 115) podem-se distinguir na formação Pirabas, além da forma típica lenticular, as variedades bojudas tumida e conica. Encontramos também aqui formas erodidas, mostrando a granulação da parede das câmaras anteriores próxima às antigas aberturas.

Ocorrências - Urindeua (1 e 2), Fazenda (3), João Carlos (4), Castelo (5), Pedrinha (6), Tauari (15), Marapanim (17), Salinópolis (19) e Canecos (23 b, $c$ e $d)$.

\section{Cassidulina laevigata d'Orbigny Est. 6 Fig. 8}

Cassidulina laevigata d'Orbigny, Ann, Sci. Nat. vol. 7, 1826, p. 282, Est. 15, figs. 4 5; Modèles n. 41, Recente. - Petri, Fac. Fil. Ciên. e Letras, Univ. S. Paulo, Bol. Geol. 11, 1954, p. 116, Est. 11, figs. 13-15; referencias; Mioceno Inferior, Cururu. Paŕ́.

Material - 12 indivíduos coletados.

DESCRIÇño - A respeito da descrição e distribuições geográfica e geológica da espécie, referimos à supracitada publicação de Petri.

Dimensões - Espécime figurado: Diâmetros $0.17 \mathrm{~mm}$ e $0.14 \mathrm{~mm}$; espessura $0.09 \mathrm{~mm}$.

Observações - De modo idêntico a que ocorre no Mioceno de Marajó, a espécie é rara na formação Pirabas.

OCCRRÊNCLLS - Japerica (10), Tauari (15) e Canecos (22a e $23 b$ ).

\section{Globigerina bulloides d'Orbigny}

Globigerina bulloide; d'Orbigny, Ann. Sci. Nat., vol. 7. 1826, p. 277; Modèles n. 17, 76; Recente, Adriático. - Petri Fac. Fil. Ciên. e Letras, Univ. S. Paulo, Bol. Geol. 11, 1954, p. 119 120, Est. 12, figs. 1 3; referências; Mioceno Inferior, Cururu, Pará.

Material - 148 indivíduos coletados.

Descriçĩo - A respeito da descrição e distribuições geográfica e geológica da espécie, referimos à supracitada publicação de Petri.

Dimensões - Espécime figurado: Diâmetros $0.26 \mathrm{~mm}$ e $0,20 \mathrm{~mm}$; espessura $0.16 \mathrm{~mm}$. 
Observações - Como acontece no Mioceno de Cururu, esta espécie é sobrepujarla, na formacão Pirabas, pela espécie Globigerinoides triloba (Reuss).

OCORrÊncias - Urindeua (2), Leôncio (7), Camaleão (8), Japerica (10), Tauari (15), Salinópolis (19) e Canecos (21, 22a e $c$ e $23 b$ e c).

\section{Globigerina sp.}

Est. 8 Fig. 5

Matertal - 3 indivílluos coletados.

DESCRIÇ̃̃o - Testa muito pequena, circular, trocoide bem deprimida, composta de poucas câmaras inflałas, sub-esféricas; lado dorsal plano, lado ventral convexo, todas as voltas do corpo, cêrea de 2 , visíveis do lado dorsal, sòmente a última volta de corpo, formada por 5 câmaras, visível do lado ventral; as câmaras aumentam gradativamente de tamanho; parede grosseiramente perfurada; a abertura consiste em um orifício largo na base da face apertural, na zona umbilical.

Dimensões - Espécime figurado: Diâmetros $0.26 \mathrm{~nm}$ e $0.22 \mathrm{~mm}$; espessura $0.15 \mathrm{~mm}$.

Observações - Estz espécie se assemelha à forma descrita do Mioceno de Marajó (Petri 1954, p. 122) como Globigerina sp. sendo provàvelmente coespecífic'a. Ela lembra a espécie $G$. concinna Reuss a qual, segundo Phleger e Parker $(1951$, p. 34) deve ser referida à G. eggeri Rhumbler. G. concinna Reuss, descrita originalmente como vivente. tem sido citada como fóssil, na província caraíbica, desde o Oligoceno. Preferimos deixar esta espécie sem denominação específica, não só devido à sua raridade, como também devidn ìs incertezas a respeito da sistemática do grupo de globigerinas a que pertencem $G$. cggeri Rhumbler e G. concinna Reuss.

Ocorrências - Fazenda (3) e Canecos (21).

\section{Globigerina? sp.}

Est. 8 Fig. 6

Materiai -2 indivídnos coletados.

Descrição -- Testa pequena, intimamente enrolada, deprimida, bi(onvexa; periferia arredondada tendendo para obtusamente angular, um tainto lobulada; câmaras moderadamente infladas, aumentando gradualmente de tamanho, tornando-se mais largas que altas, especialmente no lado ventral; as faces ventral, periferal e dorsal das câmaras se encontram em ângulo aproximadamente reto, de maneira que a forma das câmaras tende para prismática; cinco câmaras por volta do corpo; suturas deprimidas, mais intensamente no lado ventral onde são radiais, um tanto 
limbadas no lado dorsal; umbílico relativamente grande, aberto; parede lisa, finamente perfurada; a abertura í constituída por uma estreita fenda na base da face apertural, dirigida para o umbílico.

Drmessões -- Espécime figurado : Diâmetro $0.16 \mathrm{~mm}$; espessura 0.06 inm.

Opservações - Não foi possível idlentificar esta interessante espécie com nenhuma conhecida na literatura. Pelo earáter deprimido e ìntimamente enrolado da testa e pelo umbílico grande e aberto lembra as espécies de Globigerina do Cretaceo e Cenozóico Inferior, como por exemplo G. cretacea d'Orbigny, G. almadenensis Cushman e Todd, etc.. Entretanto a testa em nossa espécie é lisa, finamente perfurada, contrastando com a parede rugosa das espécies de Globigerina citadas acima; as câmaras são menos entumecidas e a periferia, por conseguinte, menos lobulada, e com mais tendência a angularidade; a abertura é do tipo de Globorotalia. Pelo caráter prismático das câmaras a nossa espécie lembra certas espécies de Globorotalia tais como G. crassata (Cushman), diferindo desta última pelo caráter liso da parede, deprimido da testa e enrolamento mais compacto. A presença de periferia arredondada afasta esta espécie do gênero Globorotalia.

OCORRÊNCIA - Baunilha (11).

\section{Globigerinoides triloba (Reuss) \\ Est. 8 Fig. 7}

Globigerina triloba Reuss, K. Akad. Wiss. Wien, Math. Nat. Cl. Denkschr, Viena, Austria, vol. 1, 1850, p. 374, Est. 17, figs. $11 a-e$.

Globigerinoides triloba (Reuss), Cushman, Cush. Lab. Foram. Res. Contr. vol. 22, pt. 1, 1946. p. 20 21; Est. 3, fig. 8; Est. 4, figs. 16 18. - Petri. Fac. Fil. Ciên. e Letras. Univ. S. Paulo. Bol. Geol. 11, 1954, p. 122 125, Est. 12, figs. 10 11; referências; Mioceno Inferior, Cururu, Pará,

Material - 394 indivíduos coletados.

Descrição - A respeito da descrição e distribuições geográfica e geológica da espécie, referimos à publicação de Petri citada acima.

Dimensões - Espécime figurado: Diâmetros $0.35 \mathrm{~mm}$ e $0.28 \mathrm{~mm}$.

ObSERvações - Esta é a espécie de foraminífero planctônico mais característica da formação Pirabas pela sua abundância, exatamente como acontece no Mioceno de Cururu. Para discussões sôbre a sistemática desta forma, referimos à supracitada publicação de Petri.

OCorrências - Urindeua (2), Pedrinha (6), Leôncio(7), Camaleão (8), Paracarema (9), Japerica (10), Baunilha Grande (11), Tauari (15), Salinópolis (19) e Canecos $(21,22 a, c$ e $23 b, c, d)$. 


\section{Globorotalia cf. menardii (d'Orbigny) \\ Est. 9 Fig. 1}

Rotalia menardii d'Orbigny, Ann. Sci. Nat., vol. 7, 1826, p. 273; Modèles n. 10, Recente, Adriatico.

Gioborotalia menardii (d'Orbigny), Cushman, U. S. Nat. Mus. Bull. 104, pt. 8, 1931, p. 91 94, Est. 17, fig. 1; Recente, Atlântico. - Petri, Fac. Fil. Ciên. e Letras, Univ. S. Paulo, Bol. Geol. 11, 1954, p. 129 130; Est. 13 figs. 7 9; referências; Mioceno Inferior, Cururu, Pará.

Material - 4 indivíduos coletados.

DESCRIÇ̃̃o - Testa moderadamente alongada, ligeiramente deprimida; lado dorsal plano a ligeiramente convexo, lado ventral convexo, umbilicado; margem periferal fína, carenada, ligeiramente lobulada ; câmaras, em número de 6 na última volta do corpo; suturas ventrais radiais, deprimidas, especialmente as últimas; suturas dorsais niveladas, limbadas; parede lisa; abertura relativamente desenvolvida na base da face apertural, dirigida para o umbílico, com um lábio valvular projeta lo acima.

Dimensões - Espécime figurado: Diâmetros $0.74 \mathrm{~mm}$ e $0.60 \mathrm{~mm}$; espessura $0.30 \mathrm{~mm}$.

Observações - Os nossos espécimes se assemelham a $G$. menardii pelo esbôço da testa e forma e número de câmaras. Êles são contudo menos deprimidos e menos alongados do que aquela espécie. Para os dados sôbre as distribuições geográfica e geológica da espécie, referimos à publi. cação de Petri supracitada.

OCORRÊNCIA - Urindeua (2).

\section{Turborotalia? sp.}

Material - 5 indivíduos coletados.

Descriçĩo - Testa pequena, lado dorsal quase plano, lado rentral convexo; periferia largamente arredonclada, dotada de uma carena em contacto com o lado dorsal ; câmaras distintas, fortemente infladas, aumentando gradativamente de tamauho, de proporçóes miformes, 5 ou 6 na última volta do corpo; suturas distintas, deprimidas e radiais no lado ventral, niveladas ou ligeiramente deprimidas no lado dorsal; umbilíco pequeno no laclo ventral; parede grosseiramente perfurada; a abertura não está clara no nosso material.

Dinensões - Espécime maior : Ḑiâmetros $0.29 \mathrm{~mm}$ e $0.23 \mathrm{~mm}$; espessura $0.14 \mathrm{~mm}$.

()rervações - Os nossos espécimes são semelhantes a $T$ mayeri (Cushman e Ellisor) descrita do Mioceno de Louisiana; contudo a testa 
desta última espécie é mais alongada e as câmaras parecem ser menos entumecidas. Devido à raridade de espécimes, imaturos a maioria, bem como devido ao mau estado de conservação dos mesmos, êles não foram identificados especificamente to nem figurados.

OCorrências - Trindeua (2), Leôncio ( 7 ) e Tauarí (15).

\section{Planulina sp.}

\section{Est. 6 Fig. 9}

Material - j indivíduos coletados.

DescriçÃo - Testa pequena, evoluta em ambos os lados, biconvexa deprimicla; periferia estreitamente arredondada, inteir’a câmaras distintas, aumentando gradual e uniformemente de tamanho, 9 na última volta; duas e meia voltas do corpo são visíveis; suturas distintas, niveladas, ligeiramente curvas e limbadas; parede lisa, grosseiramente perfurada; a abertura é constituída por estreita fenda. limitacla ao bordo periférico da testa.

Dinensões - Espécime figurado: Diâmetros $0.21 \mathrm{~mm}$ e $0.18 \mathrm{~mm}$; espessura $0.04 \mathrm{~mm}$.

Observações - Os exemplares provenientes da formação Pirabas são raros e mal conservados razão porque não se tentou diagnose específica. Pelas suturas só ligeiramente curvas e limbadas êles se afastam da maioria das espécies de Planulina. Esta espécie se assemelha a $P$ charapotoensis Cushman e Stevenson do Mioceno Inferior do Equador, formação Charapoto. Está última espécie possui, contudo, maior número de câmaras por volta do corpo, cêrca de 13, ligeiramente infladas e suturas ligeiramente deprimidas. É possível que os nossos exemplares sejam coespecíficos com a espécie Planulina sp descrita do Mioceno de Marajó (Petri 1954, p. 134).

$$
\text { OCorrências - Baunilha (11), Tauari (15) e Canecos (23d). }
$$

\section{Cibicidina paraensis Petri, sp. nov.}

\section{Est. 9 Fig. 7}

Cibicides americanus (Cushman) var. paraensis Petri, Fac. Fil. Ciên. e Letras, Univ. S. Paulo. Bol. Geol. 11, 1954, p. 135 - 136, Est. 14, figs. 2-4; Minceno Inferior, Cururu, Pará.

Materiat - 46 indivíluos coletados.

Descrição - Testa pequena, lado dorsal plano ou ligoiramente convexo, laclo ventral bem convexo; periferia aguda, carenata; camaras, cêrca de 7 a 8 na última rolta do corpo, aumentando graclualmente de tamanho; suturas clistintas, limbarlas em ambos os lados, eurvas para a abertura; região umbilical preenchida. em ambos os lados, por material fre- 
quentemente transparente, deixando ver, por transparência, as voltas anteriores, quando a testa está bem conservada; parede lisa, finamente perfurada; abertura periferal, estendendo-se para o lado dorsal.

Dimensões - Espécime figurado : Diâmetros $0.23 \mathrm{~mm}$ e $0.20 \mathrm{~mm}$; espessura $0.08 \mathrm{~mm}$.

Observações - A forma proveniente de Castelo, e descrita por Petri (1952, p. 34-35; Est. IV, figs. 7-8) como Gyroidina? sp., possivelmente deva ser incluida aqui. $\Lambda$ exata identificação dessa forma é dificultada, pela presença de rocha matriz cobrindo parte da testa. A curvatura dos septos é semelhante mas a forma possui maior número de câmaras do que o normal para Cibicidina paraensis Petri. clor'sal.

Este gênero distingue-se de Cibrcides pelo caráter involuto do lado

Cibicidina paraensis Petri distingue-se de C. americanus (Cuhman), por fiossuir as suturas mais curvas e pela testa mais decididamente planoconvexa. Ela se distingue de $C$. manricensis (Howe e Roberts) pela ausência de granulações próximo a região umbilical, carena mais claramente desenvolvida e aumento mais brussco das câmaras. Distingue-se de $C$. danvillensis (Howe e Wallace), pela região umbilical de ambos os lados coberta por máteria hialina transparente e pela presença de unna carena bem distinta.

OCORnÊNCIAS - Urindeua (2), Pedrinha (6), Leôncio (7), Japerica (10), Tauari (15), Salinópolis (19) e Canecos (22a e $c$ e $23 b, c$ e $d$ ).

\section{Cibicides lobatulus (Walker e Jacob) \\ Est. 9 Fig. 5}

Nautilus lobatulus Walker e Jacob Adams Essays, Kanmacher's ed., 1798, p. 642; Est. 14, fig. 36.

Cibicides lobatula (Walker e Jacob), Cushman, U.S. Nat. Mus., Bull. 104, pt. 8, 1931, p. 118 120, Est. 21, figs. $3 a c$; Recente, Atlântico.

Cibicides lobatus (d'Orbigny), Galloway e Heminway, New York Acad. Sci., vol. 3, pt. 4, 1941, p. 393, Est. 24, fig. 4; Oligoceno e Mioceno, Pôrto Rico. - Petri, Fac. Fil. Ciên. e Letras, Univ. S. Paulo, Bol. Geol. 11, 1954, p. 137 138, Est. 14, figs. 10 12; referências; Mioceno Inferior, Cururu, Pará

Cibicides lobatulus (Walker e Jacob). Cole, Flórida St. Geol. Surv. Bull. 6, 1931, p. 56; Plioceno e Pleistoceno, Flórida.

Material - 35 indivíduos coletados.

Descrição - Testa deprimida, com o lado dorsal plano ou côncavo a o) rentral moderadamente convexo; periferia aguda, carenada, lobulada; volta do corpo constituída por 7 a 8 câmaras; suturas distintas, ligeira. mente deprimidas e aproximadamente radiais no lado ventral, niveladas, ligeiramente limbadas e curvas no lado dorsal; parede lisa, grosseiramente 
perfurada no lado dorsal, mais finamente no lado ventral; abertura estendendo-se para o lado dorsal.

Dimensões - Espécime figurado: Diâmetros $0.30 \mathrm{~mm}$ e $0.24 \mathrm{~mm}$; espessura $0.11 \mathrm{~mm}$.

Observações - A literatura sôbre esta espécie é confusa. Formas parecidas e possivelmente coespecíficas têm sido descritas ora como C. lobatulus (Walker e Jacob) ora como C. lobatus (d'Orbigny). A forma descrita de Marajó como C. lobatus (d'Orbigny) se assemelha ao exemplar figurado por Bermudez (1949, Est. 25, figs. 46 48) como C. lobatus (a'Orbigny) por possuir o lado dorsal parcialmente evoluto enquanto na forma de Pirabas êsse lado é inteiramente evoluto, aproximando-se nêsse sentido, do holótipo figurado por Walker e Jacob (Em Ellis e Messina, 1940, Nautilus lobatulus Walker e Jacob). $23 d)$.

OCorrênCIAS - Japerica (10), Tauari (15) e Canecos $(21,22$ c e

\section{Cibicides pirabensis Petri, sp. nov. Est. 9 Figs. 2, 3}

Material - 441 indivíduos coletados.

Descrição - Testa pequena, aproximadamente circular; lado dorsal plano, completamente evoluto, lado ventral fortemente convexo, involuto: duas voltas são visíveis no lado dorsal; a região ventral da testa é preenchida, no lado dorsal, por depósito conchífero; umbílico inexistente; periferia ligeiramente lobulada, com 1 guilha separando os lados dorsal e ventral; câmaras aumentando gradualmente no lado dorsal e ràpidamente no lado ventral, sendo o aumento em largura e espessura maior do que o aumento em comprimento; íltima volta do corpo formada por 8 a 9 câmaras; suturas dorsais um tanto oblíquas, niveladas com o resto da testa; suturas ventrais ligeiramente deprimidas, radiais e ligeiramente curvas; parede grosseiramente perfurada $n$ no lado dorsal e finamente no lado ventral; a abertura consiste $\mathrm{am}$ 1 fenda pequena na base da face apertural, iniciando-se bem próxima a periferia e se estendendo atravéz desta para o lado dorsal, ao longo da sutura axial, por uma distância de cêrea de 2 câmaras; ela é dotada de um pequeno lábio superior.

Dimensões - Espécimes figurados: 1) Diâmetros $0.29 \mathrm{~mm}$ e 0.26 $\mathrm{mm}$; espessura $0.14 \mathrm{~mm}$. 2) Diâmetros $0.23 \mathrm{~mm}$ e $0.20 \mathrm{~mm}$; esp’sisura $0.12 \mathrm{~mm}$.

ObSERVAÇÕes - Esta espécie pertence a secção do gênero Cibicides caracterísada por formas fortemente plano-convexas, com testa aproximadamente circular e cơm câmaras largas e baixas. As espécies de Cibicides dêste tipo são numerosas, na província caraíbica, no Oligoceno e Mioceno, tornando-se mais raras em sedimentos mais jovens, chegando, contudo, até os nossos dias. 
A nossa espécie, vista do lado ventral, se assemelha a Cibicides dalmatina Van Bellen, do Eoceno da Iugoslávia. Contudo ela possui menor número de câmaras por volta do corpo as quais são, portanto, proporcionalmente maiores (9 na presente espécie, 12 na de Van Bellen) e a testa é, proporcionalmente, mais alta. Esses caracteres tornam as vistas periferais dessas 2 espécies bem diferentes.

A nossa espécie não se assemelha estreitamente a nenhuma das espécies fortemente plano-convexas da província caraíbica. Difere de C. dohmi Bermudez, do Mioceno Inferior de São Domingos, pelo menor número de câmaras por volta do corpo (14 a 15 na espécie de Bermudez) e pelo caráter não limbado das suturas; de $C$. granulosus Bermudez, do Oligoceno Médio de São Domingos, pela ausência de ornamentação na zona central do lado dorsal; de C. Lunteri Bermudez, também do Oligoceno Médio de São Domingos, pela periferia carenada e ausência de ornamentação da testa; de C. mexicumus Nuttall, do Oligoceno do México, pela ausência de zona elevada na parte central do lado dorsal, pelo menor número de câmaras por rolta do corpo e pela parede mais finamente perfurada

Esta é uma das espécies mais características da formação, sendo comum em quase todos os afloramentos constituindo, portanto, um dos elos de ligação das diferentes fâunulas descritas, não sendo conhecida até agora, fora da bacia de sedimentação da formação Pirabas.

Ocorrências - Urindeua (2), Fazenda (3), Castelo (5), Pedrinha (6), Leôncio (7), Japerica (10), Tauari (15), Salinópolis (19) e Cane$\cos (21,22 a$ e c e $23 b, c$ e $d)$.

\section{Cibicides pseudoungerianus (Cushman) \\ Est. 9 Fig. 6}

Truncatulina ungeriana Brady (Non Rotalina unceriana d'Orbigny), Rep. Voy Challenger Zool., vol. 9, 1884, Est. 94, fig. 9; Recente, Irlanda.

Truncatulina pseudoungeriana Cushman, U.S. Geol. Surv., Prof. Paper 129, 1922. p. 97, 136; Est. 20, fig. 9; Oligoceno, formação Byran Marl, Mississipi.

Cibicides pseudoungerianus (Cushman), Cole e Gillespie, Bull. Am. Pal. vol. 15, n. 57 b 193(', p. 15, Est. 3, fiğs. 10, 11; Oligoceno Médio, formação Meson, México. - Petri. Fac. Fil. Ciên. el Letras, Univ. S. Paulo Bol. Geol. 11, 1954, p. 138, 139; Est. 14, fig̣s. 1618 ; referêneias; Mioceno Inferior, Cururu, Parí.

Material - 76 indivíduos coletados.

DESCRIÇÃo - Testa pequena, aproximadamente circular, deprimida, biconvexa, com convexidade maior no lado ventral; periferia aguda, carenada; cêrea de nove câmaras na última volta do corpo; suturas distintas, limbadas tanto no lado dorsal como ventral; nêste lado elas são niveladas e 
fundidas no centro, formando pequena massa umbonal; as primeiras voltas no lado dorsal são cobertas por material conchífero; parede grosseiramente perfurada; abertura se estendendo em pequena extensão ao longo do lado dorsal.

Dimensões - Espécime figurado: Diâmetros $0.20 \mathrm{~mm}$ e $0.18 \mathrm{~mm}$; es pessura $0.09 \mathrm{~mm}$.

Orservações - Os espécimes de Pirabas são todos pequenos de maneira que êles não podem ser comparados diretamente com o exemplar proveniente de Cururu, figurado por Petri (1954, Est. 14. figs. 16 18). Se compararmos, contudo, os nossos espécimes, com formas jovens provenientes de Cururu, a semelhança entre os dois materiais torna-se mais estreita.

Como mostrou Galloway e Heminway (1941, p. 395-396) esta aspécie é afim a C. floridanus (Cushman), distinguindo-se desta última sòmente pelas suturas menos limbadas e não eleradas, e pelos depósitos conchíferos mais tinos.

OCORRÊncias - Pedrinha (6), Leôncio (7), Japerica (10), Tamari (15), Salinópolis (19) e Canecos (22a e 23b, $c$ e d).

\section{IX - BIBLIOGRAFIA}

Bermudez, P J. - (1949) Tertiary smaller Foraminifera of the Dominican Republic - Cush. Lab. Foram. Res., Sp. Publ. 25, 322 p., 6 figs., 26 t., 1 tab.

Bermudez P. J. - (1950) Contribución al estudio del Cenozoico cubano. - Mem. Soc. Cubana Hist. Nat., v. 19, n. 3, p. 205 375, 2 tab.

Bermedfz, P. J. (1952) - Estudio sistemático de los foraminiferos rotaliformes Bol. Geol. Min. Minas e Hidrocarburos, Venezuela, v. 2, n. 4, 230 p., 35 t.

Branner, J. C. - (1919) Resumo da Geologia do Brasil para acompanhar o mappa geológico do Brasil - Geol. Soc. Am., v. 30, n. 2, p. 96.

Carvalho, P. F. - (1926) Reconhecimentos Geológicos entre a costa atlântica de Maracanã e Pirabas e a estação experimental na estrada de ferro de Bragança - Serv. Geol. Miner. Brasil, Bol. 15, p. 115 118, 1 mapa.

Coryell, H. N. e Rivero, F C. - (1940) A Miocene microfauna of Haiti - Jour. Pal., v. 14 , n. 4 , p. 324344,4 t.

Cushman, J. A. - (1931) The Foramifera of the Atlantic Ocean - U. S. Nat. Mus. Bull, 104, pt. 4, p, 46, t. 8, figs. 12, 13.

Cushman, J. A. - (1931) The Foraminifera of the Atlantic Ocean - U.S. Nat. Mus. Bull. 104, pt. 8, 179 p., 26 t. 
Cushuan, J. A. - (1937) A Monography of the subfamily Virgulininae of the Foraminiferal family Buliminidae - Cush. Lab. Foram. Res., Sp. Publ. 9, 228 p., 24 t.

Cushuan, J. A. - (1948) Foraminifera; their classification and economic use, 4a. ed. -- Harvard Univ. Press, 605 p., 31 figs., 55 t.

Cushuan, J. A. e Jarvis, P W. - (1930) Miocene Foraminifera from Buff Bay, Jamaica - Jour. Pal., v. 4, n. 4, p. 353 368, 3 t.

Cushman, J. A. e Parker, F. L. - (1931) Recent Foraminifera from the Atlantic coast of South America - U. S. Nat. Mus., Proc.. vol. 80, Art. 3, 24 p., 4 t.

Cushman, J. A. e Todd, R. - (1945) Miocene Foraminifera from Buff Bay Jamaica - Cush. Lab. Foram. Res., Sp. Publ. 15, 73 p, 12 t.

Ellis, B. F e Messina, A. R. - (1940) Catalogue of Foraminifera - Am. Mus. Nat. Hist., New York.

Galloway, J. J. e Heminway, C. E. - (1941) The Tertiary Foraminifera of Porto Rico - Sci. Surv. of Porto Rico and the Virgin Islands, vol. 3, pt. 4, 490 p., 36 t., 4 tab., l- mapa.

Hofker, J. - (1954) Notes on the generic names of some rotaliform Foraminifera -- The Micropaleontologist vol. 8, n. 4, p. 34, 35.

Hornвrook, N. B. e V.lla, P. - (1954) Notes on the generic names of some rotaliform Foraminifera - The Micropaleontologist vol. \&, n. 1, p. 2423.

Linde, R. A. - (1946) The Geology of Venezuela and Trinidad - 2a. ed. - Pal. Res. Inst., 890 p. 90 t., mapas.

Malrky, C. J. -.. (1924) Fósseis terciários do Brasil com descrição de novas formas rretáceas - - Serv. Geol. Miner. Brasil, Monogr. 4, 431 p., 24 t.

Nittall, W. L. F - (1928) Tertiary Foraminifera from the Naparima region of Trinidad (British West Indies) - Geol. Soc. London, Quar.t. Jour., vol. 84. n. 333 , p. 57115.

Olveira, S. e Petri, S. - (1952) Reconhecimento geológico na área de exposiformação Agricola. Min. Agricultura.

Oliveira, S. e Petri, S. - (1952) Reconhecimento geológico na área de expositção da formação Pirabas, Estado do Pará, Brasil - Rev.. Esc. Minas Ouro Preto, Ano 17, n. 1, p. 9 15, 3 mapas 2 perfís.

Palmer, D. K. - (1945) Notes on the Foraminifera from Bowden, Jamaica Bull. Am. Pal., vol. 29, n. 115, p. 5 82, 2 t.

ParR, W. J. - (1947) The Lagenid Foraminifera and their relationship - Proc. Roy. Soc. Victoria vol. 58, n. ser. 1 fig., p. 116 130, 2 t.

Petri, S. - (1952) Ocorrências de foraminíferos fósseis no Brasil - Bol. Fac. Fil. Ciên. Letr., Univ. S. Paulo, 134, Geologia n. 7, p. 21-42, 2 figs., 3 fotos, 4 t.

Petri, S. - (1954) Foraminíferos fósseis da Bacia do Marajó - Bol. Fac. Fil. Ciên. Letr., Univ. S. Paulo, 176, Geologia n. 11. 172 p., 14 t., 10 figs., 3 tab.

Phleger, F. B. e Parker, F. L. - (1951) Ecology of Foraminifera, Northwest Gulf of México - Geol. Soc. Am., Mem. 46, pt. 2, 64 p., 20 t.

Redmond, C. D. - (1949) What is the genus Eponides? -- The Micropaleontogist, vol. 3 , n. 4 , p. 1921,1 t. 
Redmond, C. D. -- (1953) Miocene Foraminifera from the Tubara beds of Northern Colombia - Jour. Pal. vol. 27, n. 5, p. 708 733, 4 t., 1 fig.

Revz, H. H. - (1942) Stratigraphy of Northern South America, Trinidad anu Barbados - Proc. 8 th. Am. Sci. Congr., vol. 4, Geological Sci., p. 513 57], 1 tab.

Renz, H. H. - (1948) Stratigraphy and faunc of the Agua Salada group, State of Falcon, Venezuela - Geol. Soc. Am., Mem. 32, 219 p., 12 t., 19 tab.

StoLi, H. - (1951) Estudo preliminar das relaçôes entre a Geologia e a Limnologia da zona bragantina (Pará) - Inst. Agron. do Norte, Bol. 24, p. 67 76, 3 tab., 2 fotos, 1 mapa.

Twenhoffel, W. H. -- (1950) Principles of Sedimentation, 2a. ed. - Mc-GrawHill Book Co., Inc.

White, C. A. -- (1887) Contribuições à Paleontologia do Brasil - Mus. Nac. Rio de Janeiro, Arch., vol. 7, 273 p., 28 t.

Woodring, W. P. - (1925) Miocene Mollushs from Bowden, Jamaica, Pt. 1. Pelecypods and Scaphopods - Carnegie Inst. Washington, Publ. 366, 222 p., 28 t.

Woodring, W. P. - (1928) Miocene Mollu'ks from Bowden, Jamaica: Pt. 2. Gastropods - Carnegic Inst. Washington, Publ. 385564 p., 40 t. 


\section{ESTAMPA 1}

f'igs. $1 \mathrm{a}-\mathrm{b}-$ Haplophragmoides sp. $-85 \mathrm{x}-$ Japerica (Afloramento 10)

Figs. 2 a - c - Trochammina japericensis Petri, sp. nov. - 85 x - Marapanim (17)

Figs. $3 \mathrm{a}-\mathrm{c}-$ Idem $85 \mathrm{x}$ - Japerica (10)

Figs. 4 a - c - Idem $85 \mathrm{x}-$ Japerica (10)

Figs. $5 \mathrm{a}-\mathrm{b}-$ Spiroplectammina japericensis Petri, sp. nov. $-20 \mathrm{x}-$ Japerica (10)

Fig. $6-S(?)$ sp. $-85 \mathrm{x}-$ Japerica (10)

Figs. $7 \mathrm{a}-\mathrm{b}-$ Textularia japericensis Petri, sp. nov. $-40 \mathrm{x}-$ Japerica (10)

Figs. $8 \mathrm{a} \cdot \mathrm{b}-$ Idem_- $_{-} 40 \mathrm{x}$ - Japerica (10)

Figs. $9 \mathrm{a}-\mathrm{b}-T$ sp. $-20 \mathrm{x}-$ Japerica (10)

Figs. 10 a - c - Quinqueloculina fusiformis Petri, sp. nov. - $40 \mathrm{x}-$ Castelo (5).

Figs. 11 a c c - Idem -- $30 \mathrm{x}$ - Castelo (5)

Figs. 12 a $-c-Q$. lamarckiana d'Orbigny $-67 \times-$ Pedrinha (6) 


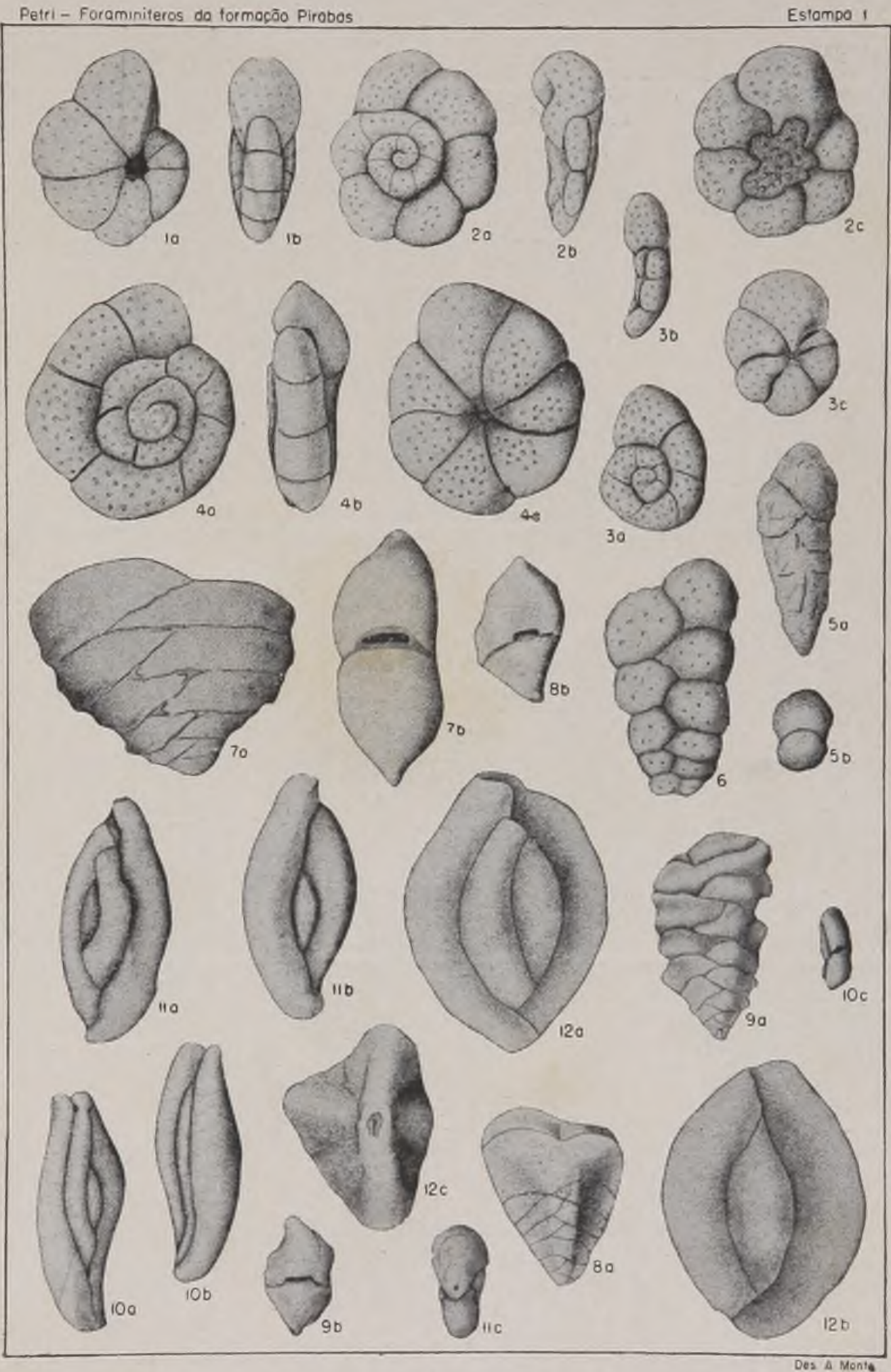




\section{ESTAMPA 2}

Figs. 1 a c - Quinqueloculina seminula (Linné) - 85 x - Baunilha Grande (11)

Figs. 2 a c - Idem - 85 x - Salinópolis (19)

Figs. 3 a c - Q. sp. -40 x - Pedrinha (6)

Figs. 4 a c - Idem - $85 \mathrm{x}$ - Salinópolis (19)

Fig. $\quad$ i $\quad-$ Idem - $85 \mathrm{x}$ - Salinópolis (19)

Figs. 6 a c - Triloculina oblonga (Montagu) - 85 x - Salinópolis (19)

Figs. 7 a c - T. sp. $-85 \mathrm{x}-$ Pedrinha (6)

Figs. 8 a c - Pyrgo subsphaerica (d'Orbigny) - 40 $\mathrm{x}$ - Japerica (10)

Figs. 9 a b - Idem - $85 \mathrm{x}$ - Salinópolis (19)

Fig. 10 - Archaias angulata (Fichtel e Moll) - $20 \mathrm{x}$ - Castelo (5) 


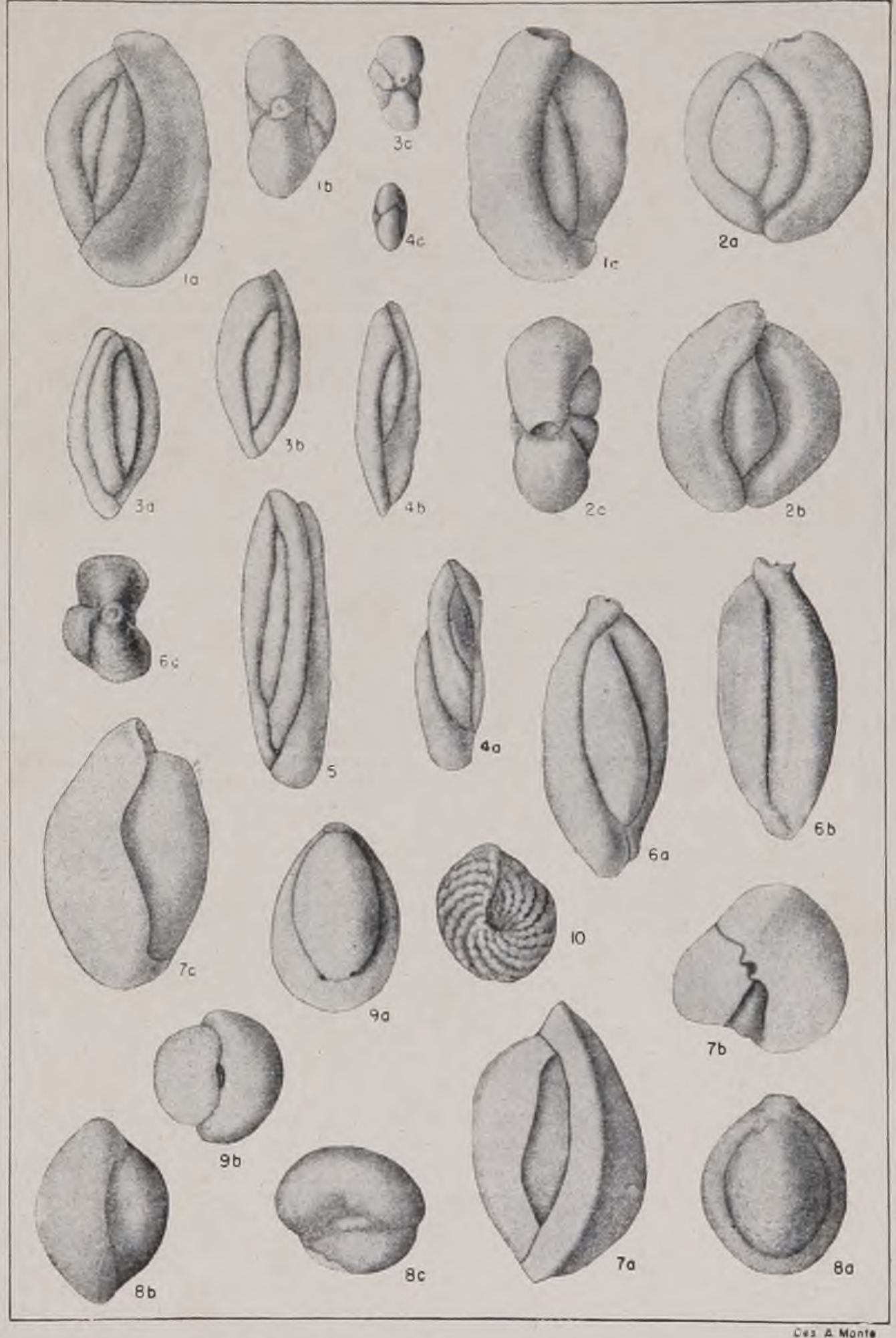




\section{ESTAMPA 3}

Figs. 1 a c - Pyrgo sp. - $40 \mathrm{x}$-Salinópolis (19)

Figs. 2 a c - Darbyella? sp. $-85 \mathrm{x}-$ Pedrinha (6)

Fig. $3-$ Nodosaria sp. $-85 \mathrm{x}-$ Japerica (10)

Fig. 4. - Dentalina aff. consobrina d'Orbigny $-20 \mathrm{x}-$ Japerica (10

Fig. $5-$ D. sp. $-85 \times$ - Canecos (21)

Fig. 6 - Lagena bulloides Petri, sp. nov. $-67 \mathrm{x}-$ Salinópolis (19)

Fig. $7-$ L. cf. perlucida (Montagu) $-85 \mathrm{x}-$ Salinópolis (19)

Fig. $8-$ L. cf. substriata Williamson $-85 \mathrm{x}$ - Canecos (22a)

Fig. $9-$ L. sp. $-85 \mathrm{x}-$ Canecos (23b)

Figs. 10 a b - Fissurina depressula Petri, sp. nov. $-85 \mathrm{x}$ - Japerica (10)

Figs. 11 a b $-F$ laevigata Reuss - $85 \mathrm{x}$ - Salinópolis (19)

Figs. 12 a $\mathrm{b}-$ Idem $-85 \mathrm{x}-$ Salinópolis (19)

Figs. 13 a b - Oolina nuttalli (Galloway e Heminway) - 85 x - Japerica (10)

Figs. 14 a b - Parafissurina ? hemisphaerica Petri, sp. nov. - Salinópolis (19)

Figs. 15 a b - Polymorphina sp. $-85 \mathrm{x}-$ Salinópolis (19)

Figs. 16 a b - Pseudopolymorphina tropicale Petri, sp. nov. $-85 \mathrm{x}-$ Salinópolis (19) 


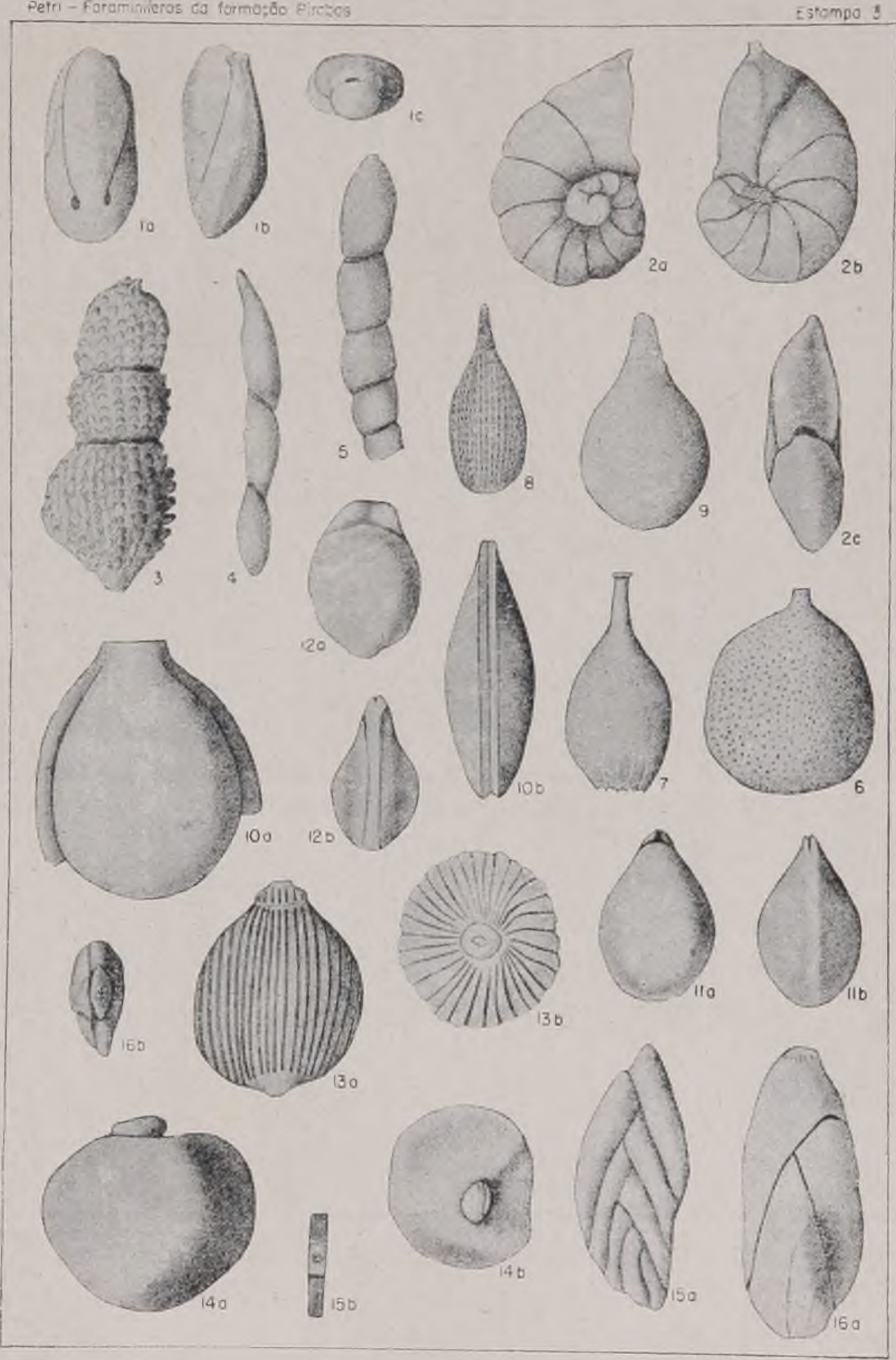

ces 4 minte 


\section{ESTAMPA 4}

Figs. 1 a c - Guttulina irregularis (d'Orbigny) - $85 \mathrm{x}-$ Leôncio (7)

Figs. 2 a c - Globulina tropicale Petri, sp. nov. - 85 x - Salinópolis (19)

Figs. 3 a b - Nonion canecensis Petri, sp. nov. - $85 \mathrm{x}$ - Canecos (22c)

Figs. 4 a c - Nonionella pirabensis Petri, sp. nov. - $60 \mathrm{x}$ - Leôncio (7)

Figs. 5 a c - Idem - Exemplar jovem - 85 x - Canecos (21)

Figs. 6 a $\mathrm{b}$ - Elphidium poevanum (d'Orbigny) - $85 \mathrm{x}$ - Tauari (15)

Figs. 7 a b - E. sp. $-85 \mathrm{x}-$ Canecos (21)

Figs. 8 a b $-E$. poeyanum (d'Orbigny) $-85 \mathrm{x}$ - Canecos (21)

Figs. 9 a b - E. sagrai (d'Orbigny) var. cururuensis Petri $-85 \mathrm{x}-$ Tauari (15)

Figs. 10 a b - Idem - Exemplar jovem - $85 \mathrm{x}$ - Japerica (10)

Fig. $11-$ Buliminella ? sp. $-85 \mathrm{x}-$ Salinópolis (19) 


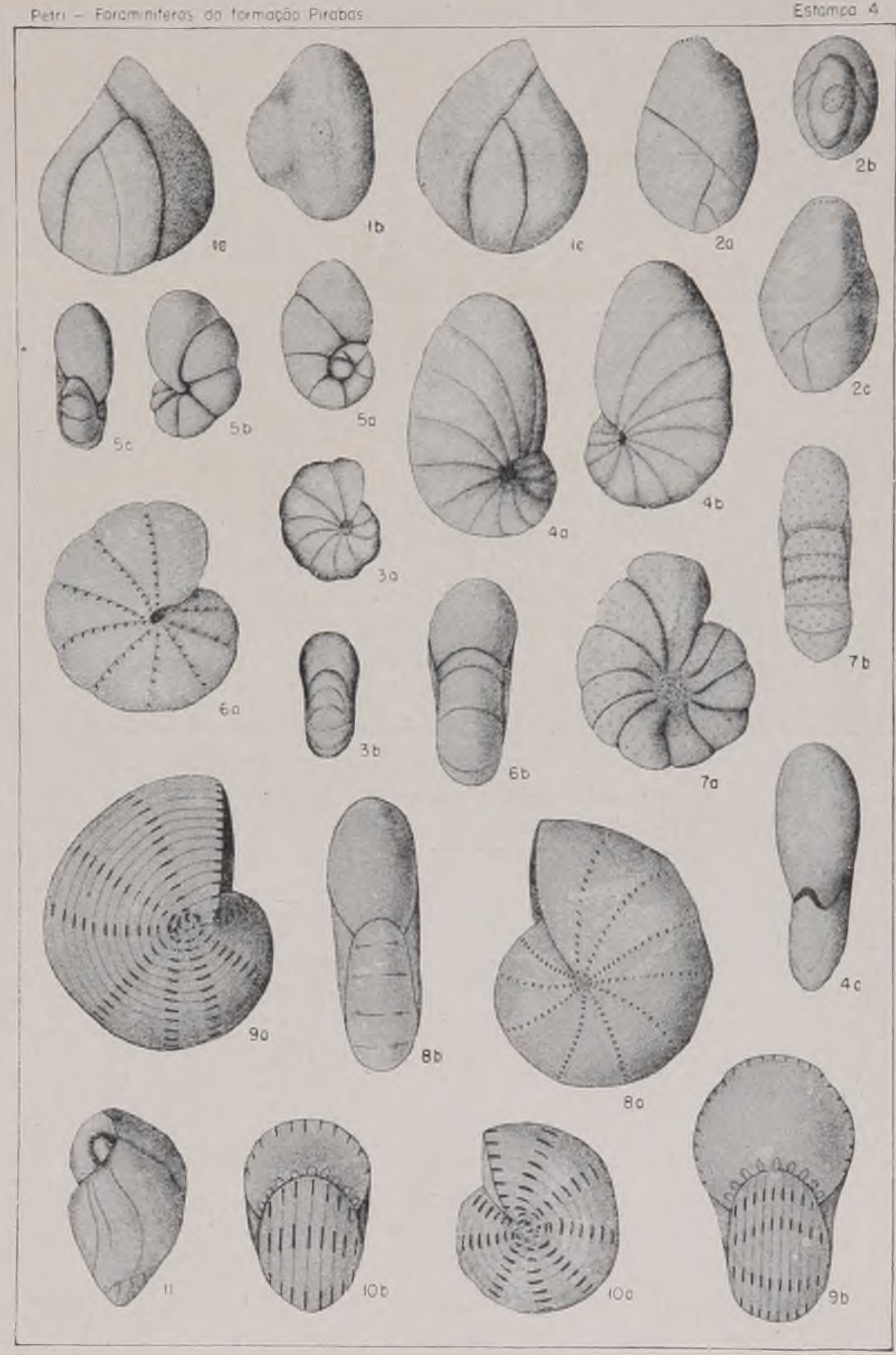




\section{ESTAMPA 5}

Figs. 1 a $\mathrm{b}-$ Bolivina pirabensis Petri, sp. nov. $-85 \mathrm{x}-$ Canecos (21)

Figs. 2 a b - B. piraben is ? - $85 \mathrm{x}-$ Canecos (21)

Figs. 3 a b - B. plicatella Cushman $-85 \mathrm{x}$ - Japerica (10)

Figs. 4. a b - B. tortuosa Brady $-85 \mathrm{x}-$ Tauari (15)

Figs. 5 a b - B. sp. $-85 \mathrm{x}-$ Canecos (23d)

Figs. 6 a $b-B$. sp. $-85 \mathrm{x}$ - Japerica (10)

Figs. 7 a $\mathrm{b}$ - Angulogerina hughesi (Galloway e Wissler) - $85 \mathrm{x}-$ Fazenda (3)

Figs. 8 a b - A. paraensis Petri, sp. nov. $-85 \mathrm{x}-$ Japerica (10)

Figs. 9 a b - Idem - Exemplar jovem - $85 \mathrm{x}$ - Japerica (10)

Figs. $10 \mathrm{a}$ b - Spirillina cf vivipara - Ehrenberg - 85 x - Japerica (10)

Figs. 11 a c - Discorbis paraensis Petri, sp. nov. - $85 \mathrm{x}$ - Canecos (21)

Figs. 12 a c - Idem - $85 \mathrm{x}$ - Salinópolis (19)

Figs. 13 a c - Idem - Exemplar jovem - $85 \mathrm{x}$ - Canecos (22c)

Figs. 14 a c - Discorbis ? sp. - $85 \mathrm{x}$ - Canecos (22a)

Figs. 15 a $\mathrm{b}-$ Operculina ? sp. -23 x -- Salinópolis (19) 


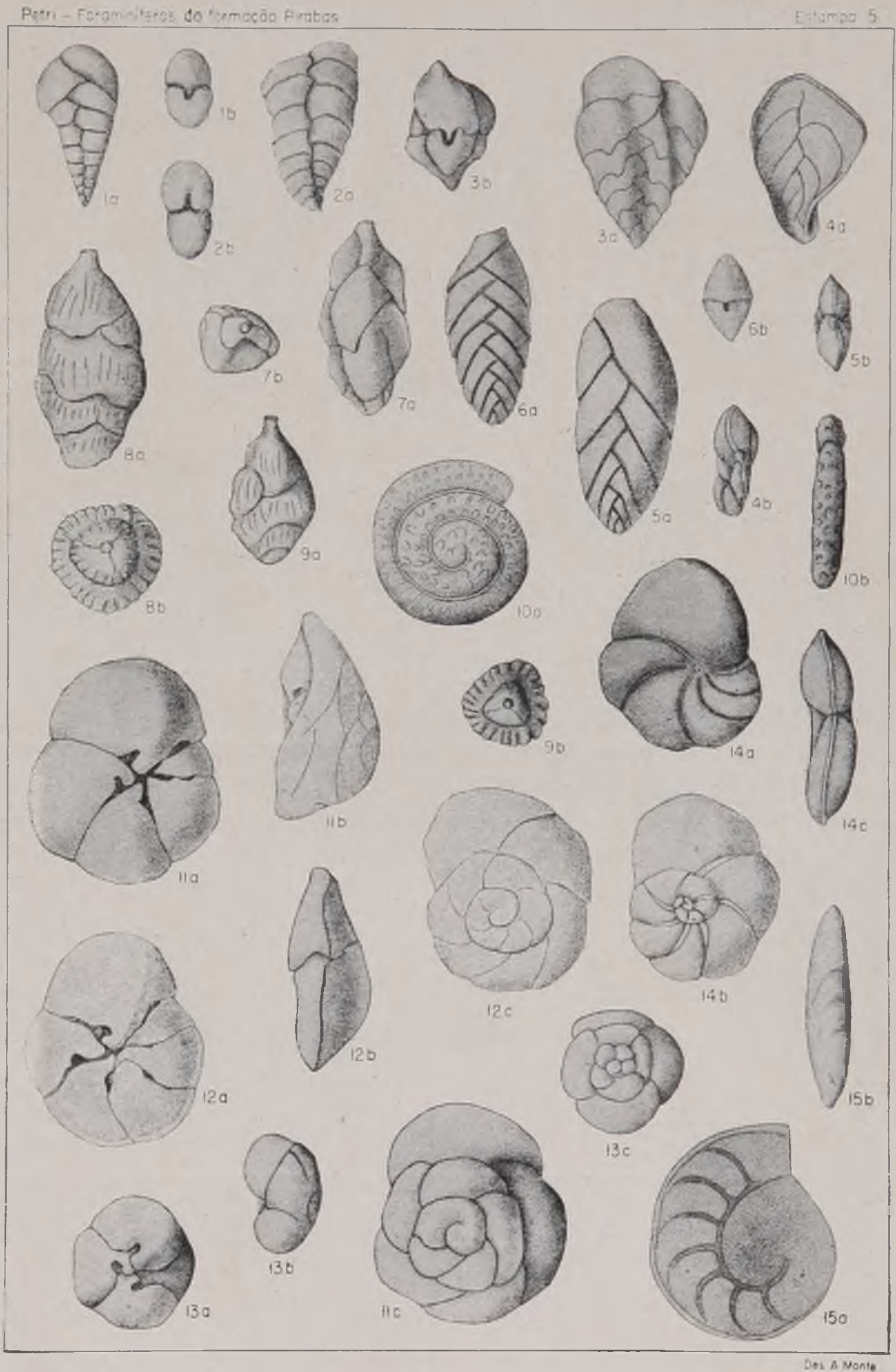




\section{ESTAMPA 6}

Figs. 1 a c - Discopulvinulina pirabensis Petri, sp. nov. $-85 \mathrm{x}$ - Canecos (21)

Figs. 2 a c - Conorbella americana Petri, sp. nov. $-67 \times$ - Salinópolis (19)

Figs. 3 a c - Neoconorbina terquemi (Rzehak) - $50 \mathrm{x}$ - Salinópolis (19)

Figs. 4. a c Eponides repandus (Brady) - $43 \mathrm{x}$ - Urindeua (2)

Figs. 5 a $\mathrm{c}-E$ ? sp. $-43 \mathrm{x}$ - Urindeura (2)

Figs. 6 a c - Siphonina pulchra Cushman - $100 \mathrm{x}$ - Japerica (10)

Figs. 7 a c -.- Pseudobulimina? sp. - $85 \times$ - Canecos (21)

Figs. 8 a b - Cassidulina laevigata d'Orbigny - $85 \times$ - Japerica (:0)

Figs. 9 a $\mathrm{b}-$ Planulina sp. $-85 \mathrm{x}-$ Canecos (23d) 


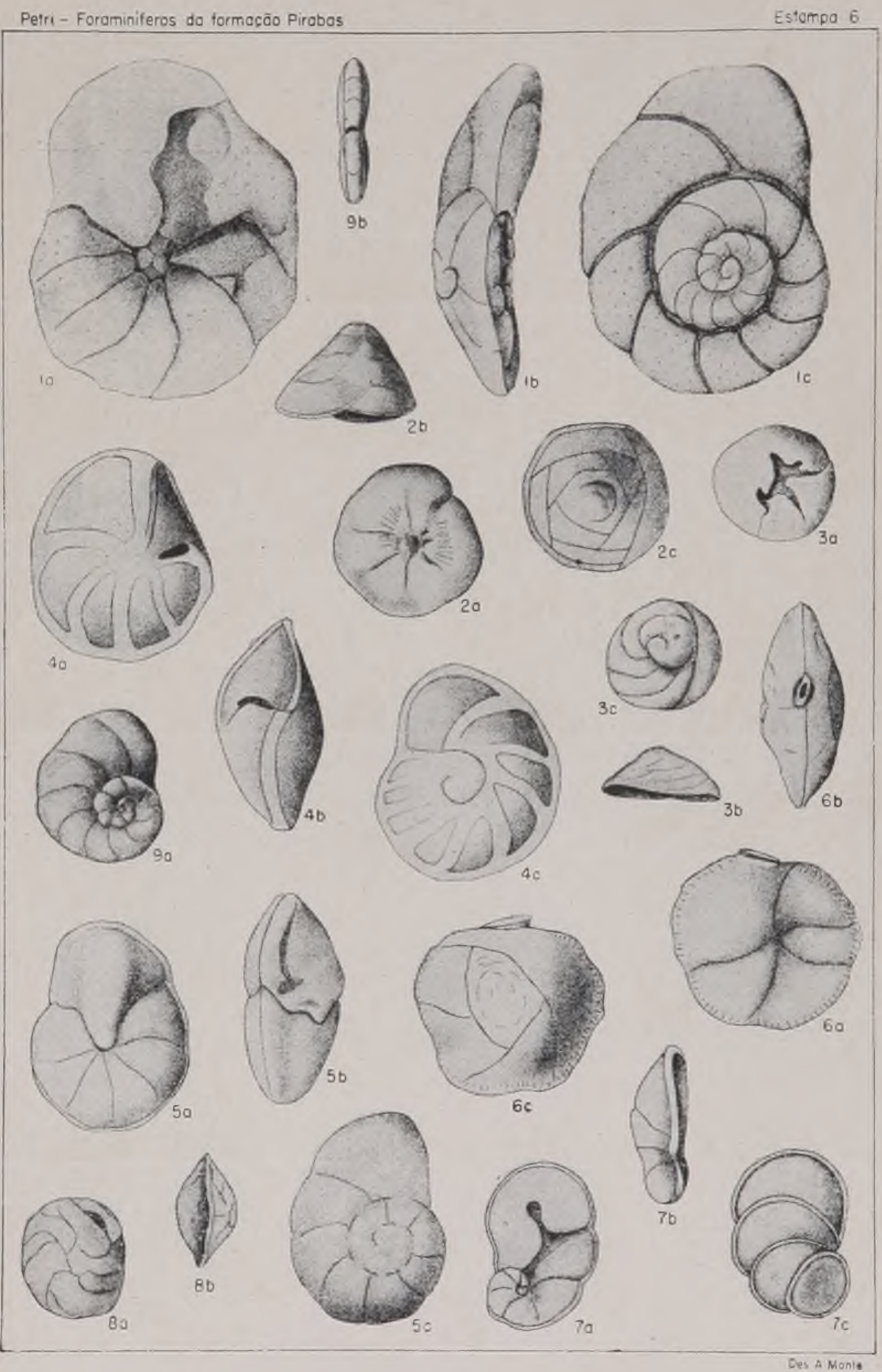




\section{ESTAMPA 7}

Figs. 1 a c - Streblus beccarii (Linné) var. mendesi Petri $-85 \mathrm{x}$ - Canecos (21) Figs. 2 a $\quad$ c - Idem $-85 \mathrm{x}-$ Salinópolis (19)

Figs. 3 a c - Idem - 85 x - Sondagem Cururu - Amostra Calha (543 m $549 \mathrm{~m}$ )

Figs. 4 a c - Idem - $85 \mathrm{x}$ - Sondagem Cururu - Amostra Calha (512 m $524 \mathrm{~m}$ )

Figs. 5 a c - S. catesbyanus (d'Orbigny) var. tepida (Cushman) $85 \mathrm{x}$ - Cane$\cos (21)$

Figs. 6 a c -- Idem - Exemplar jovem - 85 x -- Canecos (21) 
Petri - Foraminiteros da tormacâa Pirabos
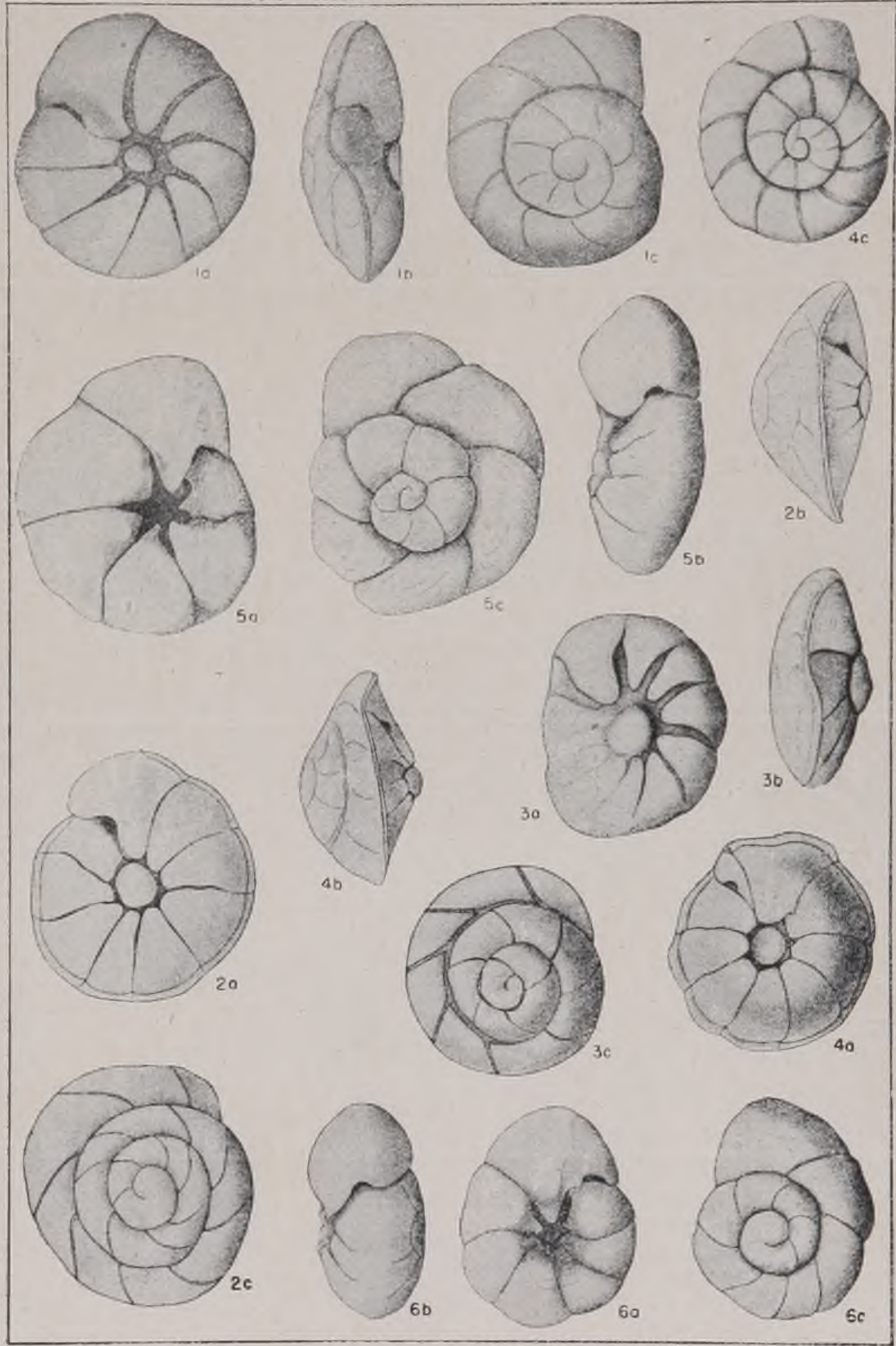


\section{ESTAMPA 8}

Figs. 1 a c - Amphistegina lessonii d'Orbigny - $22 \mathbf{x}$ - Salinópolis (19)

Figs. 2 a $c-A$. lessonii d'Orbigny var. conica Petri $-85 \mathrm{x}$ - Pedrinha (6)

Figs. 3 a $\quad$ c - A. lessonii d'Orbiogny var. tumida Petri $-22 \mathrm{x}$ - Salinópolis (19)

Figs. 4 a c - Globigerina bulloides d'Orbigny $-115 \mathrm{x}$ - Japerica (10)

Figs. 5 a $\mathrm{c}-$ G. sp. $-85 \mathrm{x}-$ Canecos (21)

Figs. 6 a c - G. ? sp. - 85 x - Baunilha Grande (11)

Fig. 7 - Globigerinoides triloba (Reuss) - $85 \mathrm{x}-$ Japerica (10) 


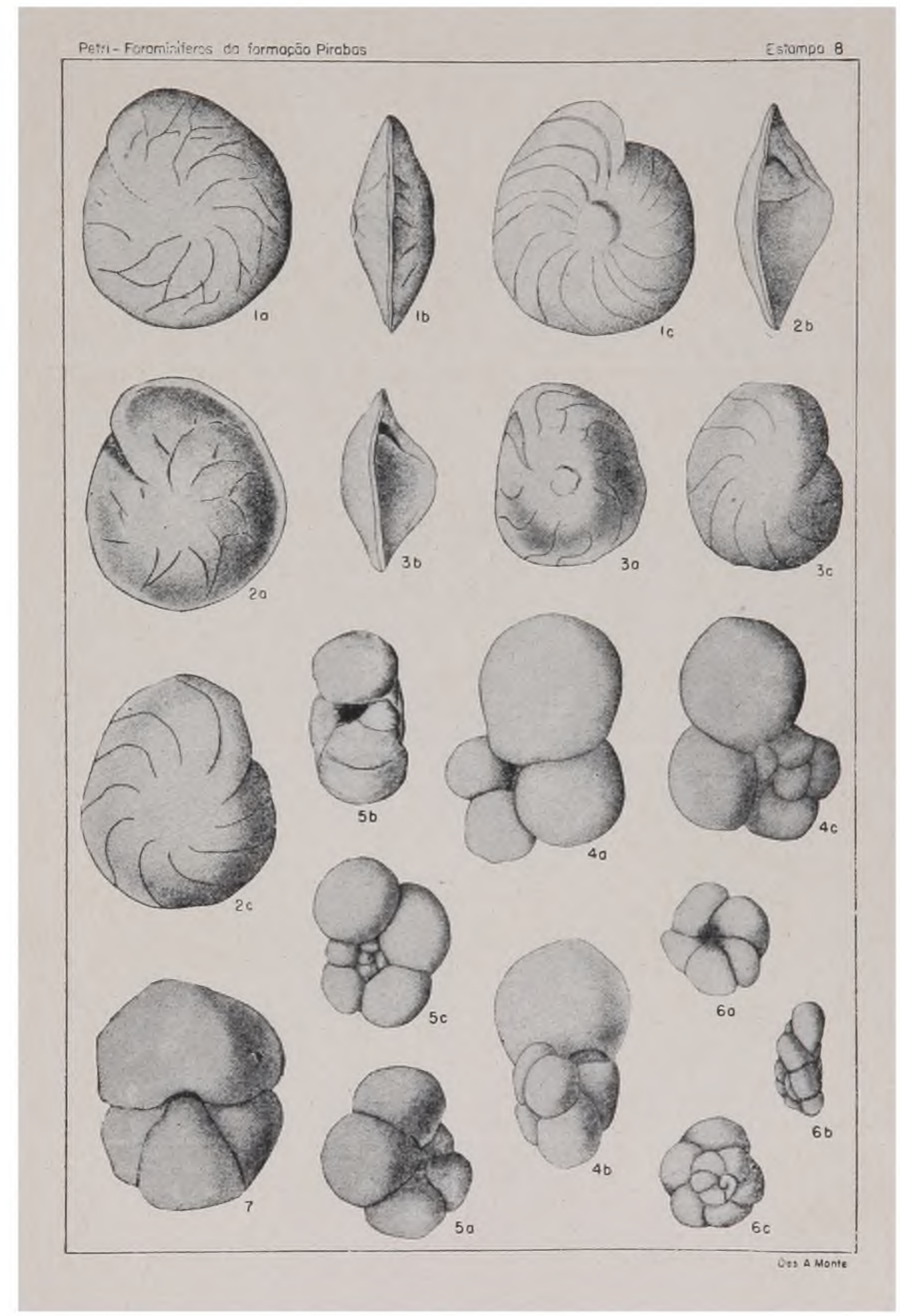




\section{ESTAMPA 9}

Fig̣s. 1 a $\mathrm{c}-$ Globorotalia cf. menardii (d'Orbigny) $-42 \mathrm{x}-$ Urindeua (2)

Figs. 2 a c - Cibicides pirabensis Petri, sp. nov. - Exemplar jovem $-85 \mathrm{x}-$ Japerica (10)

Figs. 3 a c - Idem - Exemplar adulto $-85 x-$ Japerica (10)

Figs. 4 a c - C. pirabensis? $-85 \mathrm{x}-$ Pedrinha (6)

Figs. 5 a c - C. lobatulus (Walker e Jacob) - $85 \mathrm{x}$ - Japerica (10)

Figs. 6 a c $-C$. pseudoungerianus (Cushman) $-85 \mathrm{x}-$ Japerica (10)

Figs. 7 a c - Cibicidina paraensis Petri, sp. nov. $-85 \mathrm{x}-$ Japerica (10) 


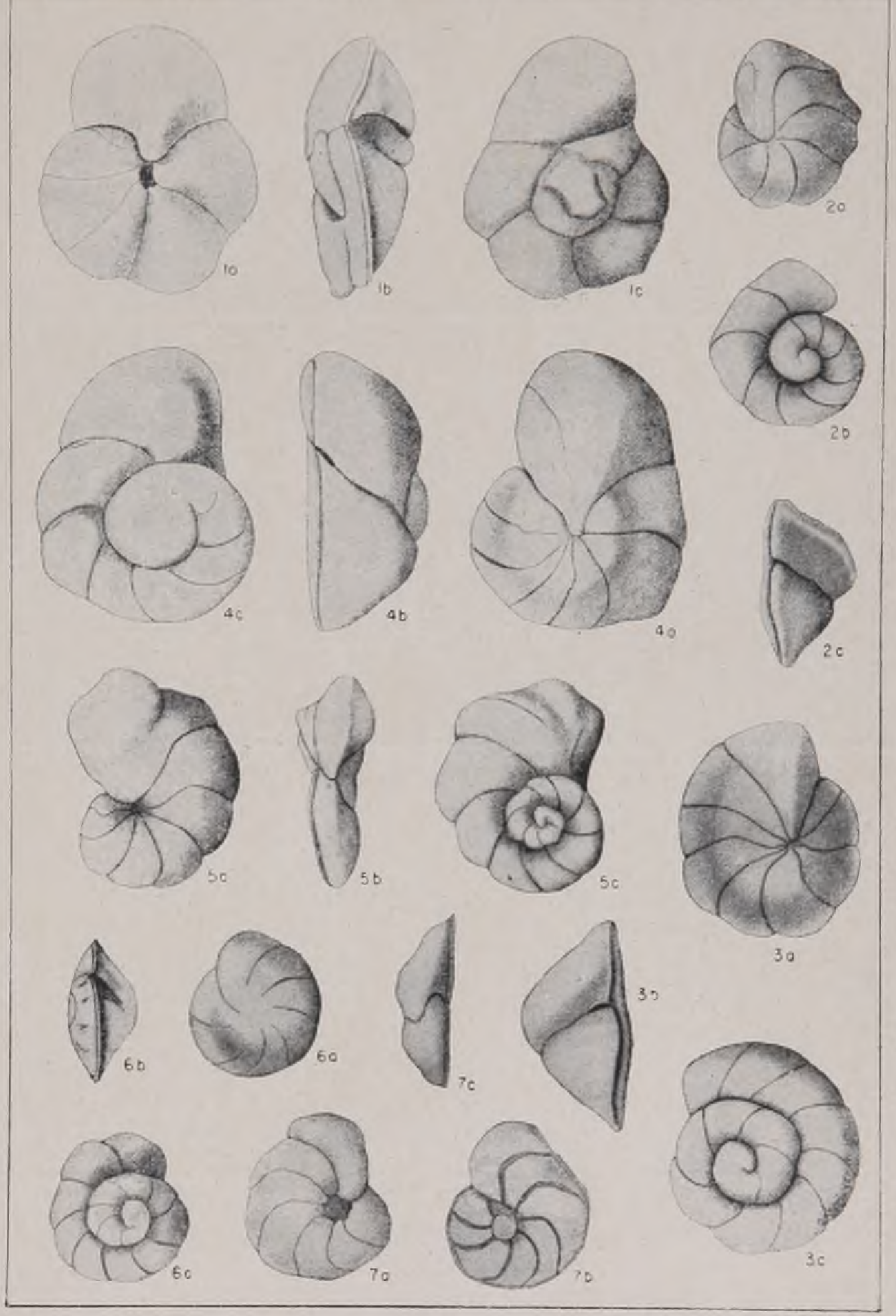



IMPRIMIU :

INDÚSTRIA GRÁFICA SIQUEIRA S/A RUA AUGUSTA, 235 - SĀO PAULO

ENC. 6784 